DOE/NV/11508-09

UC-703

\title{
A FIELD-SCALE DEMONSTRATION OF AIR SPARGING TO REMEDIATE TRITIATED FLUIDS
}

prepared by

Charles E. Russell, David R. Gillespie, Samuel L. Hokett, and James D. Donithan

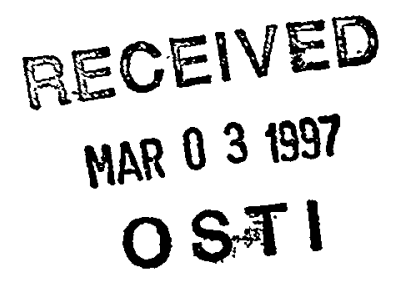

submitted to

Nevada Operations Office

U.S. Department of Energy

September 1996
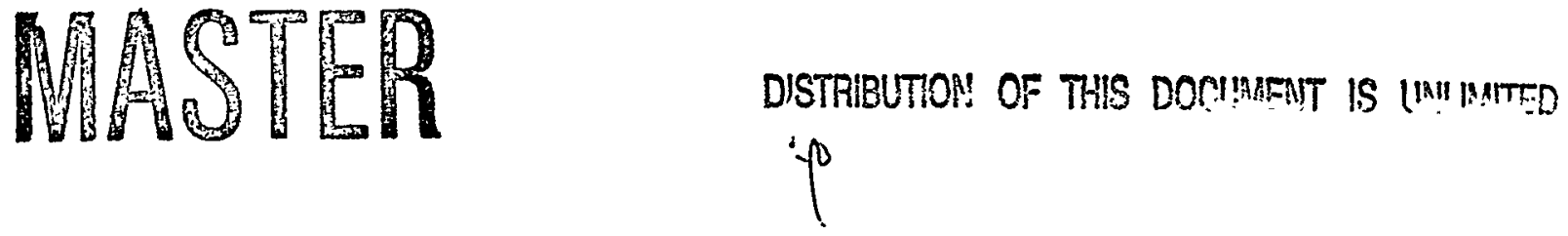

Publication \#45142 


\section{DISCLAIMER}

Portions of this document may be illegible in electronic image products. Images are produced from the best available original document. 


\title{
A FIELD-SCALE DEMONSTRATION OF AIR SPARGING TO REMEDIATE TRITIATED FLUIDS
}

\author{
prepared by \\ Charles E. Russell \\ David R. Gillespie \\ Samuel L. Hokett \\ James D. Donithan \\ Water Resources Center \\ Desert Research Institute \\ University and Community College System of Nevada
}

Publication No. 45142

submitted to

Nevada Operations Office

U.S. Department of Energy

Las Vegas, Nevada

August 1996

The work upon which this report is based was supported by the U.S. Department of Energy under Contract \#DE-AC08-95NV11508. 


\begin{abstract}
Two pilot field-scale studies were conducted during the period of May 24 to July 22, 1996, to evaluate the potential of air sparging to remediate tritiated fluids. Previous analytical solutions to the rate of tritium removal were evaluated and compared to the experimental results. The analytical solution of Craig and Gordon (1965) that describes isotopic fractionation of an evaporating body of water appears to most accurately describe the process, versus the more limited isotopic exchange equation of Slattery and Ingraham (1994) and the mass transfer equation of Wilson (1995) and Fordham (1994), which are accurate only at moderate to high humidities and do not describe the tritium enrichment process that would occur at low humidities.

The results of the two experiments demonstrated that air sparging of tritium is a viable process in the field. Tritium removal rates of 60 percent were reported during the first experiment and 66 percent for the second experiment. Comparison to previous laboratory work revealed that rates could have been improved by starting with higher concentrations, utilizing smaller bubbles, and longer bubble path lengths.

Risks associated with the pilot study were greater the closer one worked to the experiment with a maximum increase in the Lifetime Excess Total Risk per Unit Uptake of $2.4 \times 10^{-5}$. Conduct of this experiment at locations with much higher activities of tritium would significantly increase the associated risk.
\end{abstract}




\section{CONTENTS}

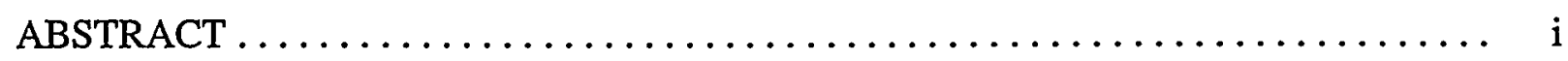

FIGURES $\ldots \ldots \ldots \ldots \ldots \ldots \ldots \ldots \ldots \ldots \ldots \ldots \ldots \ldots \ldots \ldots \ldots \ldots \ldots$

TABLES $\ldots \ldots \ldots \ldots \ldots \ldots \ldots \ldots \ldots \ldots \ldots \ldots \ldots \ldots \ldots \ldots \ldots \ldots \ldots$

INTRODUCTION $\ldots \ldots \ldots \ldots \ldots \ldots \ldots \ldots \ldots \ldots \ldots \ldots \ldots \ldots \ldots \ldots \ldots \ldots \ldots$

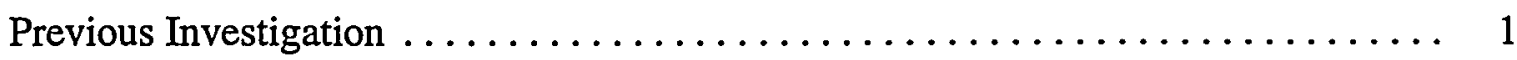

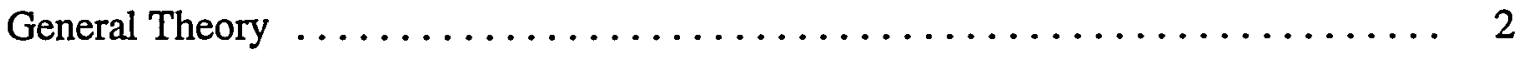

Objective of Study $\ldots \ldots \ldots \ldots \ldots \ldots \ldots \ldots \ldots \ldots \ldots \ldots \ldots \ldots \ldots \ldots \ldots$

METHODOLOGY $\ldots \ldots \ldots \ldots \ldots \ldots \ldots \ldots \ldots \ldots \ldots \ldots \ldots \ldots \ldots \ldots \ldots$

Meteorological Monitoring $\ldots \ldots \ldots \ldots \ldots \ldots \ldots \ldots \ldots \ldots \ldots \ldots \ldots \ldots$

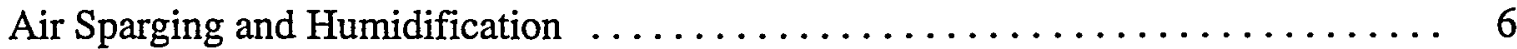

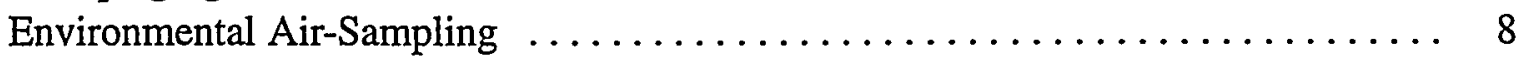

Isotopic Analyses $\ldots \ldots \ldots \ldots \ldots \ldots \ldots \ldots \ldots \ldots \ldots \ldots \ldots \ldots \ldots \ldots \ldots$

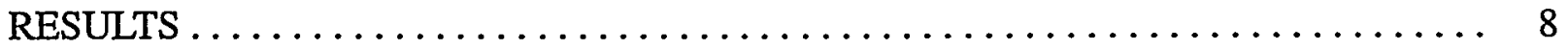

Meteorological Conditions of the Experiments ................ 8

Initial Conditions, Temperature, Airflow, and Humidity of the

Changes in Tritium Activity and Stable Isotopic Ratios . . . . . . . . . . . . 9

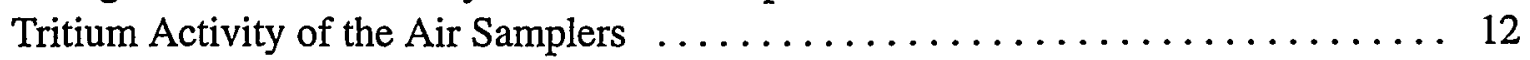

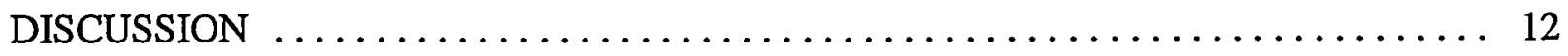

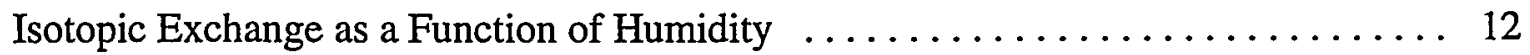

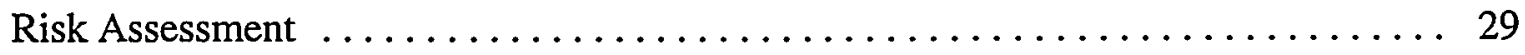

Extrapolation of Results to Sumps at ER-20-5 ................ 32

CONCLUSIONS $\ldots \ldots \ldots \ldots \ldots \ldots \ldots \ldots \ldots \ldots \ldots \ldots \ldots \ldots \ldots \ldots \ldots \ldots$

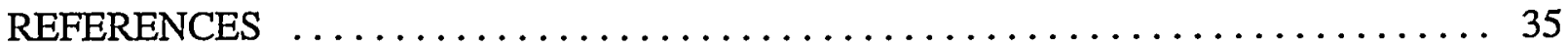




\section{FIGURES}

1. Isotopic composition of an evaporating body of water relative to the fraction of water remaining (initial isotopic composition of water is $-36 \% 0 \mathrm{DD}$ and of

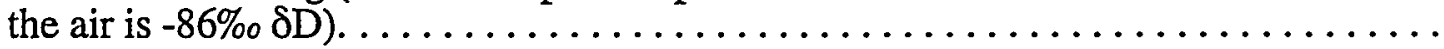

2. Isotopic composition of an evaporating body of water relative to the fraction of water remaining (initial isotopic composition of water is $913,000 \%$ $\delta \mathrm{D}$

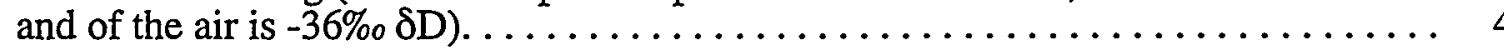

3. Schematic of Cambric tritium evaporative experiment. $\ldots \ldots \ldots \ldots \ldots \ldots \ldots$

4. Change in tritium concentration versus time - experiment one (May 23 to June 24, 1996).

5. Isotopic evolution of the tritiated fluid during the course of experiment one (May 23 to June 24, 1996).

6. Change in tritium concentration versus time - experiment two (June 28 to July 22, 1996).

7. Isotopic evolution of the tritiated fluid during the course of experiment two (June 28 to July 22, 1996).

8a. Percent of time wind originated from a given azimuth during the first week of experiment one (May 24 to May 31, 1996).

8b. Average wind speed $(\mathrm{m} / \mathrm{s})$ as a function of azimuth wind originated during the first week of experiment one (May 24 to May 31, 1996).

8c. Tritium concentration as a function of azimuth at $30.5 \mathrm{~m}$ from the experimental tank during the first week of experiment one (May 24 to May 31, 1996).

8d. Tritium concentration as a function of azimuth at $6.1 \mathrm{~m}$ from the experimental tank during the first week of experiment one (May 24 to May 31,1996 ). . . . . . 13

9a. Percent of time wind originated from a given azimuth during the second week of experiment one (May 31 to June 7, 1996).

9b. Average wind speed $(\mathrm{m} / \mathrm{s})$ as a function of azimuth wind originated during the second week of experiment one (May 31 to June 7, 1996).

9c. Tritium concentration as a function of azimuth at $30.5 \mathrm{~m}$ from the experimental tank during the second week of experiment one (May 31 to June 7,1996$) \ldots \ldots \ldots 14$

9d. Tritium concentration as a function of azimuth at $6.1 \mathrm{~m}$ from the experimental tank during the second week of experiment one (May 31 to June 7,1996$) \ldots \ldots \ldots 14$

10a. Percent of time wind originated from a given azimuth during the third week of experiment one (June 7 to June 14, 1996). 
10b. Average wind speed $(\mathrm{m} / \mathrm{s})$ as a function of azimuth wind originated during the third week of experiment one (June 7 to June 14, 1996).

10c. Tritium concentration as a function of azimuth at $30.5 \mathrm{~m}$ from the experimental tank during the third week of experiment one (June 7 to June 14, 1996) . . . . . . 15

10d. Tritium concentration as a function of azimuth at $6.1 \mathrm{~m}$ from the experimental tank during the third week of experiment one (June 7 to June 14, 1996). . . . . . 15

11a. Percent of time wind originated from a given azimuth during the final 10 days of experiment one (June 14 to June 24,1996$) \ldots \ldots \ldots \ldots \ldots \ldots \ldots \ldots \ldots$

11b. Average wind speed $(\mathrm{m} / \mathrm{s})$ as a function of azimuth wind originated during the final 10 days of experiment one (June 14 to June 24,1996 ). . . . . . . . . . . 16

11c. Tritium concentration as a function of azimuth at $30.5 \mathrm{~m}$ from the experimental tank during the final 10 days of experiment one (June 14 to June 24,1996$) \ldots \ldots \ldots 16$

11d. Tritium concentration as a function of azimuth at $6.1 \mathrm{~m}$ from the experimental tank during the final 10 days of experiment one (June 14 to June 24, 1996)...... 16

12a. Percent of time wind originated from a given azimuth during the first week of experiment two (June 28 to July 5, 1996).

12b. Average wind speed $(\mathrm{m} / \mathrm{s})$ as a function of azimuth wind originated during the first week of experiment two (June 28 to July 5,1996 ).

12c. Tritium concentration as a function of azimuth at $30.5 \mathrm{~m}$ from the experimental tank during the first week of experiment two (June 28 to July 5,1996 ).

12d. Tritium concentration as a function of azimuth at $6.1 \mathrm{~m}$ from the experimental tank during the first week of experiment two (June 28 to July 5, 1996).

13a. Percent of time wind originated from a given azimuth during the second week of experiment two (July 5 to July 12, 1996).

13b. Average wind speed $(\mathrm{m} / \mathrm{s})$ as a function of azimuth wind originated during the second week of experiment two (July 5 to July 12, 1996).

13c. Tritium concentration as a function of azimuth at $30.5 \mathrm{~m}$ from the experimental tank during the second week of experiment two (July 5 to July 12,1996$). \ldots \ldots \ldots$

13d. Tritium concentration as a function of azimuth at $6.1 \mathrm{~m}$ from the experimental tank during the second week of experiment two (July 5 to July 12, 1996). . . . . . .

14a. Percent of time wind originated from a given azimuth during the third week of experiment two (July 12 to July 19, 1996).

14b. Average wind speed $(\mathrm{m} / \mathrm{s})$ as a function of azimuth wind originated during the third week of experiment two (July 12 to July 19,1996 ). . 
14c. Tritium concentration as a function of azimuth at $30.5 \mathrm{~m}$ from the experimental tank during the third week of experiment two (July 12 to July 19, 1996).

14d. Tritium concentration as a function of azimuth at $6.1 \mathrm{~m}$ from the experimental tank during the third week of experiment two (July 12 to July 19, 1996).

15a. Percent of time wind originated from a given azimuth during the final three days of experiment two (July 19 to July 22,1996$) \ldots \ldots \ldots \ldots \ldots \ldots \ldots \ldots \ldots \ldots$

15b. Average wind speed $(\mathrm{m} / \mathrm{s})$ as a function of azimuth wind originated during the final three days of experiment two (July 19 to July 22, 1996). .

15c. Tritium concentration as a function of azimuth at $30.5 \mathrm{~m}$ from the experimental tank during the final three days of experiment two (July 19 to July 22, 1996).

15d. Tritium concentration as a function of azimuth at $6.1 \mathrm{~m}$ from the experimental tank during the final three days of experiment two (July 19 to July 22, 1996).

16. The change in tritium concentration as measured and modeled (Slattery and Ingraham, 1994) during the course of the first experiment.

17. The change in tritium concentration as measured and modeled (Slattery and Ingraham, 1994) during the course of the second experiment.

18. Fraction of water remaining within the experimental tank during the course of experiment one.

19. Fraction of water remaining within the experimental tank during the course

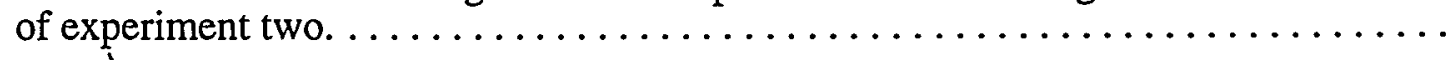

20. Ambient relative humidity encountered during the course of experiment one. . . . 24

21. The change in tritium concentration as measured and modeled (utilizing Craig and Gordon, 1965) during the course of experiment one..................

22. Observed versus modeled results (utilizing Craig and Gordon, 1965) for deuterium enrichment during the course of experiment one. ................... 26

23. Observed versus modeled results (utilizing Craig and Gordon, 1965) for oxygen-18 enrichment during the course of experiment one.

24. The change in tritium concentration as measured and modeled (utilizing Craig and Gordon, 1965) during the course of experiment two...................

25. Observed versus modeled results (utilizing Craig and Gordon, 1965) for deuterium

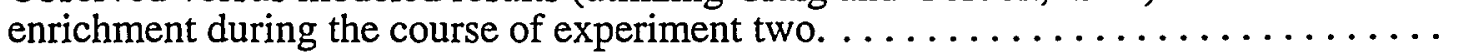

26. Observed versus modeled results (utilizing Craig and Gordon, 1965) for oxygen-18 enrichment during the course of experiment two. 
27. Dimensionless rates of change in tritium activity versus fraction of water remaining for five hypothetical experiments (identical to experiment two) with the sole variation between the experiments being differing levels of relative humidity.

28. Rates of change in tritium mass within the experimental tank versus time for five hypothetical experiments (identical to experiment two) with the sole variation between the experiments being differing levels of relative humidity. . . . . . . . . . 30

29. Change in tritium mass versus time for sump \#7 at ER-20-5 as a function of differing levels of relative humidity.

\section{TABLES}

1. Equipment Used to Monitor Ambient Conditions. ................ 5

2. Continuously Monitored Parameters of the Air-sparging and Humidification

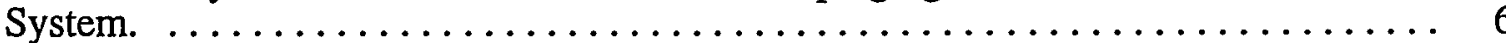

3. Meteorological Conditions Incurred during the Two Experiments. $\ldots \ldots \ldots \ldots$

4. Values Utilized to Solve Craig and Gordon (1965) for Experiments One and Two. . . 22

5. Performance of Air-Sparging Methodology during Experiment One and Two. ..... 25

6. Tritium Activities in the Air Approximately $1 \mathrm{~m}$ above the Surface of the Tritiated Fluid in the Tank 


\section{INTRODUCTION}

This report documents the application of air sparging to the remediation of tritiated fluids at a field site. The Nevada Test Site (NTS), located in Nye County, Nevada, has been utilized for hundreds of underground nuclear tests. The detonation of the nuclear devices has deposited many curies of tritium in the subsurface. Some of the tritium has contaminated the groundwater. Drilling investigations associated with the Department of Energy's Environmental Restoration Program has brought tritiated fluids to the surface where it is stored in lined sumps. In addition, many other DOE facilities have tritiated water in surface impoundments. The rapid and economical removal of tritium is desired to minimize risks associated with the storage, handling, and or accidental release of the tritiated fluid.

\section{Previous Investigation}

Several laboratory experiments have evaluated the exchange of tritium from the aqueous to the vapor phase. Initial experiments, conducted by Friedman, Machta and Soller (1962), consisted of monitoring the isotopic composition of a water droplet suspended in a humidified air stream. The results of this experiment verified earlier theoretical calculations by Bolin (1958) and Kinzer and Gunn (1951) which predicted large isotopic changes can occur between water and vapor without a change in the water mass.

Horton et al. (1971) demonstrated that tritiated water is preferentially lost over non-tritiated water when exposed to an atmosphere with a relative humidity greater than 8 percent.

Slattery and Ingraham (1993) utilized two experimental methods to evaluate the transfer of tritium between liquid and vapor using stable isotopes and tritium activities under controlled conditions. The first set of experiments utilized passive vapor exchange between two isolated bodies of water in a closed system with initial tritium concentrations ranging from 304,000 picocuries per liter ( $\mathrm{pCi} / \mathrm{L}$ ) to background (less than $30 \mathrm{pCi} / \mathrm{L}$ ). The purpose of the experiments was to evaluate the effect of temperature, surface areas, volumes, and atmospheric turbulence on the rate of exchange. A second set of experiments utilized turbulent injection of a tritium-depleted water vapor into a tritiated body of fluid. The rates of exchange of tritium between the tritiated fluid and the vapor were evaluated as a function of bubble path length.

The results of the experiment were used to demonstrate that vapor can, even in quiescent conditions, transport tritium from enriched to depleted reservoirs. The process is driven by isotopic exchange until the liquids reach isotopic equilibrium. The experiments demonstrated that a fluid could undergo simultaneous enrichment of deuterium and oxygen- 18 while experiencing depletion of tritium. The experiments yielded the observations that the surface area to volume ratio, temperature, and degree of atmospheric turbulence or air flow rate are directly proportional to the rate of exchange of tritium from the water to the vapor phase. Bubble experiments indicated that isotopic exchange is rapid and occurs over short $(20 \mathrm{~cm})$ bubble path lengths. Exchange rates for stable isotopes were found to vary from 0.09 to $0.19 \mathrm{~cm}$ per day at $22^{\circ} \mathrm{C}$ and 0.86 to $0.92 \mathrm{~cm}$ per day at $52^{\circ} \mathrm{C}$. The exchange rate has units of velocity and has been interpreted as a piston velocity when scaled to a wind speed or as a coefficient of stickiness. 
A second study, conducted by Fordham (1994), further validated the concept. Variables evaluated during bubble-mediated exchange included initial tritium activity, air flow rate, water $\mathrm{pH}$, degree of saturation of the air stream, and methods of aeration. The final conclusion mirrored the earlier study with the addition that removal rates were the same for non-humidified versus humidified air. A third study by Wilson (1995) reconstructed Fordham's (1994) experimental apparatus and utilized it to evaluate the affects of the degree of saturation of the air stream, the bubble size, and temperature on the rate of tritium removal. Conclusions were that the efficiency of the process increased with increasing temperature, greater initial concentration, a decrease in bubble size, and path length, and decreased relative humidity. A cost analysis of tritium remediation, in terms of power consumption utilizing an existing power grid and infrastructure, was conducted for small quantities of tritiated fluid. Both Wilson (1995) and Fordham (1994) concluded that the mechanism for transfer of tritium from liquid to vapor was mass transfer.

\section{General Theory}

The following section on isotopic exchange was taken directly from Slattery and Ingraham (1994). The transfer of water vapor to and from a body of water is a dynamic process that, under conditions of 100 percent humidity, allows for isotopic exchange without a net loss or gain of water mass. The rate of evaporation is limited by the diffusion of water vapor through a quiescent layer of air near the surface (Craig and Gordon, 1965; Dorsey, 1968). The Craig and Gordon model utilizes two layers to describe this process. The stagnant layer immediately adjacent to the water surface is saturated with water vapor; molecular diffusion is the dominant transport mechanism within this layer. The region above this quiescent layer has the same water content as the bulk atmosphere where the transport is via advection. The flux of gas through each boundary layer is given by the equation:

$$
\mathrm{Q}=\mathrm{k} \Delta \mathrm{C}
$$

where $\mathrm{Q}$ is the flux of gas through a boundary, $\Delta \mathrm{C}$ is the concentration gradient across a particular layer, and $\mathrm{k}$ is the corresponding exchange constant. The exchange constant has been shown to be approximated at 100 percent relative humidity (Slattery and Ingraham, 1994) by the ratio of the density of water vapor (in $g$ per cubic meter) to the density of water at a given temperature. A mass balance on the volume of water and an airstream passing adjacent to the surface or bubbled through the water yields:

$$
\mathrm{V}_{\mathrm{L}} \mathrm{dC}_{\mathrm{L}} / \mathrm{dt}=\mathrm{FC}_{\mathrm{in}}-\mathrm{FC}_{\text {out }}
$$

where $\mathrm{V}_{\mathrm{L}}$ and $\mathrm{C}_{\mathrm{L}}$ are the volume (in liters) and activity of the tritiated water $(\mathrm{pCi} / \mathrm{L}), \mathrm{F}$ is the air flow rate (liters per day), $C_{i n}$ and $C_{\text {out }}$ are the activity of the input and output air streams (pCi/L), and $t$ is time (days). At atmospheric equilibrium, the equality

$$
\mathrm{C}_{\text {out }}=\mathrm{kC}_{\mathrm{L}}
$$

exists (this condition has been rapidly reached in laboratory experiments) and yields 


$$
\mathrm{dC}_{\mathrm{L}} / \mathrm{dt}+\mathrm{kF} / \mathrm{V}_{\mathrm{L}}=\mathrm{FC}_{\text {in }}
$$

Equation (4) is a linear first order differential equation applicable if the change in isotopic composition of the liquid phase over time is known. The solution to Equation (4) is:

$$
\ln \left(\left(C_{L}(t)-C_{\text {in }}\right) /\left(C_{o}-C_{\text {in }}\right)\right)=-F k t / V_{L}
$$

This equation can be reworked to solve for $\mathrm{C}_{\mathrm{L}}(\mathrm{t})$ :

$$
\mathrm{C}_{\mathrm{L}}(\mathrm{t})=\mathrm{C}_{\mathrm{in}}+\left(\mathrm{C}_{\mathrm{o}}-\mathrm{C}_{\mathrm{in}}\right) \mathrm{e}^{-\left(\mathrm{Fk} t / \mathrm{V}_{\mathrm{L}}\right)}
$$

Equation (6) can be used to model the isotopic composition of a body of water undergoing exchange (at 100 percent humidity) at any time $t$ if the original isotopic composition, temperature, and volume of the water, the isotopic composition of the air stream being injected into the water, the air flow rate, and the exchange constant are known.

Alternatively, if a body of water is undergoing evaporation, then isotopic fractionation as the body of water evaporates becomes the controlling mechanism. Craig and Gordon's (1965) solution for evaporation into humid environments has often been used to model the evaporation of liquids into partially saturated atmospheres. A typical example is given in Figure 1 (Gonfiantini, 1987). This example demonstrates the trend in the isotopic composition of an evaporating body of water relative to the fraction of water remaining as a function of varying humidity. The initial isotopic composition of the water in Figure 1 is $-36 \% o \delta \mathrm{D}$ and that of the atmosphere is $-86 \%$ o $\delta$. It is readily apparent that as the atmosphere becomes more humid, the final isotopic composition is enriched to a lesser

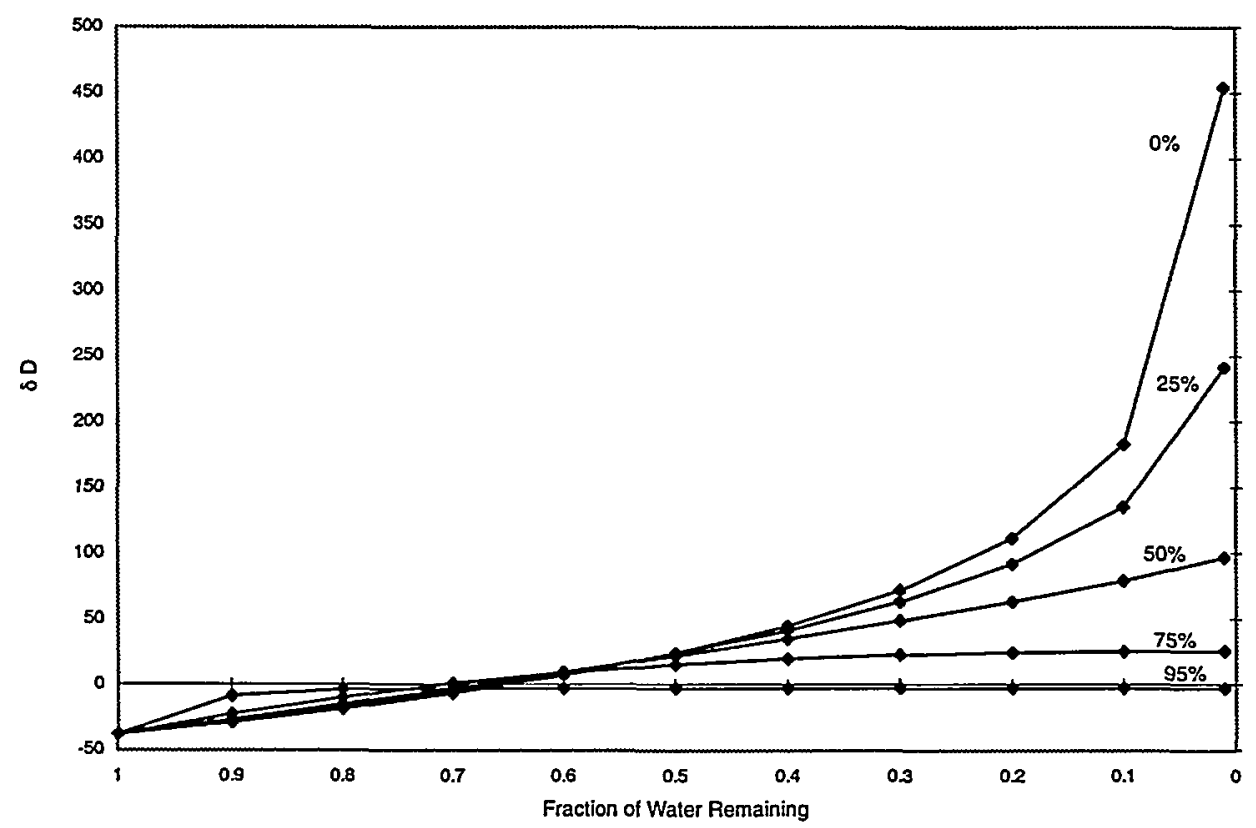

Figure 1. Isotopic composition of an evaporating body of water relative to the fraction of water remaining (initial isotopic composition of water is $-36 \% \circ \delta \mathrm{D}$ and of the air is $-86 \% \circ \delta \mathrm{D}$ ). 
degree. Figure 2 demonstrates the isotopic composition of an evaporating body of water relative to the fraction of water remaining as a function of varying humidity, similar to Figure 1 except for a large difference in deuterium values between the water $(913,000 \% o \delta D)$ and the air $(-86 \% \circ \delta D)$. Although the $\delta \mathrm{D}$ value is unrealistic under natural conditions, it serves to illustrate that at moderate to high humidity and a large per mil difference in deuterium, the stable isotopic composition of the water will begin to trend towards the lighter isotopic composition of the air, rather than become enriched as in the previous example. This situation is exactly analogous to the large differences in activities between the atmosphere and an evaporating reservoir of tritiated water.

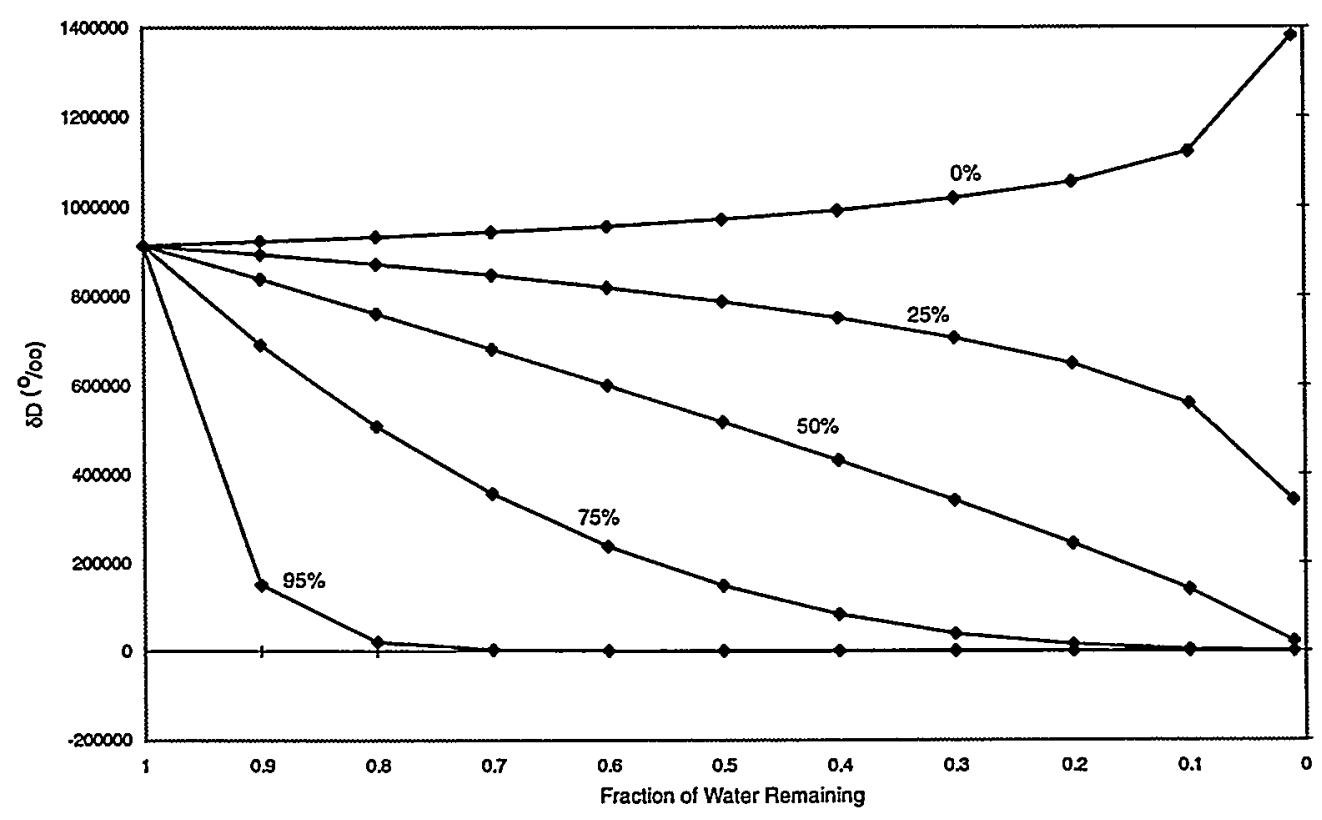

Figure 2. Isotopic composition of an evaporating body of water relative to the fraction of water remaining (initial isotopic composition of water is $913,000 \% \circ \delta \mathrm{D}$ and of the air is $-36 \% \circ \delta \mathrm{D}$ ).

The Craig and Gordon (1965) model consists of the following:

$$
\delta=\left(\delta_{0}-\mathrm{A} / \mathrm{B}\right) \mathrm{f}^{\mathrm{B}}+\mathrm{A} / \mathrm{B}
$$

where

$$
\begin{aligned}
& \mathrm{A}=\frac{\mathrm{h} \delta_{\alpha}+\Delta \varepsilon+\varepsilon / \alpha}{1-\mathrm{h}+\Delta \varepsilon} \\
& \mathrm{B}=\frac{\mathrm{h}-\Delta \varepsilon-\varepsilon / \alpha}{1-\mathrm{h}-\Delta \varepsilon}
\end{aligned}
$$

$\delta$ is the del composition of the evaporating body of water, $\delta_{0}$ is the initial del composition of the water, $f$ is the fraction of water remaining, $h$ is the relative humidity, $\Delta \varepsilon$ is the kinetic enrichment 
factor, $\varepsilon$ is the equilibrium enrichment factor, and $\alpha$ is the equilibrium fractionation factor. $\delta$ is defined as the ratio of the rare versus the more common isotope in a sample, divided by that same ratio in a standard and subtracted by one.

Wilson (1995) and Fordham (1994).proposed mass transfer as the mechanism that controls the removal of tritium from the aqueous to the vapor phase. This simple model, while adequate for describing tritium removal at moderate to high humidities and high activities, is inadequate for describing the enrichment of tritium in the vapor phase at low levels of relative humidity as observed by Horton et al. (1971) and presented in Figure 2. These inadequacies negated the use of this solution on the results of this study

\section{Objective of Study}

The objective of this study was to evaluate the aforementioned analytical solutions that describe the depletion of tritium from a reservoir to the atmosphere during two successive experiments conducted under field conditions. An assessment was made of how successfully the analytical solutions predicted the depletion of tritium in the tank. If unsuccessful, an analysis of underlying causes was made and the governing equations were modified, if necessary.

A second objective was to assess the health and safety issues of exposing nearby workers to a continuous stream of tritiated vapor. Successful completion of this task resulted in the determination of the excess lifetime risk to an individual working at a distance of $6.1 \mathrm{~m}$ and 30.5 $\mathrm{m}$ from the experiment for extended periods of times. A final objective was to determine the major logistical requirements of fielding a large-scale tritium remediation project in a remote area, such as the NTS.

\section{METHODOLOGY}

\section{Meteorological Monitoring}

The monitoring of environmental conditions during experiments was crucial to the successful evaluation of the methodology under ambient conditions. Parameters monitored consisted of ambient temperature, relative humidity, wind speed, wind direction, and quantity of precipitation. Table 1 contains a listing of all equipment used to monitor ambient conditions. Ambient environmental conditions were sampled every minute and averaged every hour.

TABLE 1. EQUIPMENT USED TO MONITOR AMBIENT CONDITIONS.

\begin{tabular}{ll}
\hline Parameter & Manufacturer and Probe Type \\
\hline Temperature & Campbell CS500 \\
Relative Humidity & Campbell CS500 \\
Precipitation & Tipping Bucket \\
Wind Speed & W.M. Young Anemometer \\
Wind Direction & W.M. Young Anemometer \\
\hline
\end{tabular}




\section{Air Sparging and Humidification}

Tritiated water for the field study was obtained from well RNM-2 in Frenchman Flat, Nevada Test Site, Nye County, Nevada. Well RNM-2 was drilled to induce the migration of tritium deposited during the detonation of an underground nuclear test conducted approximately $91 \mathrm{~m}$ distant from the well. Approximately $36,000 \mathrm{~L}$ of water at an activity of $160,000 \mathrm{pCi} / \mathrm{L}$ were pumped from the well into a metal tank containing $98 \mathrm{~m}$ of $5.08-\mathrm{cm}$ PVC pipe lying on the bottom of the tank. The PVC pipe had been previously drilled with 1280 holes of $0.63-\mathrm{cm}$ diameter. The $5.08-\mathrm{cm}$ PVC pipe was connected to two $20-\mathrm{cm}$ PVC manifolds, which were in turn connected to a single $30-\mathrm{cm}$ PVC pipe (Figure 3). The purpose of the PVC piping was to serve as a duct and diffuser to introduce a humidified stream of air into the bottom of the tank containing the tritiated water.

The air injected into the PVC duct and diffuser was supplied by a Gardner-Denver Model 11CDL31 Cycloblower, an air-screw type blower, capable of producing $153.4 \mathrm{~m}^{3}$ of air per minute at a pressure of $1.2 \mathrm{~atm}$. The blower was operated between 700 and 800 RPM and continuously monitored via a magnetic switch on the rotor of the blower. This produced a fairly consistent air stream of between 52 and $59 \mathrm{~m}^{3}$ per minute, corrected to $25^{\circ} \mathrm{C}$ and one atmosphere of pressure. Into this air stream was injected an atomized spray of water that totaled $41 \mathrm{~kg}$ of water per hour. The source of this water was well $5 \mathrm{~b}$ in Frenchman Flat. This tritium-free water was stored in a 75,800 L (20,000 gallons) tank located 25 m northeast of the tritiated tank. The spray of water was produced using a Hygromatik model EMF-B air fogger and was intended to humidify the air stream to between 85 and 100 percent. The humidified air stream was directed into the $30-\mathrm{cm}$ PVC pipe at a pressure of $0.16 \mathrm{~atm}$, where it eventually was discharged, via the diffusers, into the tritiated tank of water. The tritiated vapor was discharged either through a $30-\mathrm{cm}$ vent on the side of the tank or through the top of the tank when it was uncovered.

Various components of the air sparging and humidification system were monitored to evaluate their performance. These components and their purpose are listed in Table 2. Parameters associated with the air-sparging process were sampled once every ten seconds and averaged every minute.

TABLE 2. CONTINUOUSLY MONITORED PARAMETERS OF THE AIR SPARGING AND HUMIDIFICATION SYSTEM.

\begin{tabular}{ll}
\hline Monitored Parameter & Monitoring Equipment \\
\hline Air-flow rate & Dybec Air-flow Meter \\
Air temperature after the blower and before humidification & Campbell Thermistor \\
In-line air pressure & Omega Air Transducer \\
Water level in the tritiated tank & Steven's Pulse Generator \\
Water temperature of tank & Campbell Thermistor \\
Temperature of air exhaust above the tritiated water & Campbell Thermistor \\
Humidity of air exhaust above the tritiated water & Hygromatik Humidifier \\
\hline
\end{tabular}




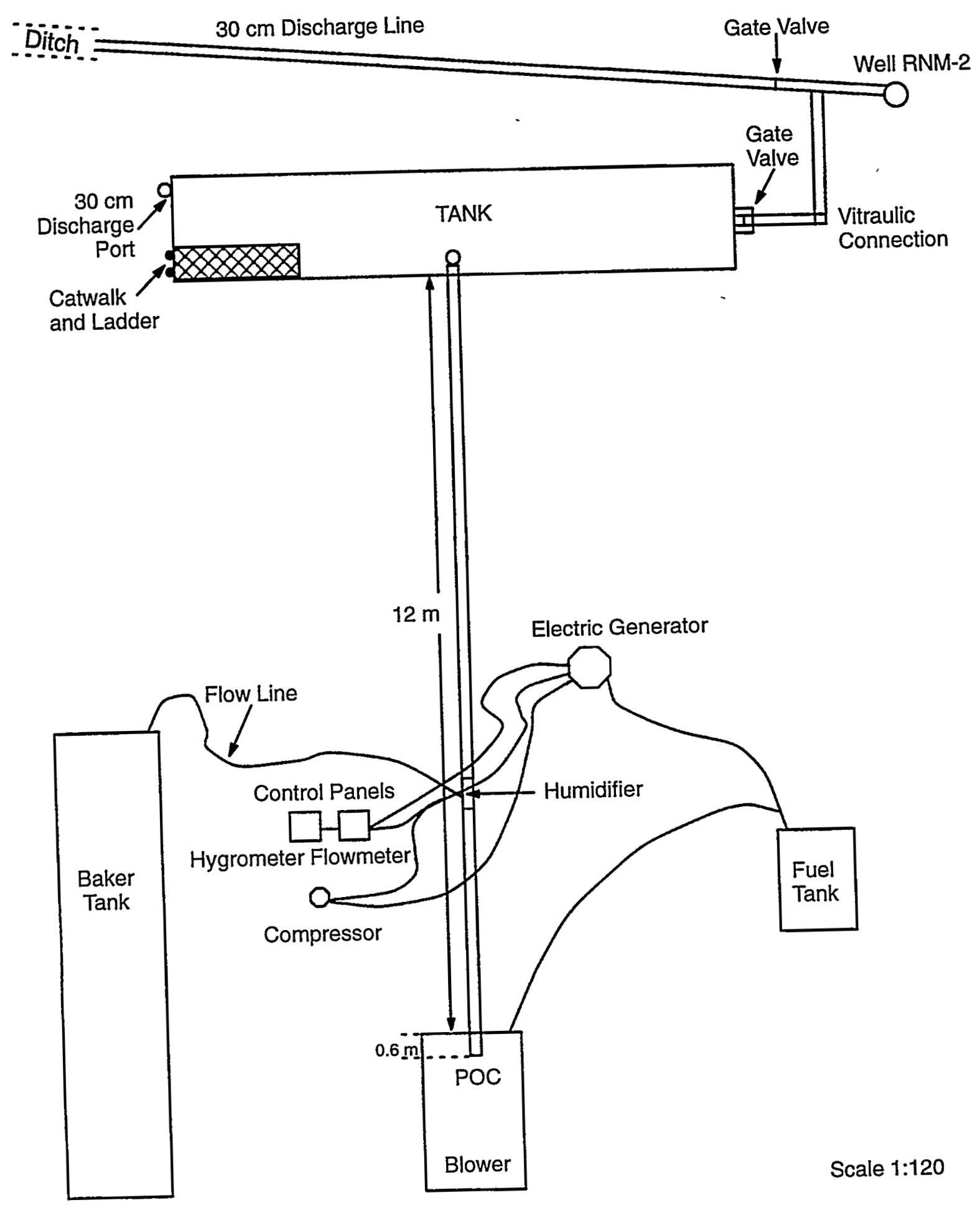

Figure 3. Schematic of Cambric tritium evaporative experiment. 


\section{Environmental Air Sampling}

Environmental air sampling was accomplished according to EPA (1979). A molecular sieve containing a desiccant was placed in a box at the sample location. An electrically powered air pump forced approximately $37 \mathrm{ml}$ per min through the molecular sieve. The molecular sieves were replaced every seven days and taken to the laboratory where extraction of the water from the desiccant was accomplished by heating the sieve to $350^{\circ} \mathrm{C}$, using helium as the carrier gas, and condensing the water in a cold-trap.

\section{Isotopic Analyses}

Water collected from the tritium tank was analyzed for tritium activity on a daily basis (EPA, 1975), stable isotopes of oxygen (Dugan et al., 1985) and hydrogen (Kendall and Coplen, 1985) every other day, and water quality parameters at the end of the experiments. The results from these analyses were used to determine if the water, once the experiment was completed, could be discharged to the land surface. Water collected from the environmental air samplers were enriched and analyzed for tritium (EPA, 1975).

\section{RESULTS}

\section{Meteorological Conditions of the Experiments}

A statistical description of the meteorological conditions during experiments 1 and 2 are contained in Table 3. Experiment one, initiated on May 23, 1996, was conducted continuously until June 24, 1996. The first experiment was initiated during a cool wet period characterized by low temperatures and some precipitation. The latter half of this experiment was hot and dry. Winds would rise up out of the south, on nearly a daily basis, and blow from approximately noon until 3:00 or 4:00 p.m. The second experiment was initiated on June 28, 1996, and operated until July 22, 1996. Conditions during the second experiment were hot, windy, and dry for the entire period.

TABLE 3. METEOROLOGICAL CONDITIONS INCURRED DURING THE TWO EXPERIMENTS.

\begin{tabular}{lcccc}
\hline \multicolumn{1}{c}{ Parameter } & Mean & Std. Dev. & Max. & Min. \\
\hline Experiment 1 & & & & \\
Air Temperature (C) & 25.2 & 8.6 & 39.9 & 7.2 \\
Relative Humidity (\%) & 17.9 & 16.6 & 95.1 & 4.1 \\
Wind Speed (m/s) & 2.6 & 2.2 & 10.7 & 0.0 \\
Direction Wind Originated From & 197 & 91.9 & $\mathrm{n} / \mathrm{a}$ & $\mathrm{n} / \mathrm{a}$ \\
Precipitation (total cm) & 0.18 & & & \\
Experiment 2 & & & & \\
Air Temperature (C) & 29.9 & 7.1 & 40.8 & 10.3 \\
Relative Humidity (\%) & 20.1 & 11.4 & 60.7 & 5.0 \\
Wind Speed (m/s) & 2.3 & 2.0 & 10.3 & 0.0 \\
Direction Wind Originated From & 189 & 96.4 & $\mathrm{n} / \mathrm{a}$ & $\mathrm{n} / \mathrm{a}$ \\
Precipitation (total cm) & 0.0 & & & \\
\hline
\end{tabular}




\section{Initial Conditions, Temperature, Airflow, and Humidity of the Tritiated Tank during the Experiments}

The initial conditions for experiment one consisted of a large metal tank approximately 13.5 $\mathrm{m}$ long, $2.2 \mathrm{~m}$ wide, and $2.44 \mathrm{~m}$ tall, partially filled with $36,000 \mathrm{~L}$ of water. The fluid in the tank had an initial tritium activity of $156,900 \pm 1060 \mathrm{pCi} / \mathrm{L}(49,000 \pm 331$ tritium units (TU)), and a stable isotopic signature of $-10.2 \% \circ \delta^{18} \mathrm{O}$ and $-95 \% \circ \delta \mathrm{D}$. A tarp covered approximately 95 percent of the tank to force the exhaust into a ventilation pipe from which air samples could be taken. Into this tank was injected 53,000 L of air per minute for 30.2 days. Ambient air was pulled into the blower and then humidified by injecting variable rates of water to reach a minimum 85 percent relative humidity. The tritium activity of the water used to humidify the air stream was $193 \pm 315$ $\mathrm{pCi} / \mathrm{L}(60 \pm 98 \mathrm{TU})$. This water had a stable isotopic signature of $-9.7 \% \circ \delta^{18} \mathrm{O}$ and $-94 \% o \delta \mathrm{D}$. The water supply tank utilized to humidify the air stream was completely covered by a tarp to inhibit exchange with tritium exhaust discharging from the experimental tank and to inhibit evaporation. Ambient air surrounding the experiment had a tritium activity that was a function of background and exhaust emitted from the experiment. The greatest amount of tritium activity detected in the vicinity of the intake manifold of the blower was $128 \mathrm{pCi}$ per cubic meter of air $(6,420 \mathrm{pCi} / \mathrm{L}$ for an aqueous vapor sample). Typical concentrations were $10 \mathrm{pCi}$ per cubic meter of air ( $480 \mathrm{pCi} / \mathrm{L}$ for an aqueous vapor sample). It is assumed that 90 percent of the water vapor entrained into the air injected into the tritium tank originated from the clean water tank and 10 percent was a mixture of background air and exhaust air. These assumptions result in an activity of $4.4 \mathrm{pCi}$ per cubic meter of air $(220 \mathrm{pCi} / \mathrm{L})$. The stable isotopic signature of the ambient air was $-26.6 \% o \delta^{18} \mathrm{O}$ and $-193 \%$ $\delta \mathrm{D}$.

The second experiment was conducted in the same tank as the first. Differences in the second experiment consisted of a larger initial volume of water $(38,919 \mathrm{~L})$ at a higher activity of tritium $219,000 \pm 2,620 \mathrm{pCi} / \mathrm{L}(68,430 \pm 819 \mathrm{TU})$. Air was injected into the tank at an average rate of 59,000 $\mathrm{L} / \mathrm{min}$ for a period of 21.36 days. The tarp was removed from the second experiment as condensation had formed on the underside of the tarp during the first experiment, impeding the removal of tritium from the water to the vapor phase.

\section{Changes in Tritium Activity and Stable Isotopic Ratios}

The change in tritium activity of the tritiated water within the tank during the first experiment is presented in Figure 4. The evolution of the stable isotopic signature of the tank is given in Figure 5. Examination of Figure 4 reveals an initial decline in tritium activity during the first four days of operation. The next ten days had relatively little change except for a spike in activity on Julian day 156. This spike was associated with a fivefold increase in error relative to surrounding analyses and is attributed to analytical error versus any real change in activity. Tritium activities began to decrease from Julian day 160 through the end of the experiment. The stable isotopic signature, as shown in Figure 5, increased steadily throughout the duration of the experiment.

The change in tritium activity of the tritiated water within the tank during the second experiment is presented in Figure 6. The evolution of the stable isotopic signature of the tank is given 


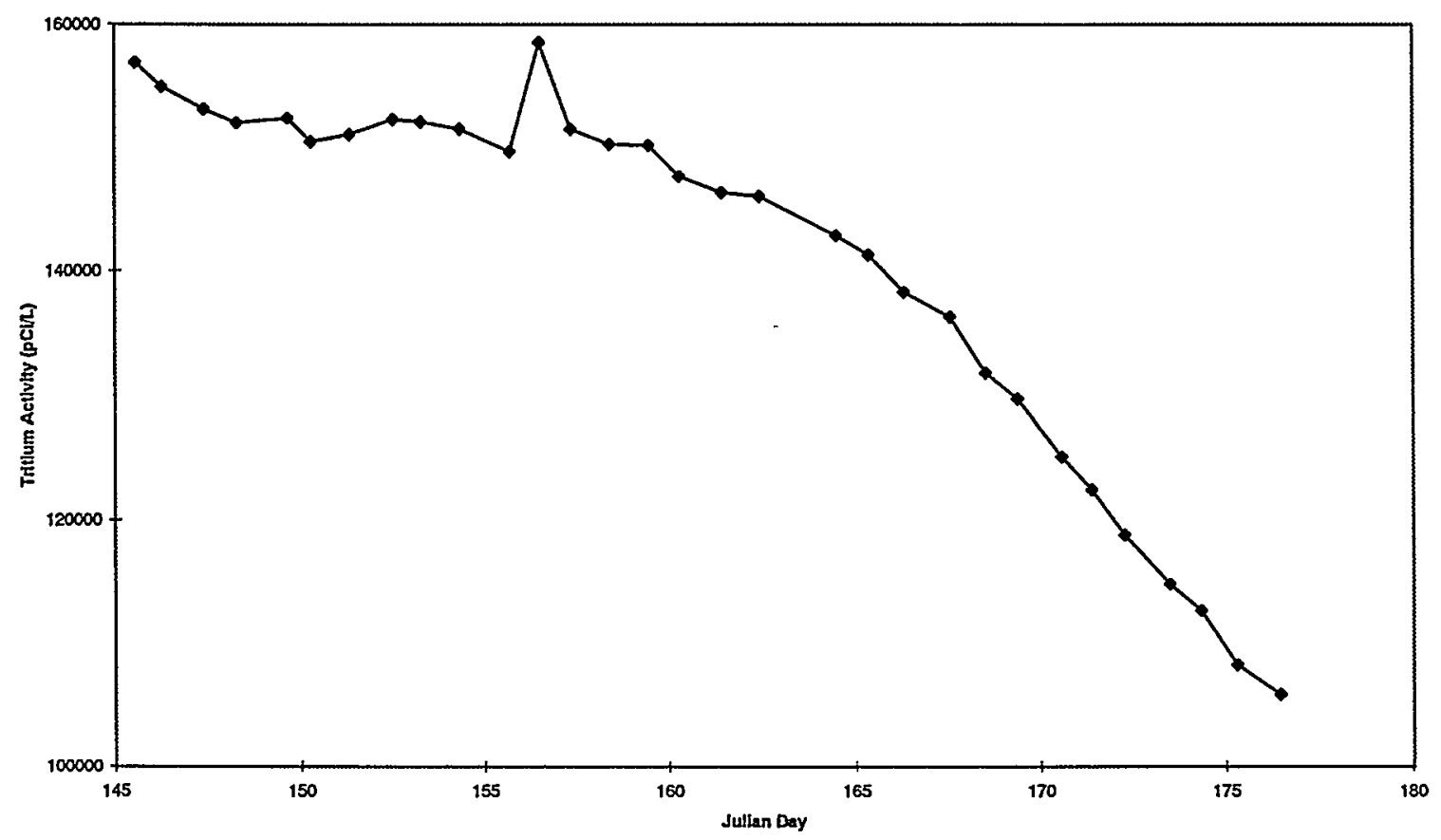

Figure 4. Change in tritium concentration versus time - experiment one (May 23 to June 24, 1996).

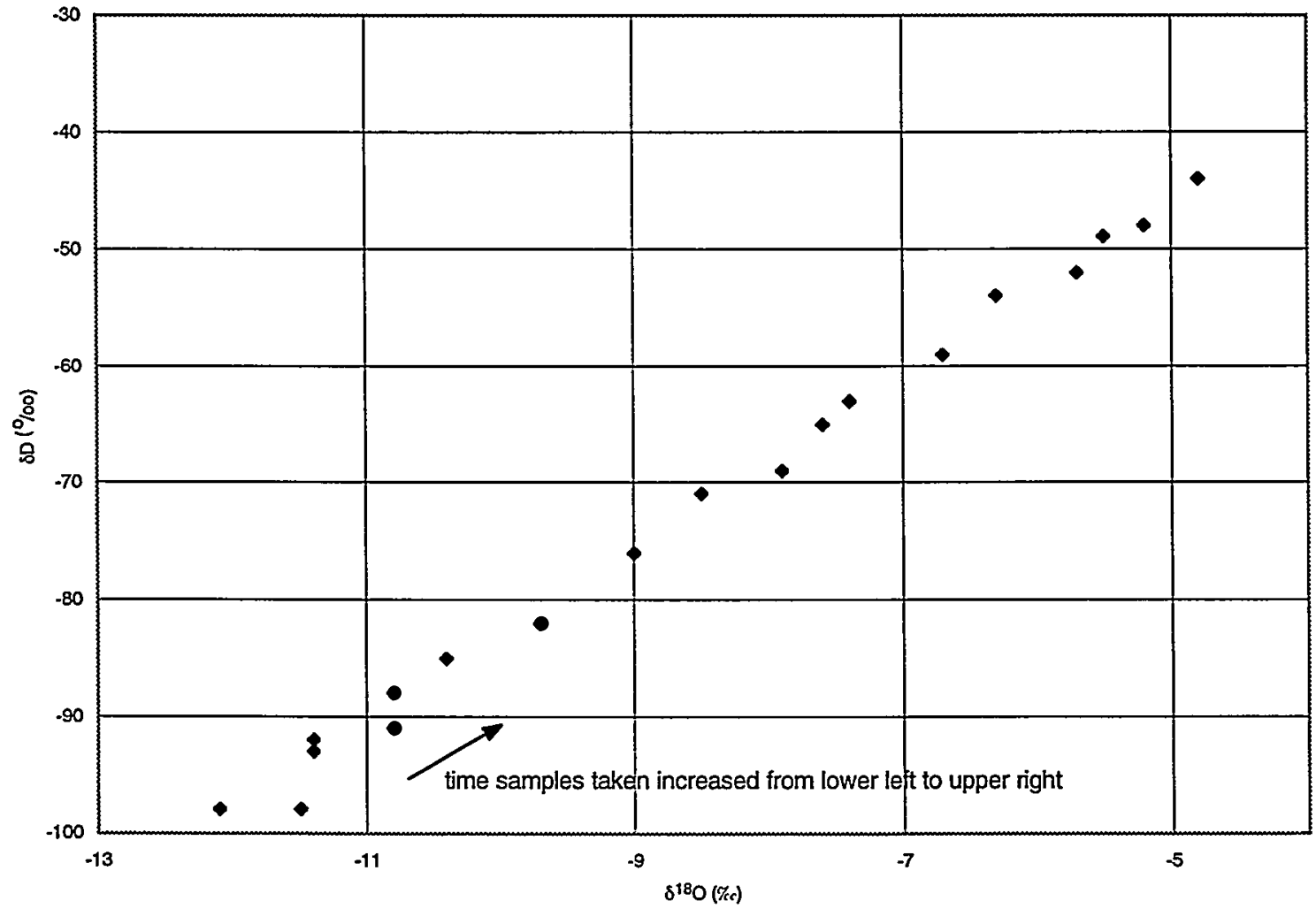

Figure 5. Isotopic evolution of the tritiated fluid during the course of experiment one (May 23 to June 24, 1996). 


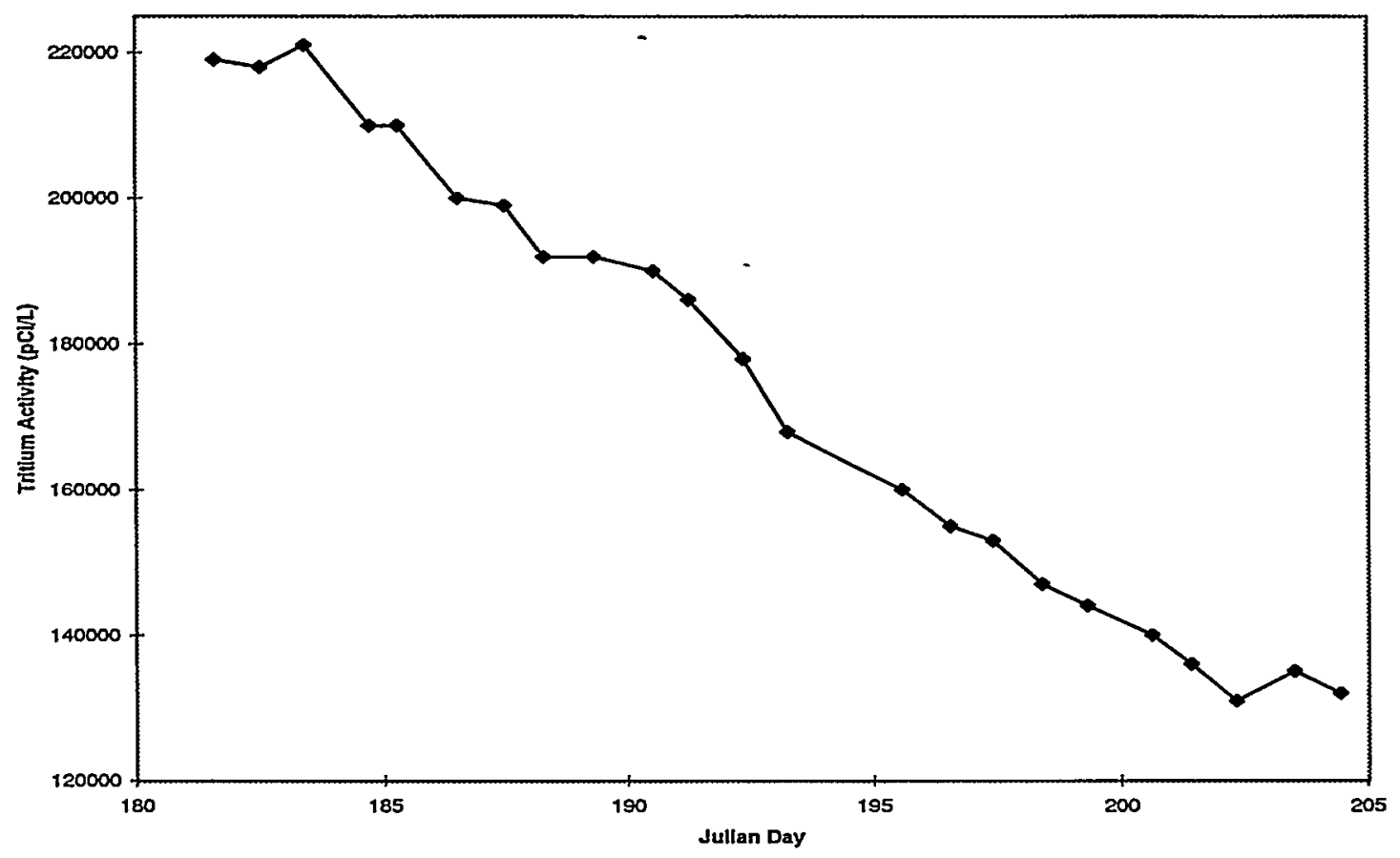

Figure 6. Change in tritium concentration versus time - experiment two (June 28 to July 22, 1996).

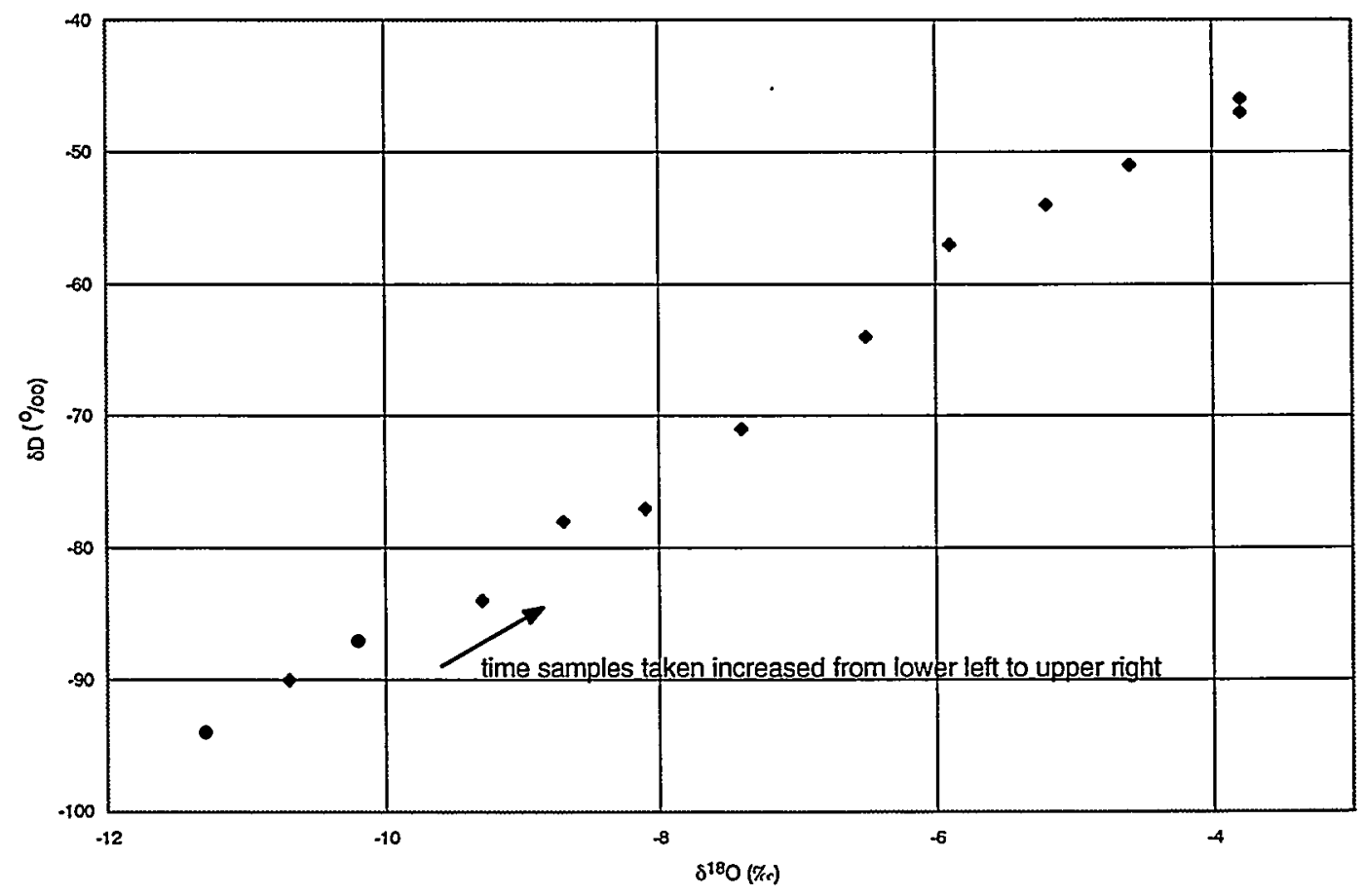

Figure 7. Isotopic evolution of the tritiated fluid during the course of experiment two (June 28 to July 22, 1996). 
in Figure 7. Examination of Figure 6 reveals a fairly steady to rising tritium activity for the first three days of operation of the second experiment. Tritium activities, beginning on Julian day 186, began to steadily decrease until the last two days of the experiment, at which time activities slightly increased. Stable isotopic signatures rose steadily, albeit at a slightly lesser rate, than experiment one.

\section{Tritium Activity of the Air Samplers}

Figures 8 through 15 are composite figures depicting: a) the frequency (percent of time), as a function of azimuth, from which the wind blew; b) the average speed of the wind $(\mathrm{m} / \mathrm{s})$, as a function of azimuth from which the wind originated; $c$ ) the tritium activity ( $\mathrm{pCi} / \mathrm{L}$ ) of the water vapor, as a function of azimuth, at a distance of $30.5 \mathrm{~m}$; and d) the tritium activity of the water vapor $(\mathrm{pCi} / \mathrm{L})$, as a function of azimuth, at a distance of $6.1 \mathrm{~m}$. The tritium activities are the concentration of the vapor corrected to a unit quantity of one liter $(\mathrm{pCi} / \mathrm{L})$. It must be remembered that at saturated conditions and an ambient temperature of $25^{\circ} \mathrm{C}$ a cubic meter of air contains only $23 \mathrm{gm}$ of water.

Examination of Figures 8 through 15 reveals that the wind was predominantly out of the south to southwest with maximum wind speeds invariably originating from the same directions. However, if one examines the tritium concentrations at $6.1 \mathrm{~m}$, the greatest activities are predominantly detected in the eastern air samplers. The greatest activities detected by the samplers located at $30.5 \mathrm{~m}$ were usually those located to the east of the experiment. The wind direction and wind strength are uncorrelated to the azimuth of the samplers with the highest tritium activities. The exhaust from the experiment was a dense moist plume that had a lower than ambient temperature. It is conjectured that this plume remained cohesive under relatively calm conditions. High winds would tend to mix the plume, creating conditions in which the tritiated vapor would be rapidly diluted. The samplers with the highest tritium concentration typically occur in the direction to which the lower velocity winds were blowing.

\section{DISCUSSION}

\section{Isotopic Exchange as a Function of Humidity}

Previous research has demonstrated that tritium may be isotopically exchanged under nonevaporative and evaporative conditions. Equation (6) (Slattery and Ingraham, 1994) was developed as a model of isotopic exchange under nonevaporative conditions. Equation (6) was, for the purpose of this study, discretized with respect to time (to handle varying flow rates (F) and operating times (t)). The discretized model was used to determine the change in tritium concentration within the tank, utilizing a rate constant of $0.000085 /$ day, as published in Slattery and Ingraham (1994), and the initial conditions discussed in the previous section. The results of this model for experiment one are given in Figure 16. Figure 17 contains the results of the model for experiment two.

Equation (6) clearly overestimates the amount of tritium being removed during both experiments. A number of factors contribute to this, however, one dominates. The mean ambient temperature during the first experiment was $25.2^{\circ} \mathrm{C}$, with a relative humidity of 17.9 percent. A 


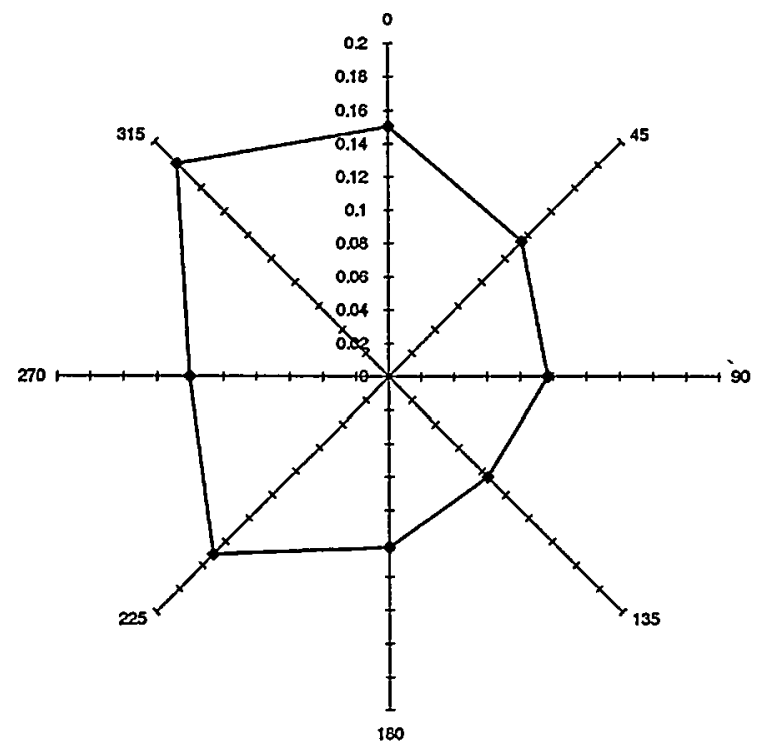

Figure 8a. Percent of time wind originated from a given azimuth during the first week of experiment one (May 24 to May 31, 1996).

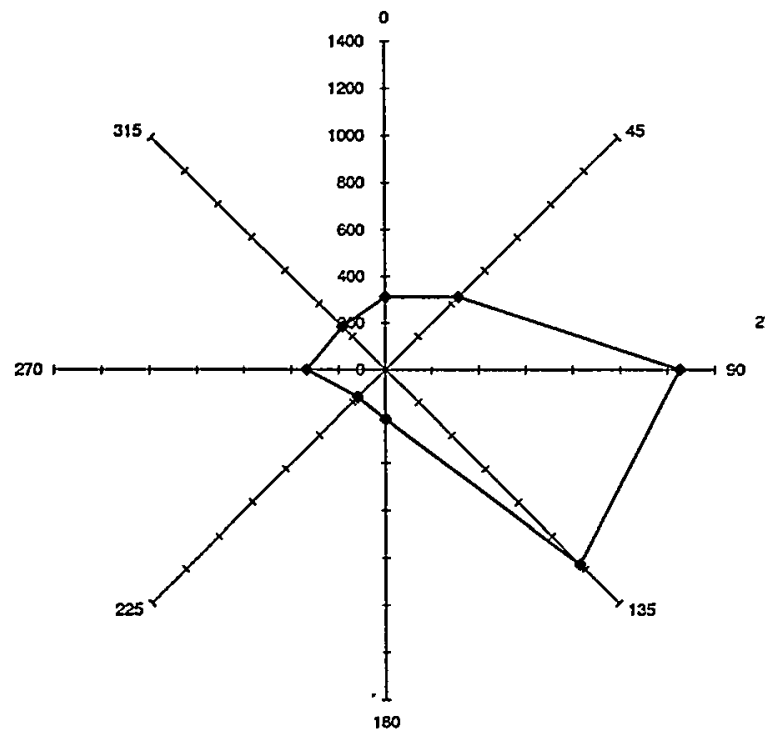

Figure 8c. Tritium concentration as a function of azimuth at $30.5 \mathrm{~m}$ from the experimental tank during the first week of experiment one (May 24 to May 31, 1996).

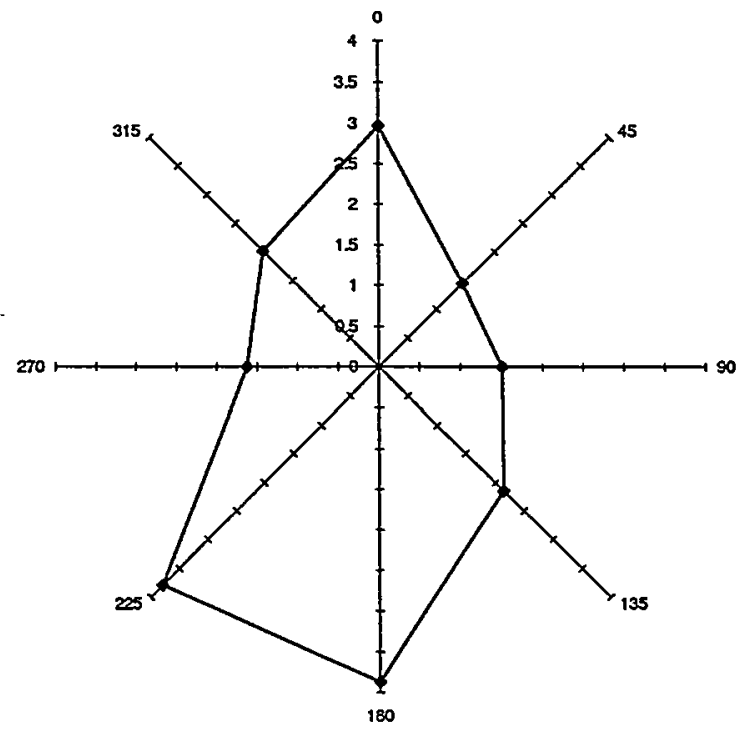

Figure $8 \mathrm{~b}$. Average wind speed $(\mathrm{m} / \mathrm{s})$ as a function of azimuth wind originated during the first week of experiment one (May 24 to May 31, 1996).

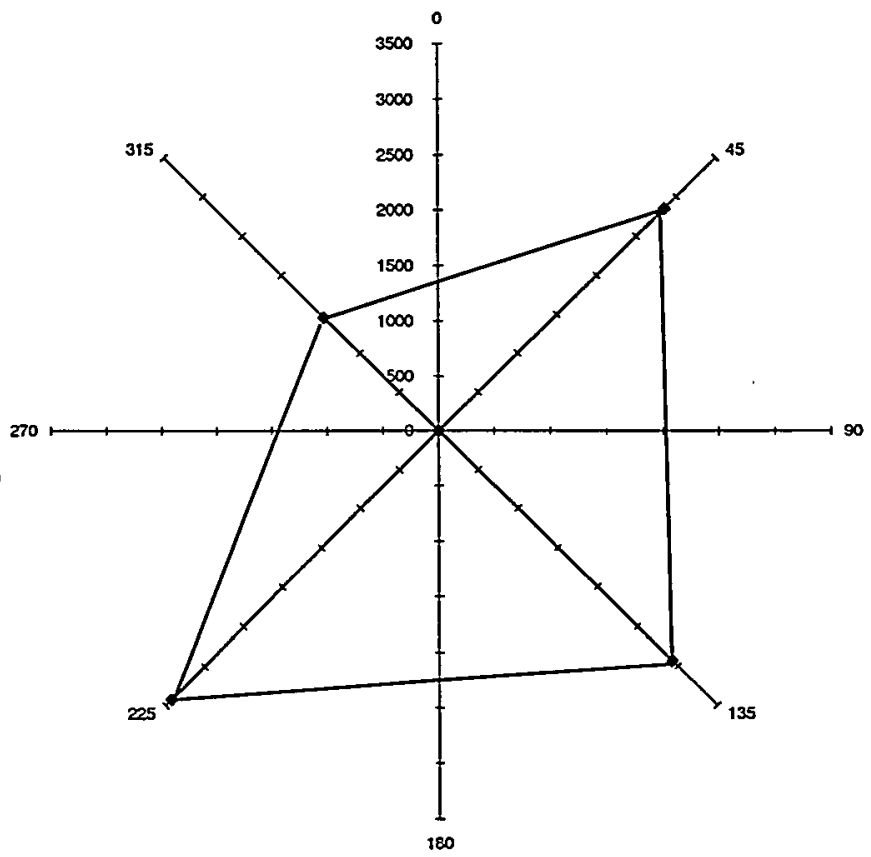

Figure 8d. Tritium concentration as a function of azimuth at $6.1 \mathrm{~m}$ from the experimental tank during the first week of experiment one (May 24 to May 31, 1996). 


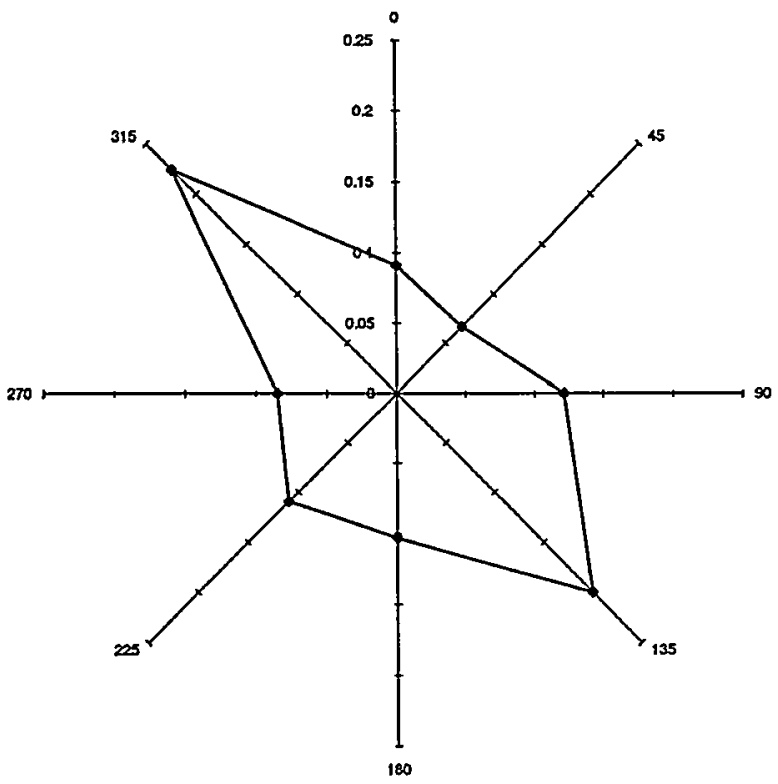

Figure 9a. Percent of time wind originated from a given azimuth during the second week of experiment one (May 31 to June 7, 1996).

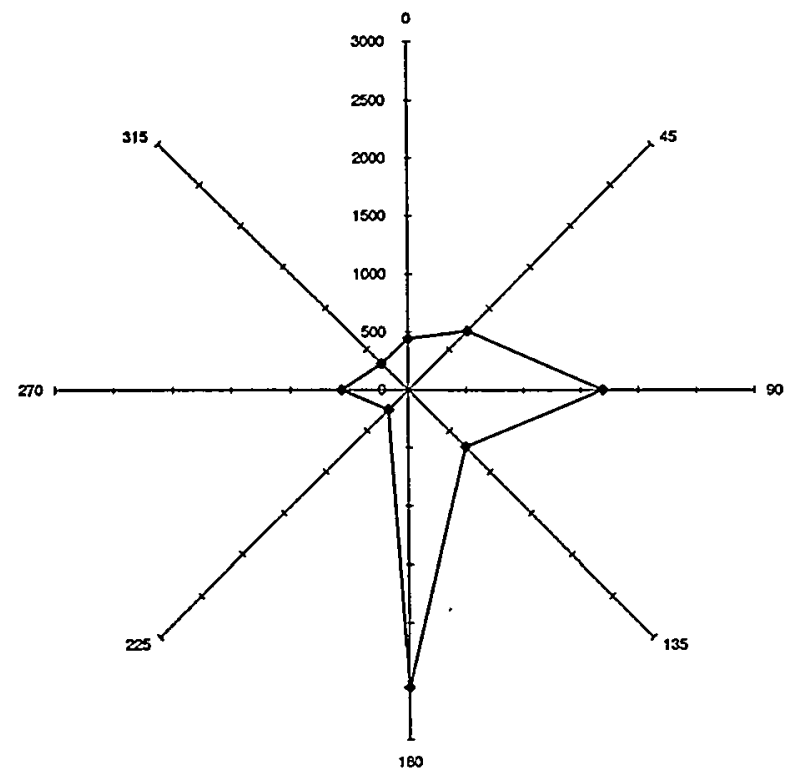

Figure 9c. Tritium concentration as a function of azimuth at $30.5 \mathrm{~m}$ from the experimental tank during the second week of experiment one (May 31 to June 7,1996 ).

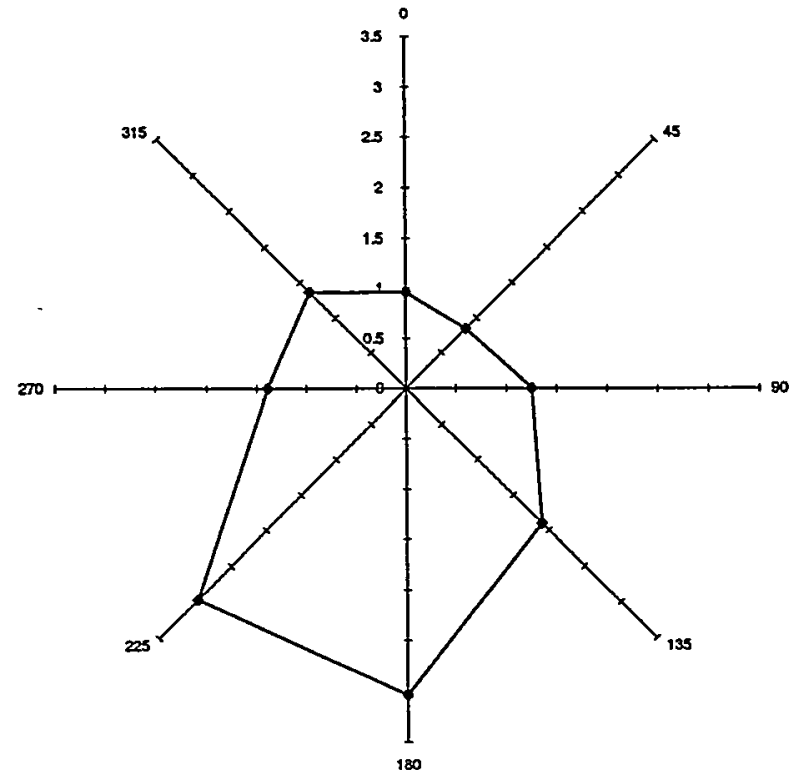

Figure $9 \mathrm{~b}$. Average wind speed $(\mathrm{m} / \mathrm{s})$ as a function of azimuth wind originated during the second week of experiment one (May 31 to June 7, 1996).

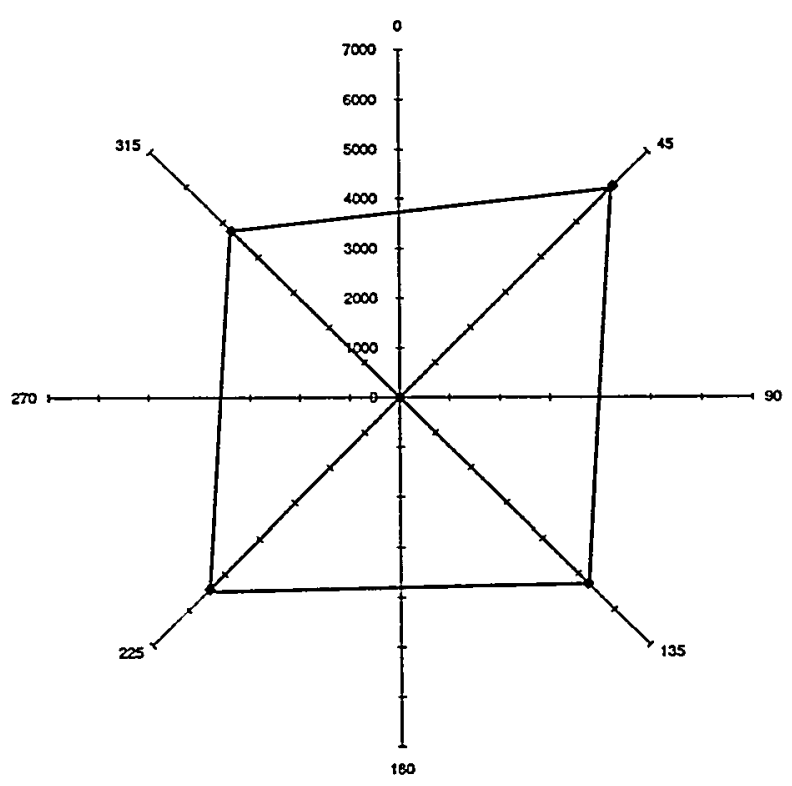

Figure 9d. Tritium concentration as a function of azimuth at $6.1 \mathrm{~m}$ from the experimental tank during the second week of experiment one (May 31 to June 7, 1996). 


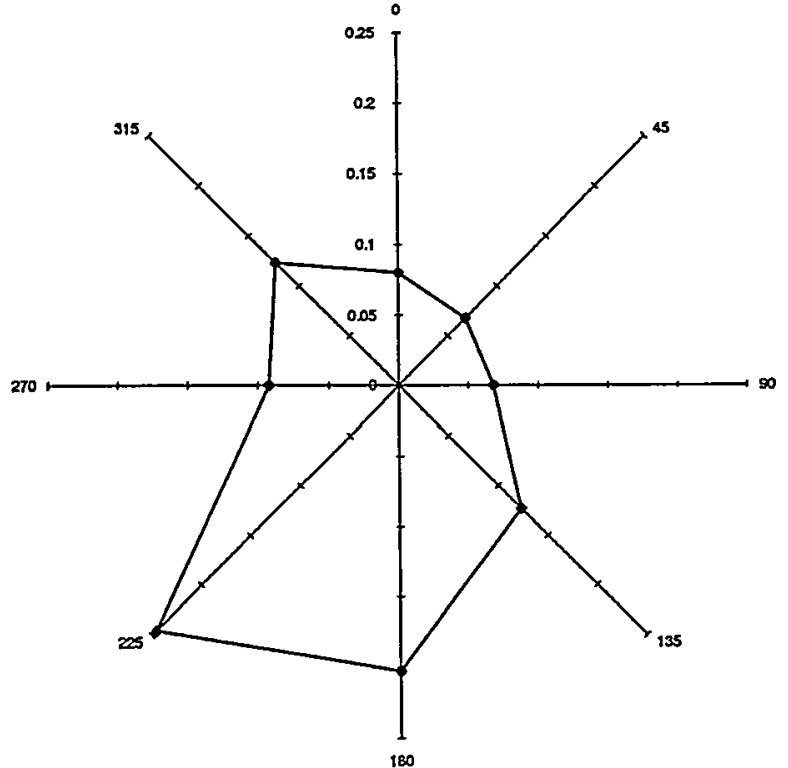

Figure 10a. Percent of time wind originated from a given azimuth during the third week of experiment one (June 7 to June 14, 1996).

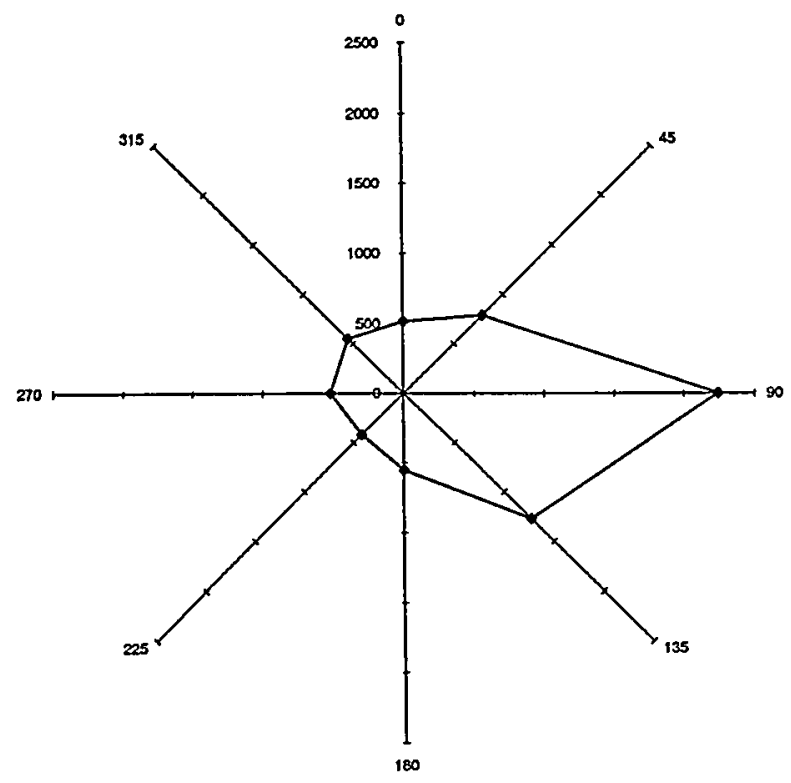

Figure 10c. Tritium concentration as a function of azimuth at $30.5 \mathrm{~m}$ from the experimental tank during the third week of experiment one (June 7 to June 14, 1996).

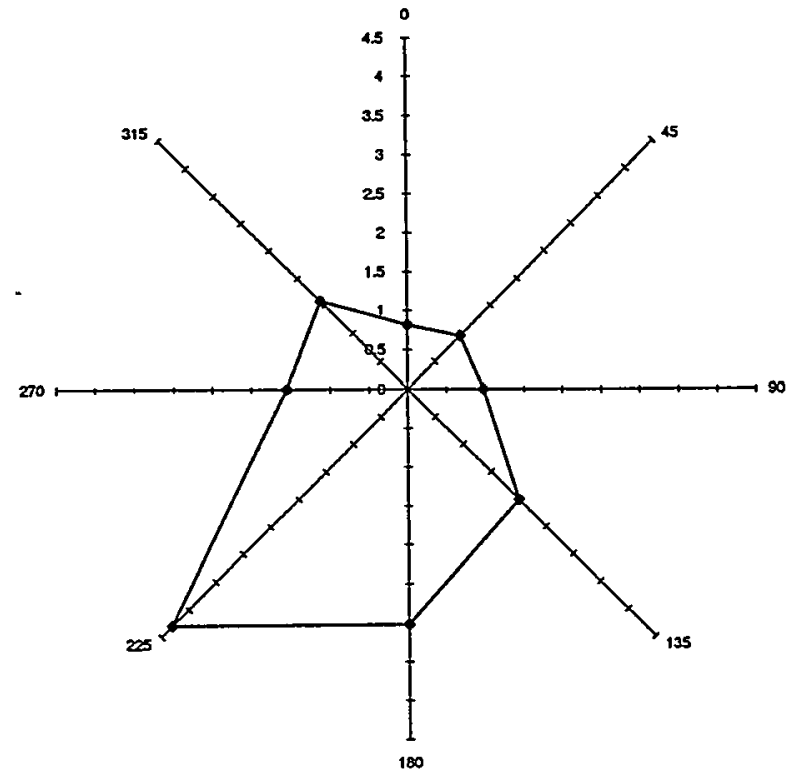

Figure $10 \mathrm{~b}$. Average wind speed $(\mathrm{m} / \mathrm{s})$ as a function of azimuth wind originated during the third week of experiment one (June 7 to June 14,1996 ).

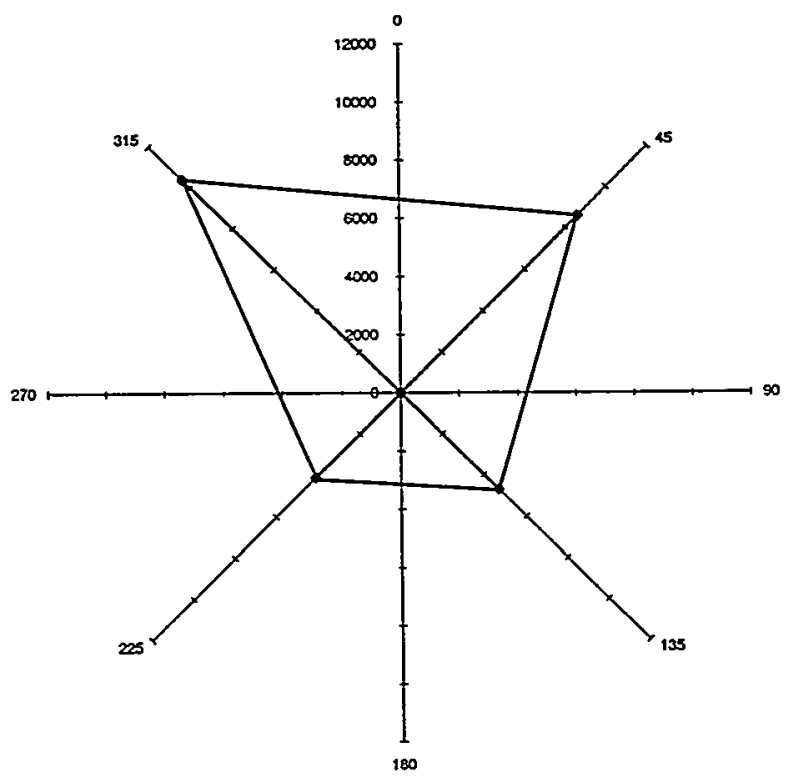

Figure 10d. Tritium concentration as a function of azimuth at $6.1 \mathrm{~m}$ from the experimental tank during the third week of experiment one (June 7 to June 14, 1996). 


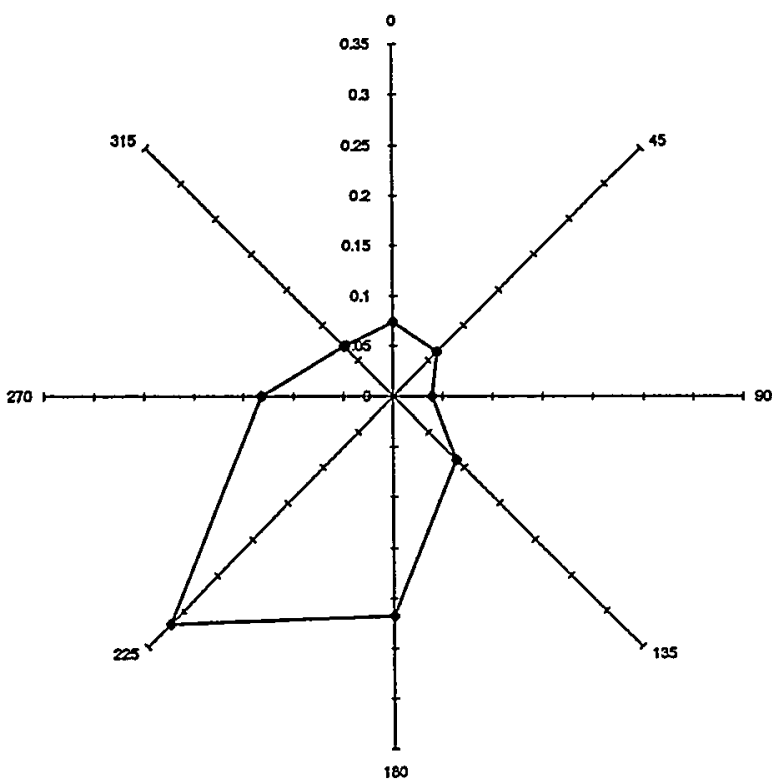

Figure 11a. Percent of time wind originated from a given azimuth during the final 10 days of experiment one (June 14 to June 24,1996 ).

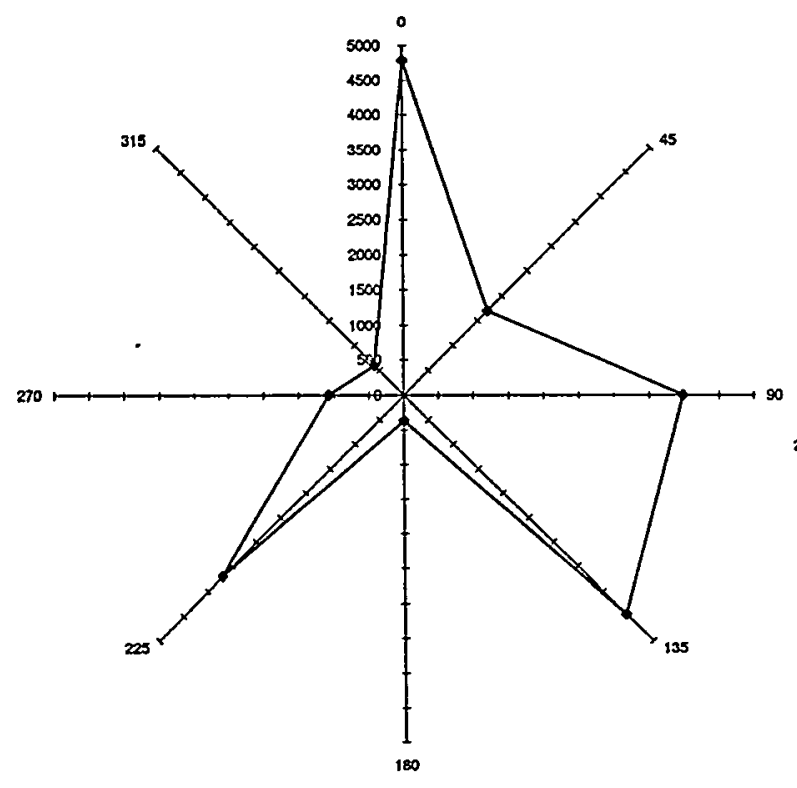

Figure 11c. Tritium concentration as a function of azimuth at $30.5 \mathrm{~m}$ from the experimental tank during the final 10 days of experiment one (June 14 to June 24, 1996).

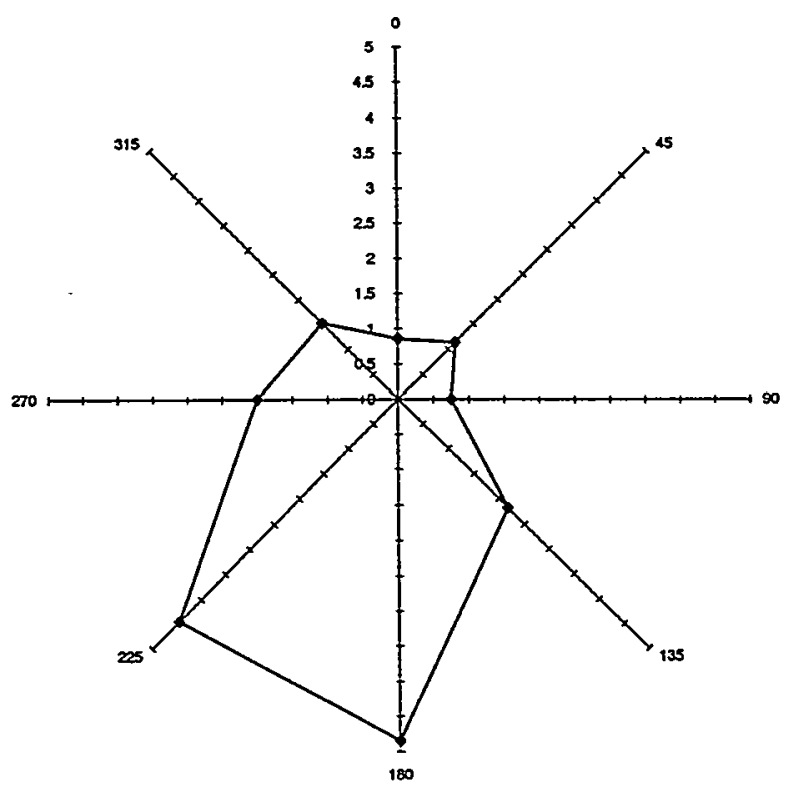

Figure $11 \mathrm{~b}$. Average wind speed $(\mathrm{m} / \mathrm{s})$ as a function of azimuth wind originated during the final 10 days of experiment one (June 14 to June 24,1996 ).

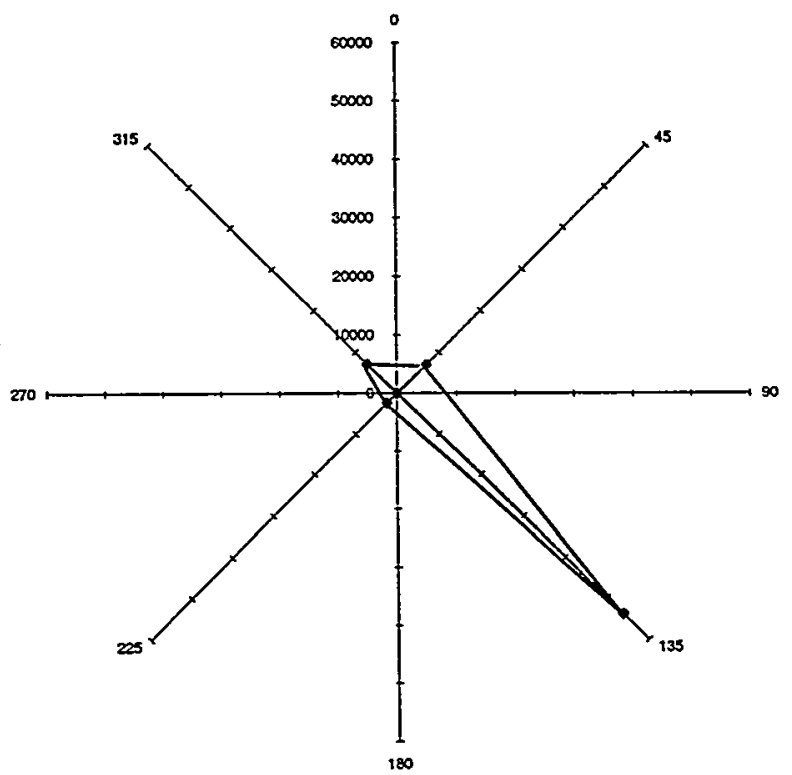

Figure 11d. Tritium concentration as a function of azimuth at $6.1 \mathrm{~m}$ from the experimental tank during the final 10 days of experiment one (June 14 to June 24, 1996). 


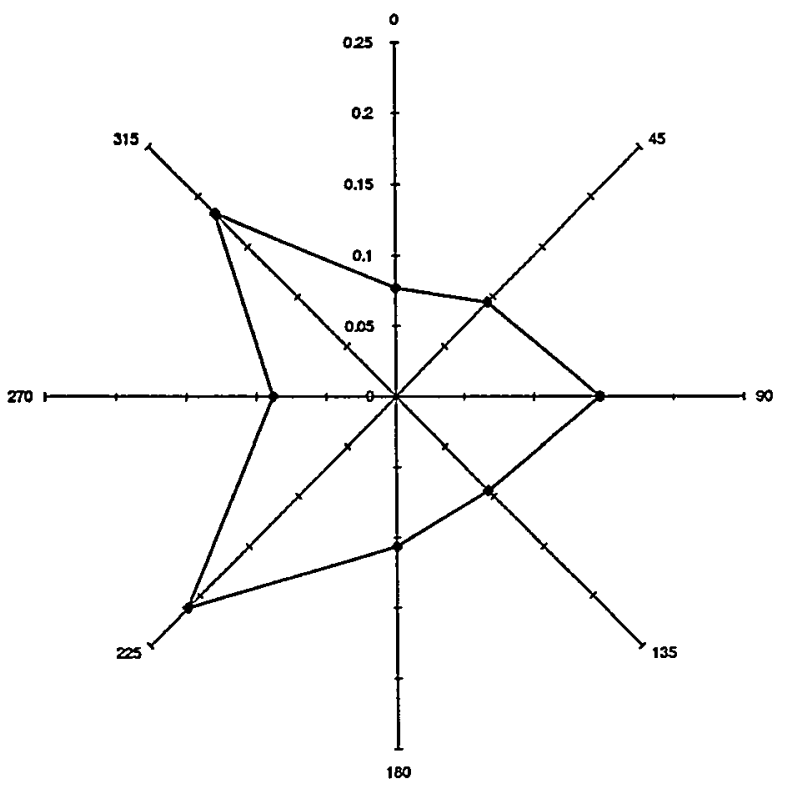

Figure 12a. Percent of time wind originated from a given azimuth during the first week of experiment two (June 28 to July 5,1996$)$.

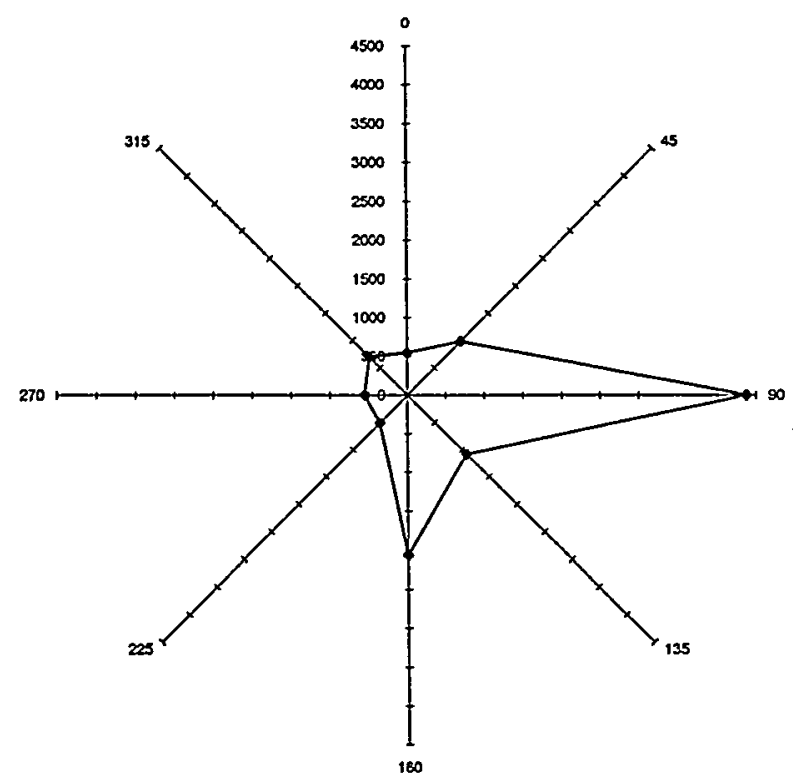

Figure 12c. Tritium concentration as a function of azimuth at $30.5 \mathrm{~m}$ from the experimental tank during the first week of experiment two (June 28 to July 5,1996$)$.

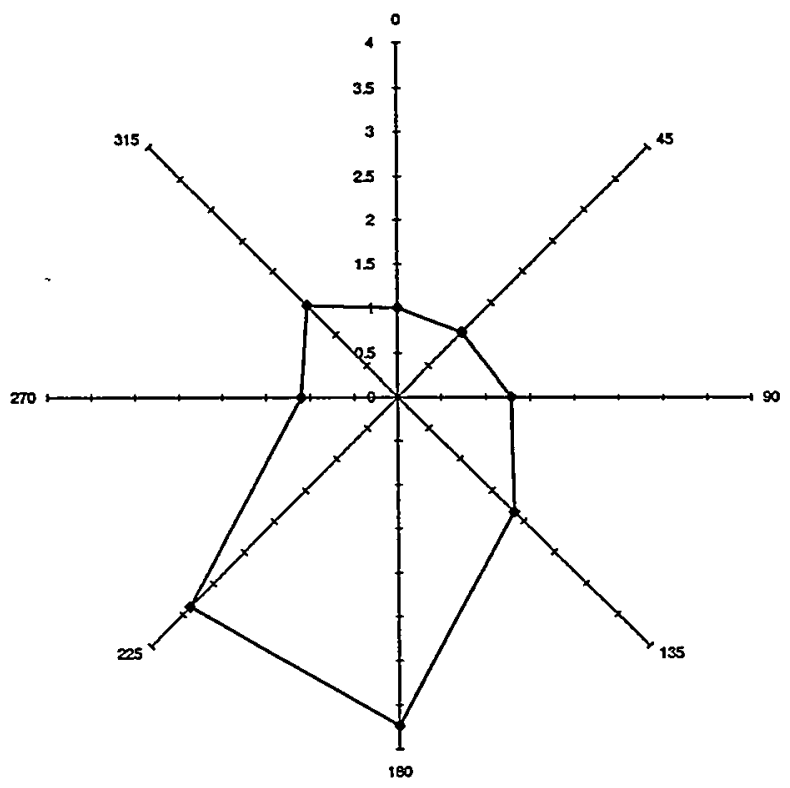

Figure $12 \mathrm{~b}$. Average wind speed $(\mathrm{m} / \mathrm{s})$ as a function of azimuth wind originated during the first week of experiment two (June 28 to July 5,1996 ).

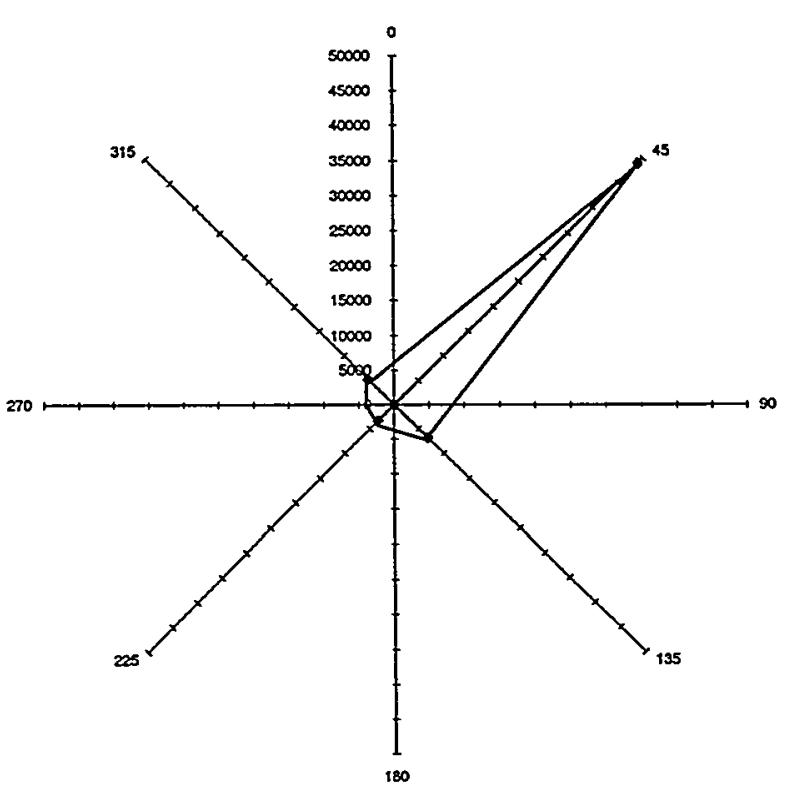

Figure 12d. Tritium concentration as a function of azimuth at $6.1 \mathrm{~m}$ from the experimental tank during the first week of experiment two (June 28 to July 5,1996 ). 


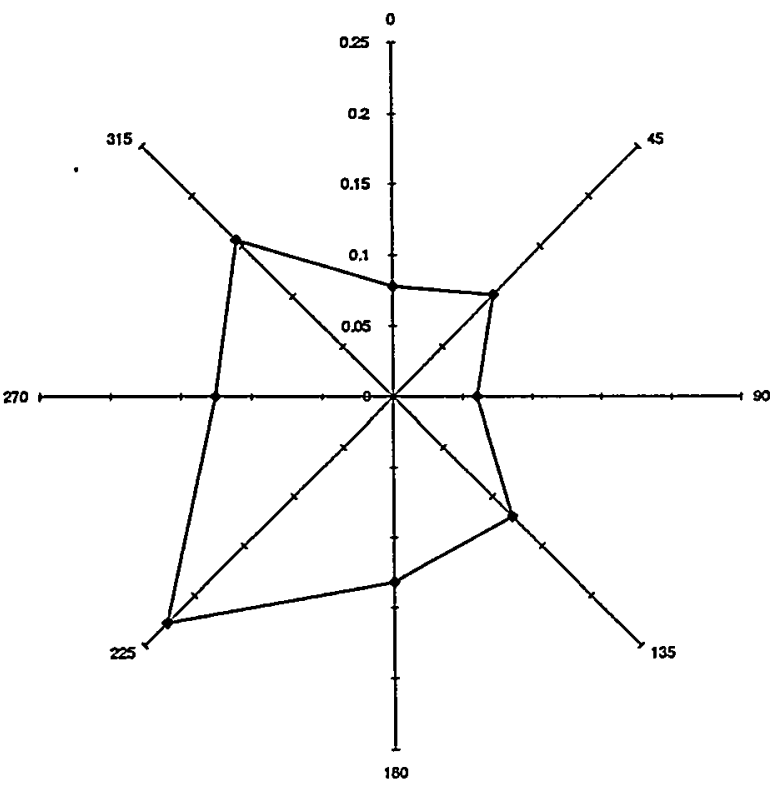

Figure 13a. Percent of time wind originated from a given azimuth during the second week of experiment two (July 5 to July 12,1996 ).

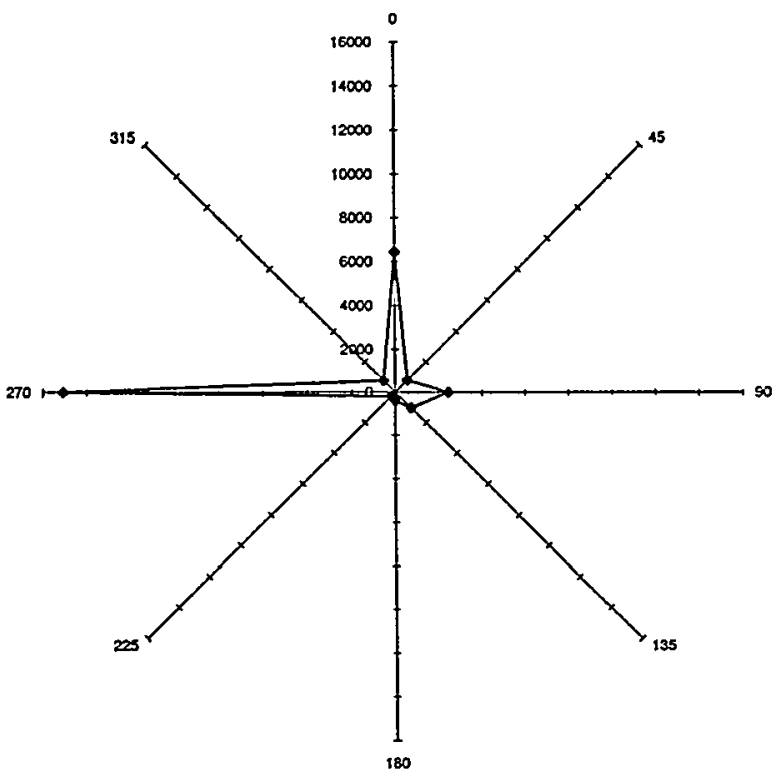

Figure $13 \mathrm{c}$. Tritium concentration as a function of azimuth at $30.5 \mathrm{~m}$ from the experimental tank during the second week of experiment two (July 5 to July 12,1996 ).

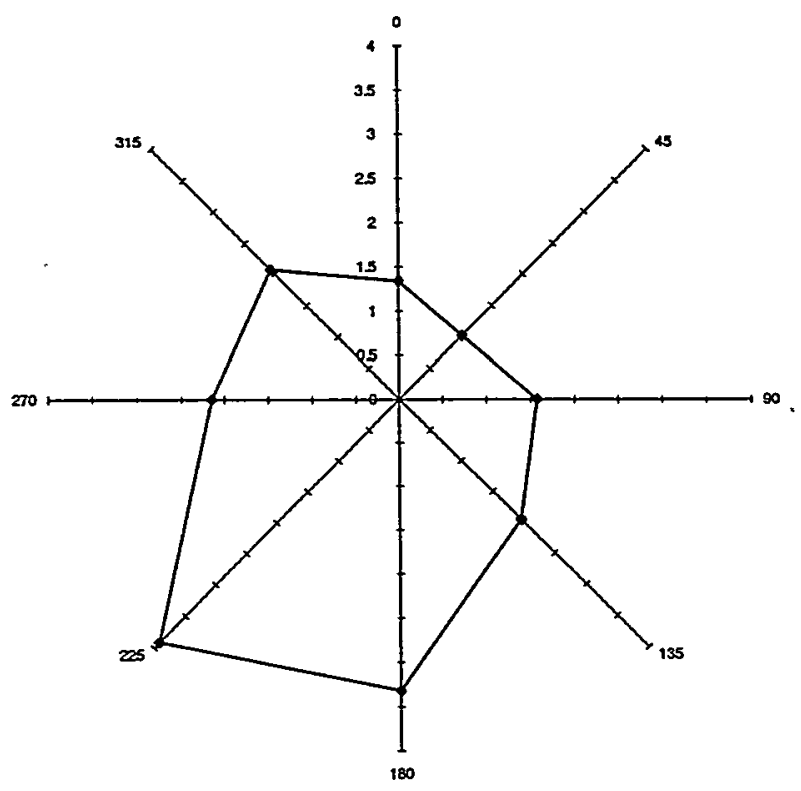

Figure $13 \mathrm{~b}$. Average wind speed $(\mathrm{m} / \mathrm{s})$ as a function of azimuth wind originated during the second week of experiment two (July 5 to July 12,1996 ).

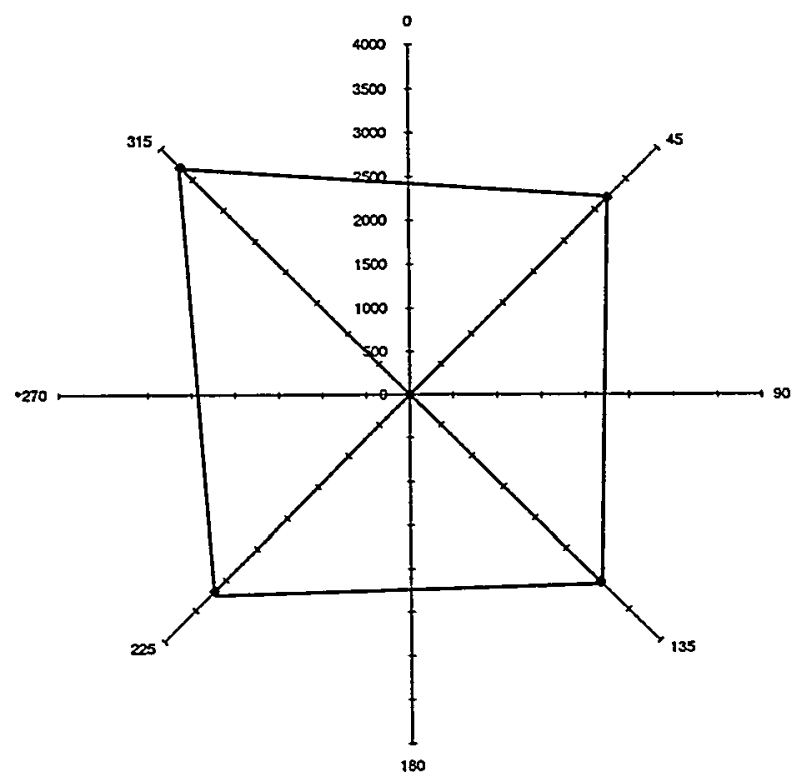

Figure 13d. Tritium concentration as a function of azimuth at $6.1 \mathrm{~m}$ from the experimental tank during the second week of experiment two (July 5 to July 12,1996 ). 


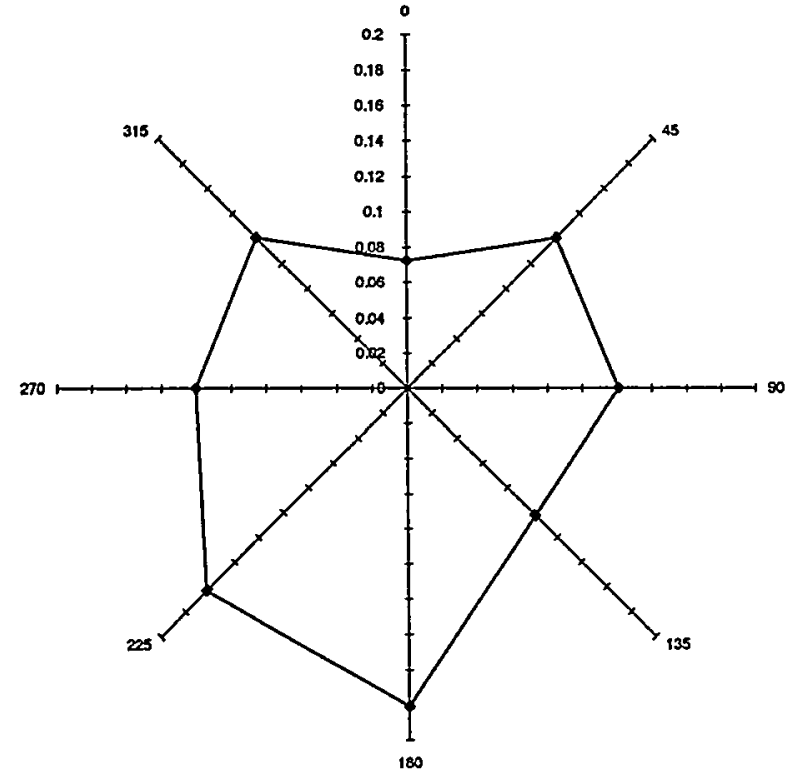

Figure 14a. Percent of time wind originated from a given azimuth during the third week of experiment two (July 12 to July 19, 1996).

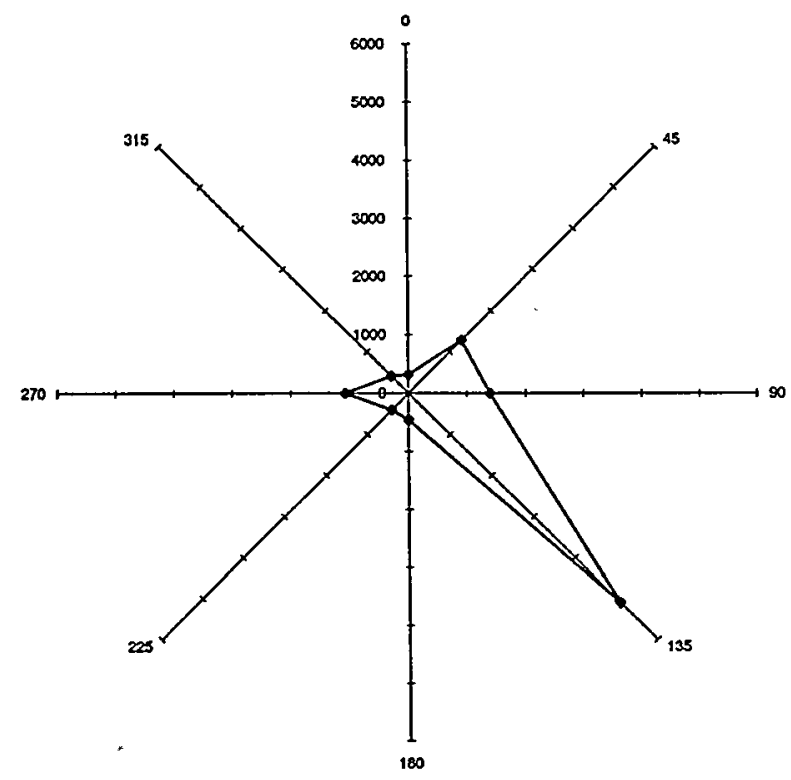

Figure 14c. Tritium concentration as a function of azimuth at $30.5 \mathrm{~m}$ from the experimental tank during the third week of experiment two (July 12 to July 19, 1996).

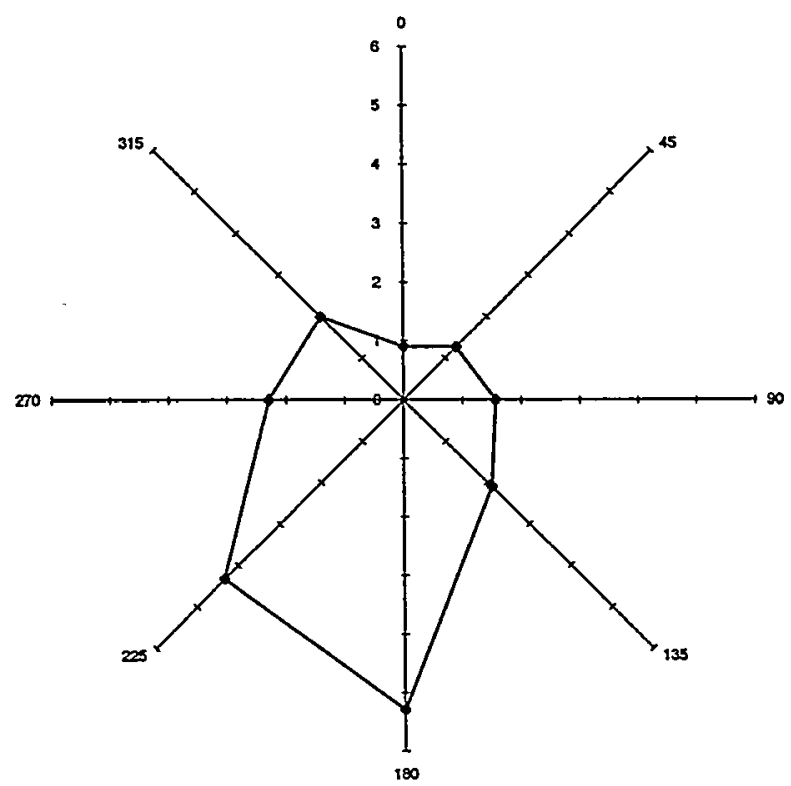

Figure $14 \mathrm{~b}$. Average wind speed $(\mathrm{m} / \mathrm{s})$ as a function of azimuth wind originated during the third week of experiment two (July 12 to July 19, 1996).

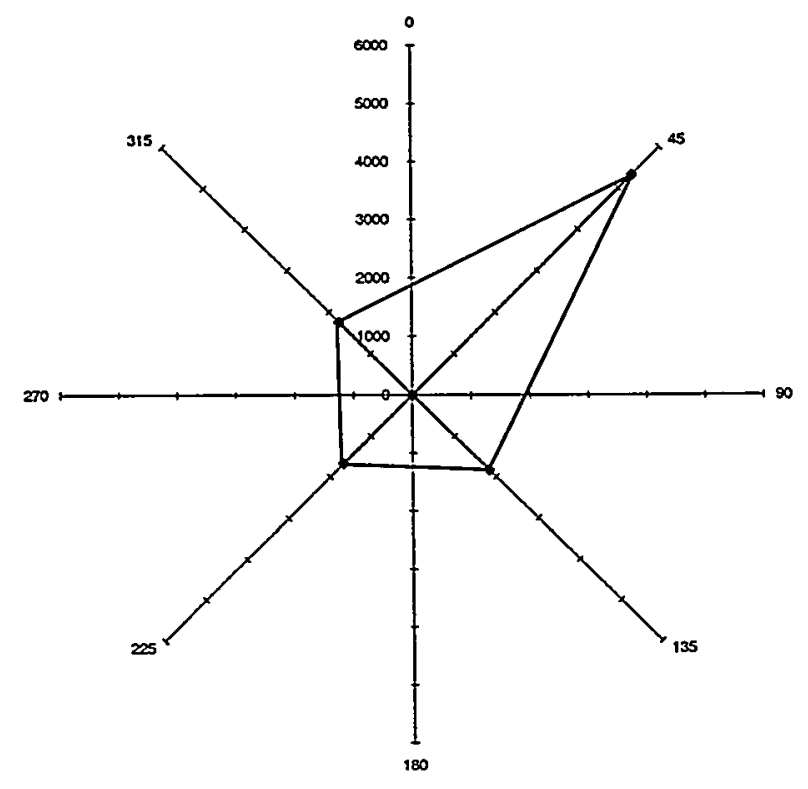

Figure 14d. Tritium concentration as a function of azimuth at $6.1 \mathrm{~m}$ from the experimental tank during the third week of experiment two (July 12 to July 19, 1996). 


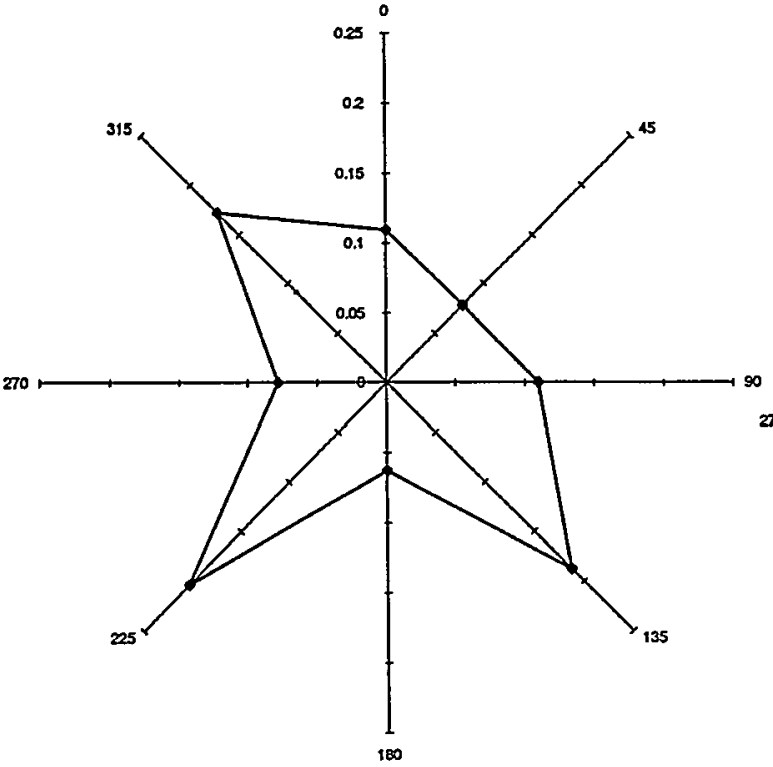

Figure 15a. Percent of time wind originated from a given azimuth during the final three days of experiment two (July 19 to July 22,1996 ).

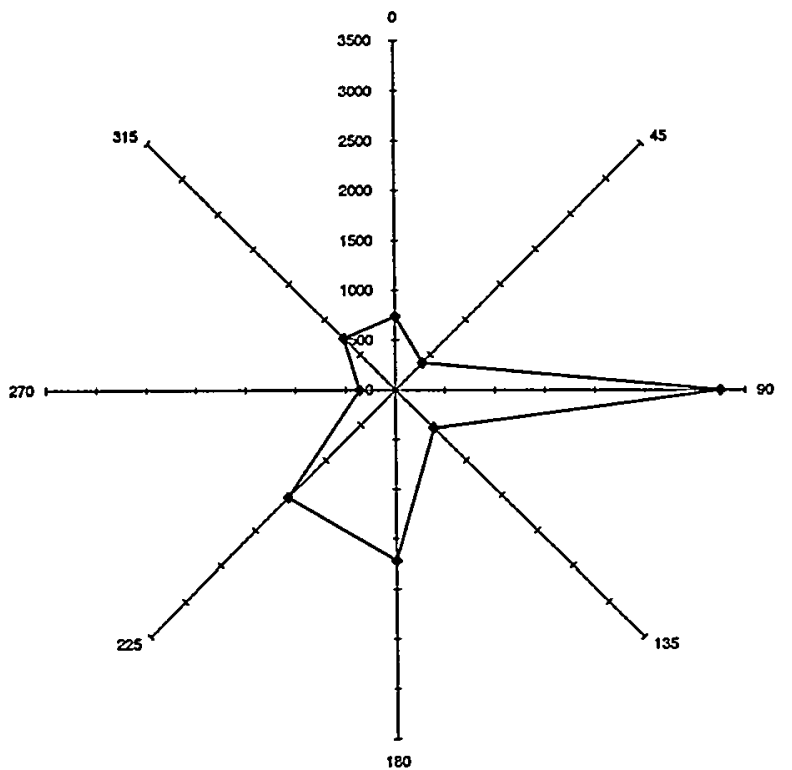

Figure 15c. Tritium concentration as a function of azimuth at $30.5 \mathrm{~m}$ from the experimental tank during the final three days of experiment two (July 19 to July 22, 1996).

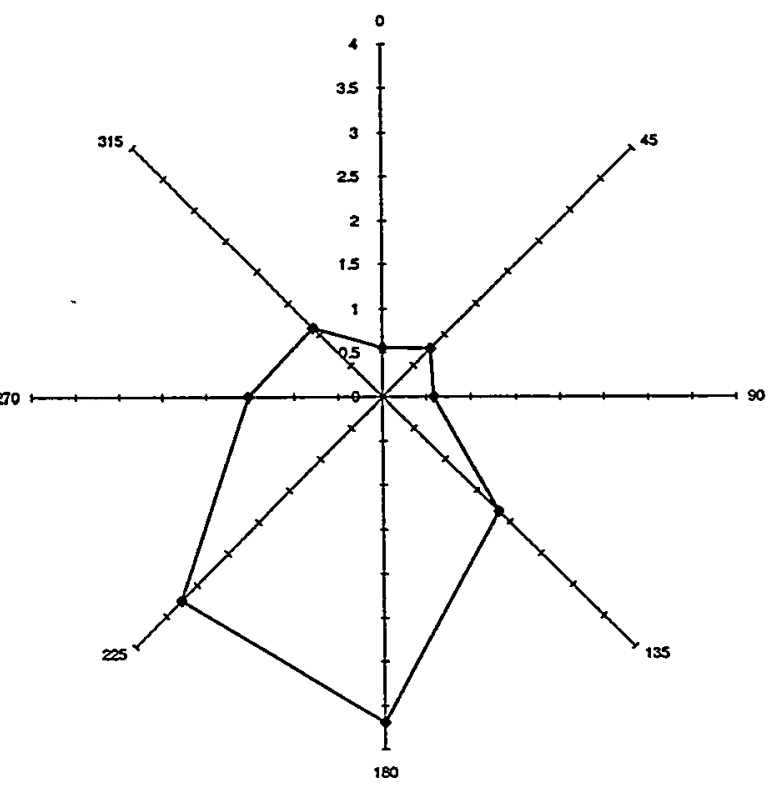

Figure $15 \mathrm{~b}$. Average wind speed $(\mathrm{m} / \mathrm{s})$ as a function of azimuth wind originated during the final three days of experiment two (July 19 to July 22, 1996).

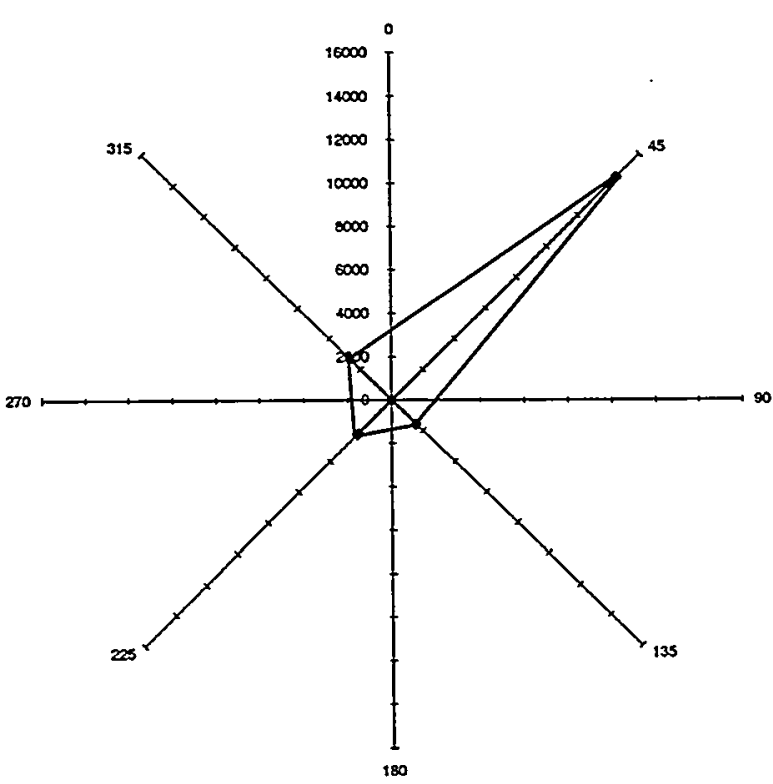

Figure 15d. Tritium concentration as a function of azimuth at $6.1 \mathrm{~m}$ from the experimental tank during the final three days of experiment two (July 19 to July 22,1996$)$. 


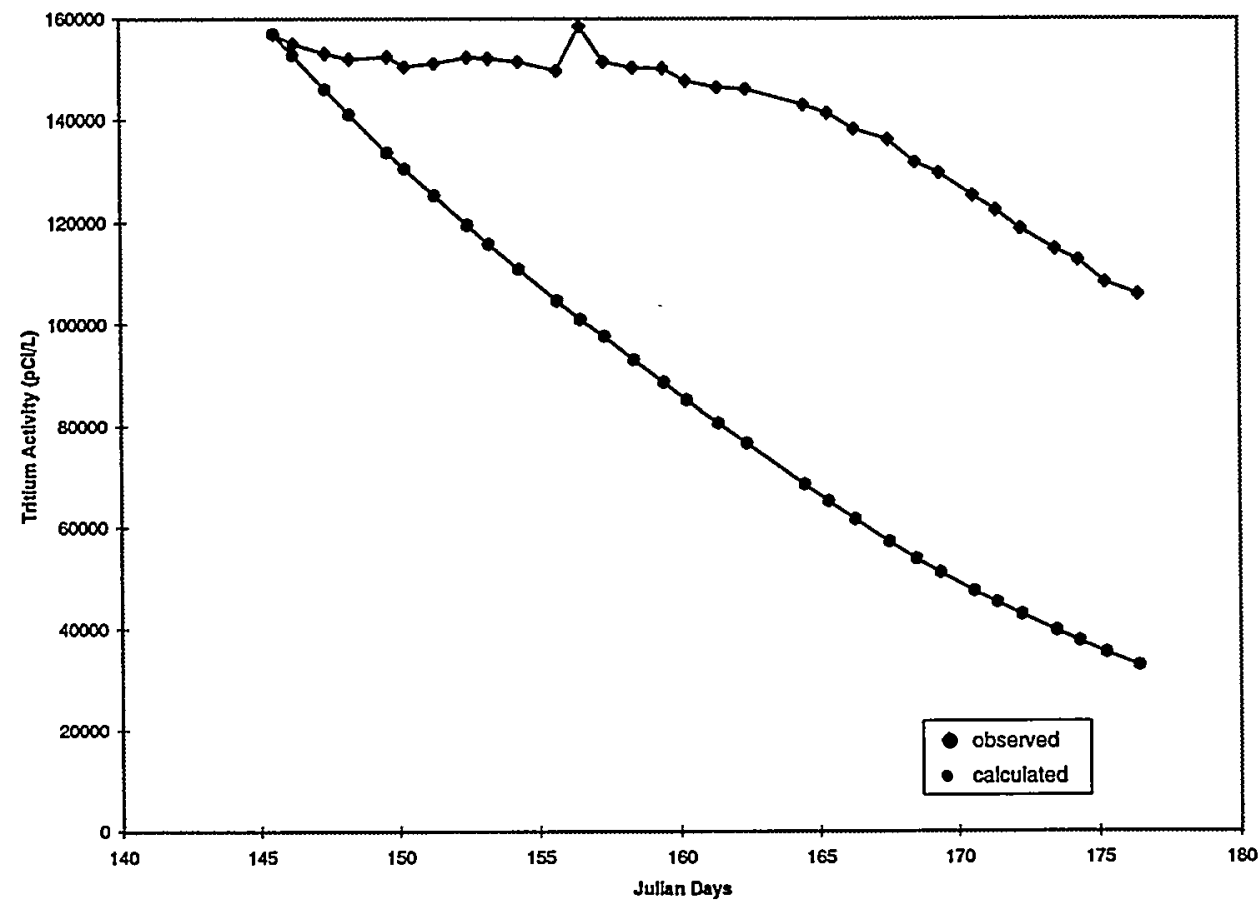

Figure 16. The change in tritium concentration as measured and modeled (Slattery and Ingraham, 1994) during the course of the first experiment.

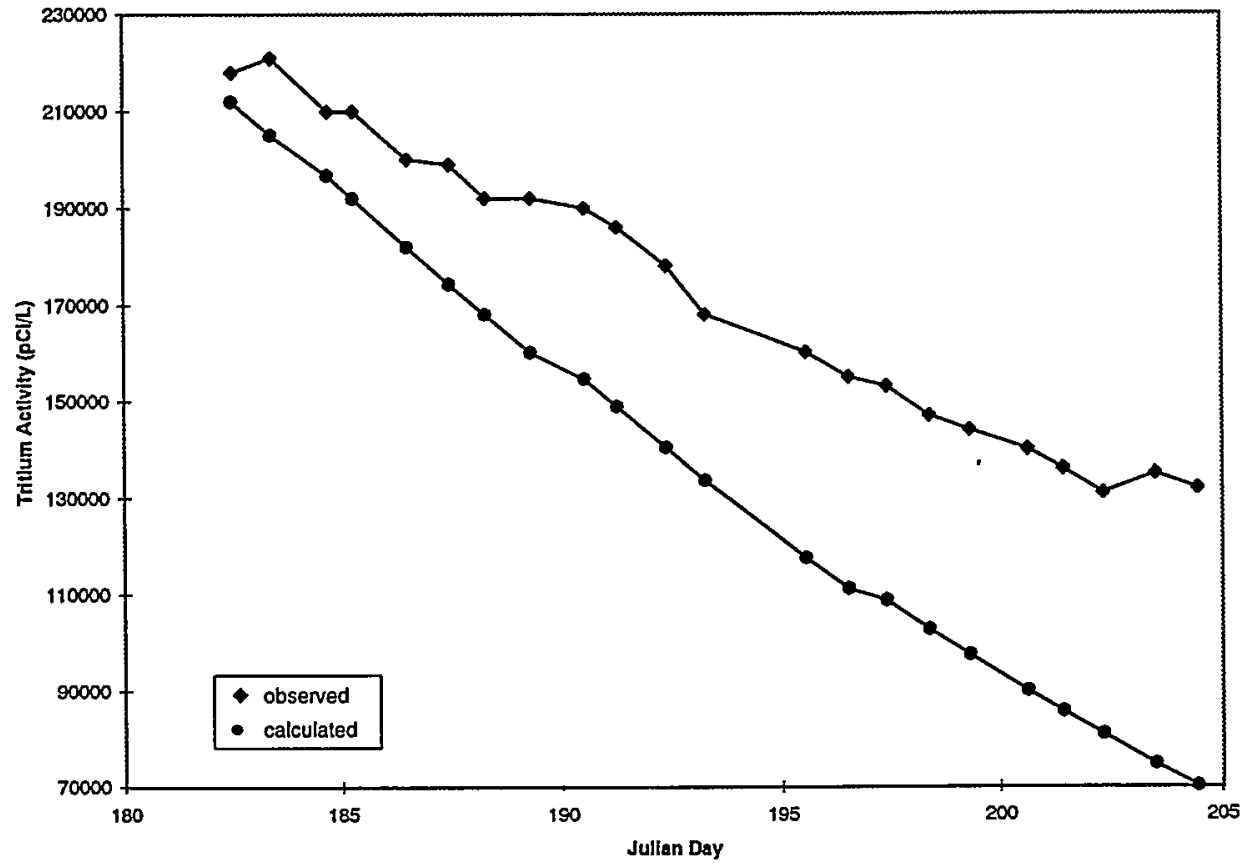

Figure 17. The change in tritium concentration as measured and modeled (Slattery and Ingraham, 1994) during the course of the second experiment. 
great deal of difficulty was encountered in attempting to humidify and monitor the humidity of the pressurized air stream. The humidifiers were partially to fully inoperative, due to defective equipment, during the first 22 days of experiment one. Field repairs were made and the humidifiers were made fully operational on June 15, 1996 (Julian day 167). A plot of the rate of evaporation for experiment one is given in Figure 18 and for experiment two in Figure 19. Examination of Figure 18 reveals rapid evaporation during the middle part of experiment one and lesser rates during the beginning and end. Slower rates of evaporation during the beginning of experiment one were due to higher levels of ambient humidity (Figure 20) and slower rates at the end were due to more effective operation of the humidifiers. Examination of Figure 19 reveals a consistent rate of evaporation over the duration of the experiment. All of experiment one and most of experiment two were conducted under evaporative conditions.

Equation (6) is an analytical solution for isotopic exchange under nonevaporative conditions. This condition was never reached during the course of the two experiments. A more complex derivation of Equation (6) will be required before it can be used to solve the observed changes in isotopic compositions under evaporative conditions.

An equation developed to describe the isotopic evolution of evaporative bodies (Craig and Gordon, 1965) has been shown, in previous sections, to be adequate for modeling the depletion of one isotope while simultaneously enriching another, depending upon the initial del difference of the isotopes for the atmosphere and the evaporating water. This model, described in Equations (7), (8), and (9), was discretized to model varying rates of humidity and measured rates of evaporation. Parameters utilized in the model are given in Table 4.

TABLE 4. VALUES UTILIZED TO SOLVE CRAIG AND GORDON (1965) FOR EXPERIMENTS ONE AND TWO.

\begin{tabular}{|c|c|c|c|c|c|c|}
\hline \multirow[b]{2}{*}{ Parameter } & \multicolumn{3}{|c|}{ Experiment 1} & \multicolumn{3}{|c|}{ Experiment 2} \\
\hline & Tritium & Deuterium & Oxygen-18 & Tritium & Deuterium & Oxygen-18 \\
\hline Humidity & \multicolumn{3}{|c|}{$9 \%-98 \%$} & \multicolumn{3}{|c|}{$7 \%$ to $72 \%$} \\
\hline Temperature & \multicolumn{3}{|c|}{$16.3-28.1^{\circ} \mathrm{C}$} & \multicolumn{3}{|c|}{$26.9-37.8^{\circ} \mathrm{C}$} \\
\hline $\begin{array}{l}\text { Fractionation } \\
\text { Factor** }\end{array}$ & $\begin{array}{l}1.105 \text { to } \\
1.116\end{array}$ & $\begin{array}{l}1.075 \text { to } \\
1.089\end{array}$ & $\begin{array}{l}1.0089 \text { to } \\
1.01\end{array}$ & $\begin{array}{l}1.081 \text { to } \\
1.10\end{array}$ & $\begin{array}{l}1.0661 \text { to } \\
1.0767\end{array}$ & $\begin{array}{l}1.0080 \text { to } \\
1.0091\end{array}$ \\
\hline $\begin{array}{l}\text { Isotopic Composition } \\
\text { of Air (del value)** }\end{array}$ & -0.99863 & -0.0118 & -0.104 & -0.99863 & -0.1012 & -0.0113 \\
\hline $\begin{array}{l}\text { Initial Isotopic } \\
\text { Composition of Water } \\
\text { (del value) }\end{array}$ & -0.01938 & -0.0121 & -0.098 & 0.36875 & -0.094 & -0.0113 \\
\hline $\begin{array}{l}\text { Fraction of Water } \\
\text { Remaining }\end{array}$ & $\begin{array}{l}\text { Given in } \\
\text { Figure } 18\end{array}$ & $\begin{array}{l}\text { Given in } \\
\text { Figure } 18\end{array}$ & $\begin{array}{l}\text { Given in } \\
\text { Figure } 18\end{array}$ & $\begin{array}{l}\text { Given in } \\
\text { Figure } 19\end{array}$ & $\begin{array}{l}\text { Given in } \\
\text { Figure } 19\end{array}$ & $\begin{array}{l}\text { Given in } \\
\text { Figure } 19\end{array}$ \\
\hline
\end{tabular}




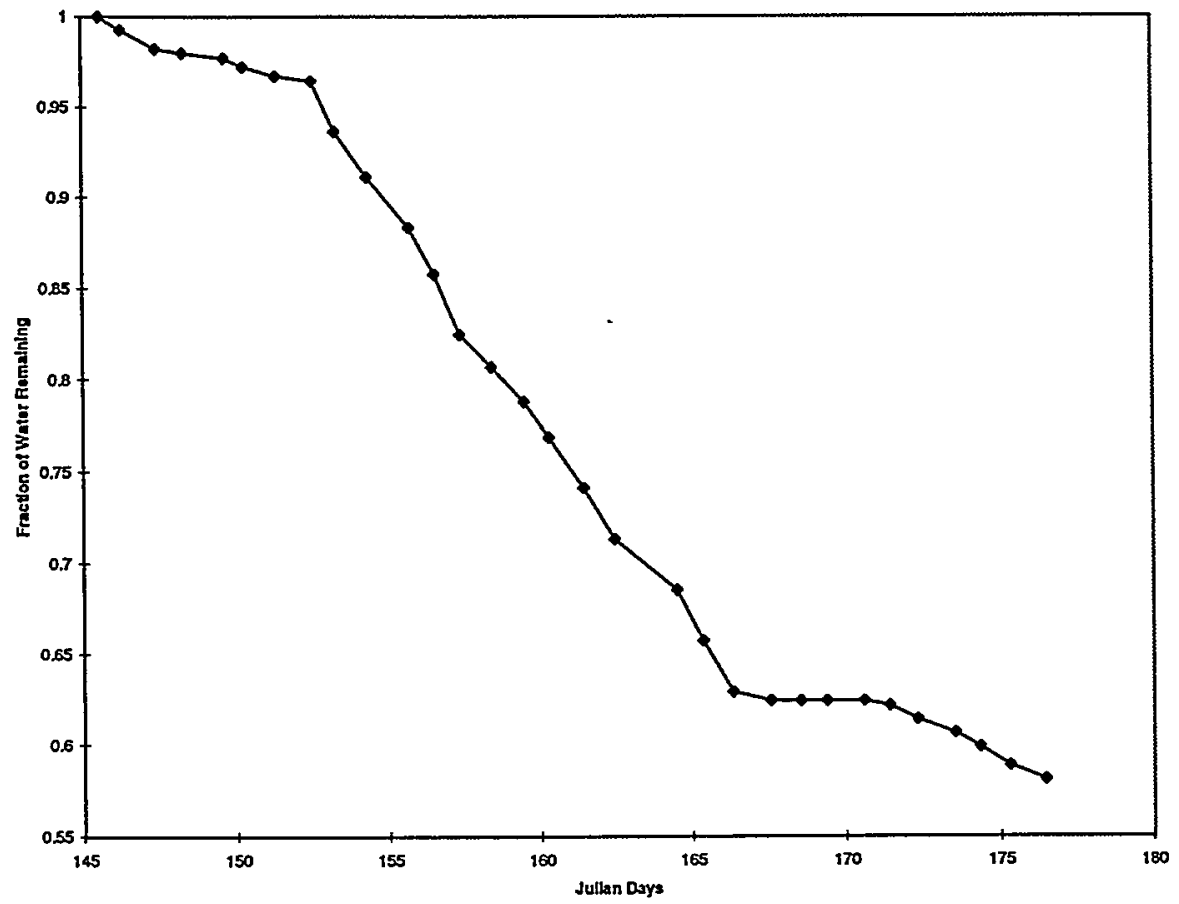

Figure 18. Fraction of water remaining within the experimental tank during the course of experiment one.

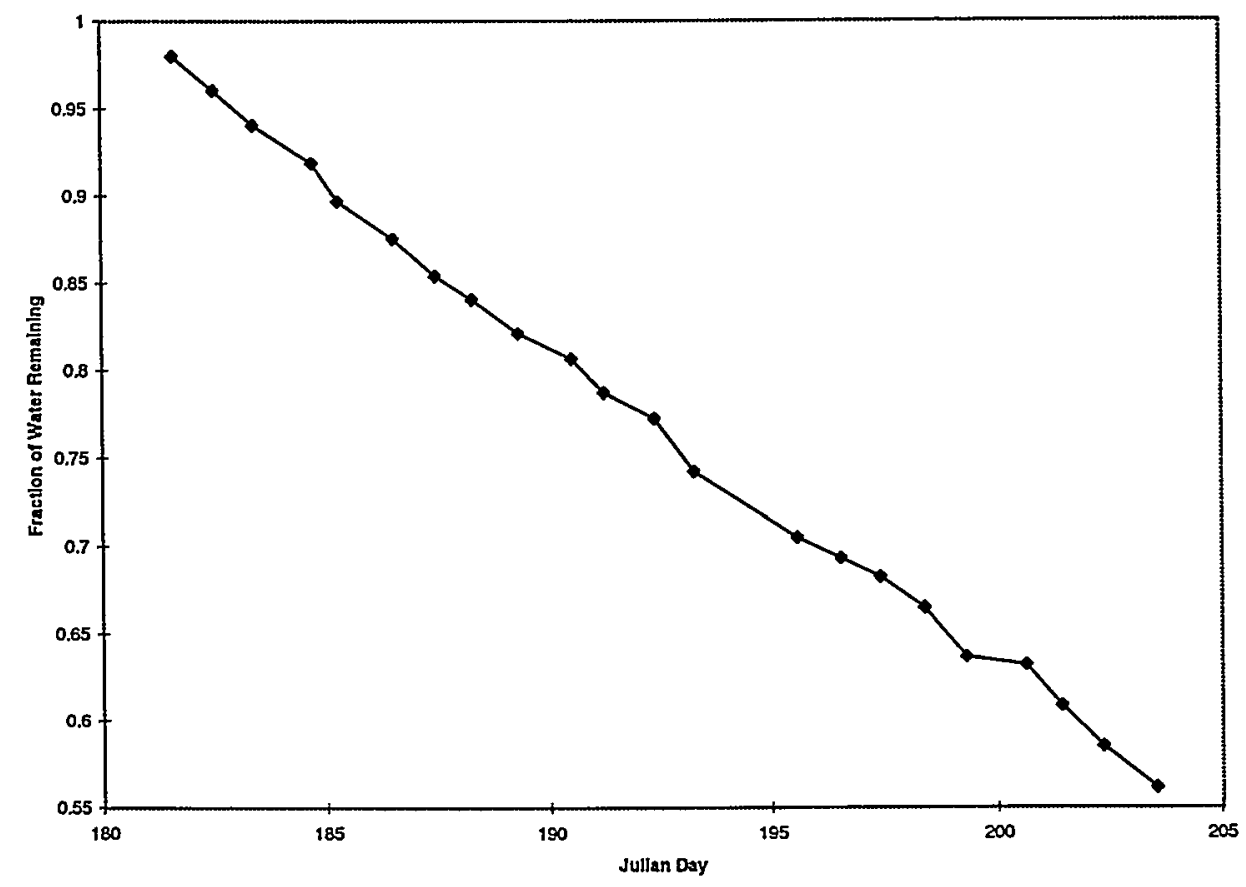

Figure 19. Fraction of water remaining within the experimental tank during the course of experiment two. 


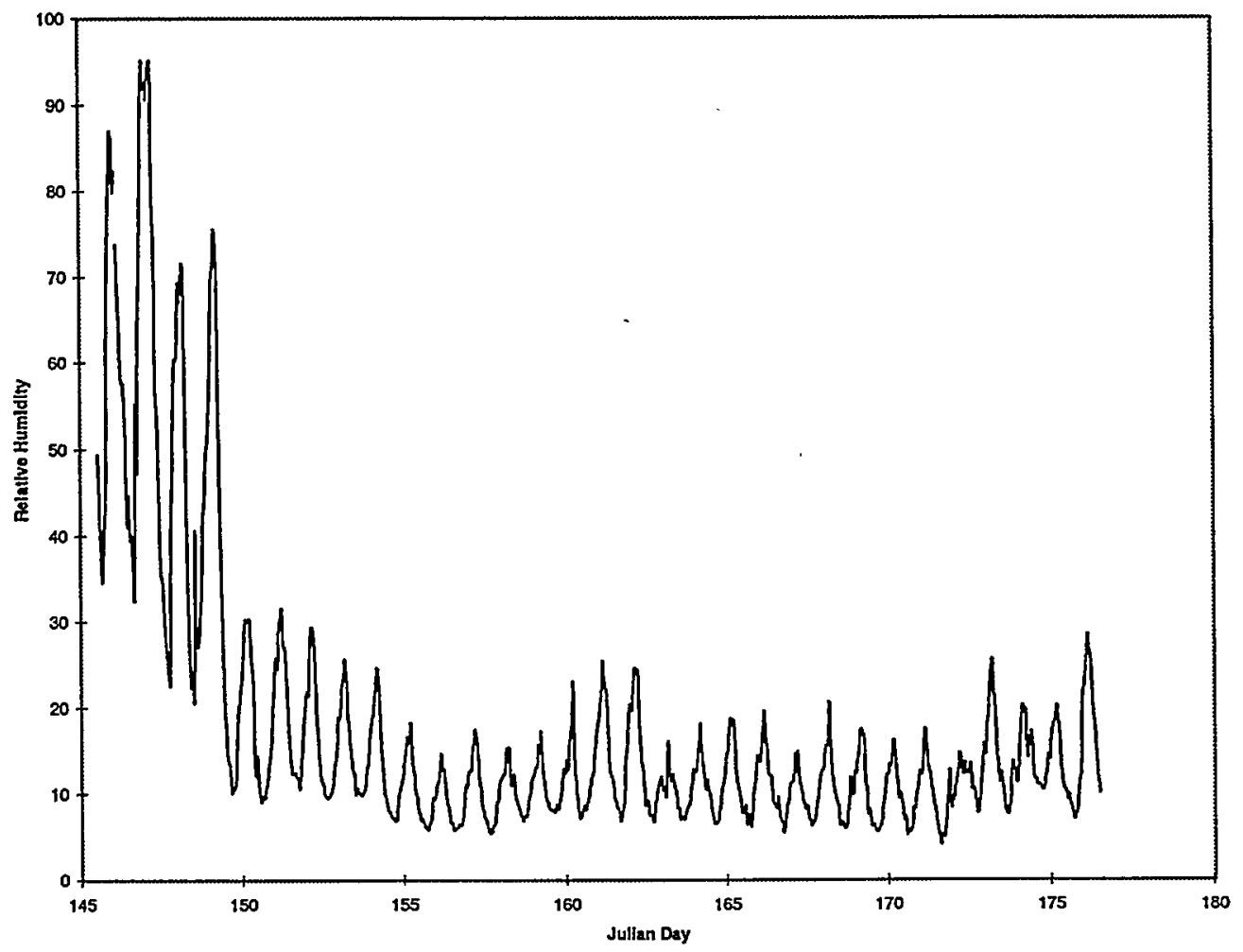

Figure 20. Ambient relative humidity encountered during the course of experiment one.

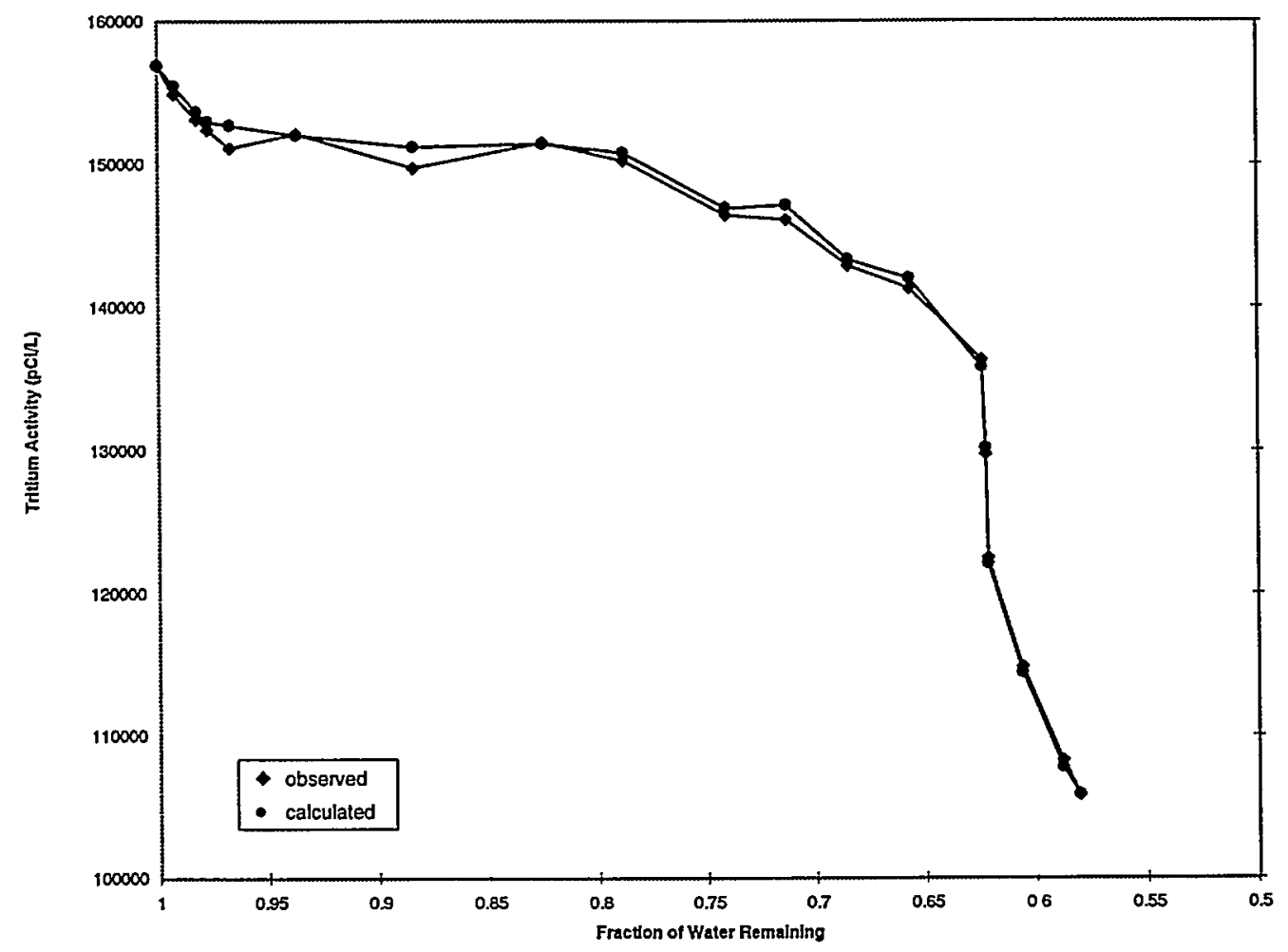

Figure 21. The change in tritium concentration as measured and modeled (utilizing Craig and Gordon, 1965) during the course of experiment one. The two lines coincide for virtually the entire graph. 
The results of the model, in terms of tritium, deuterium, and oxygen-18, for experiment one are given in Figures 21, 22, and 23. The results of the model for experiment two are given in Figures 24,25 , and 26. Examination of Figures 21 and 24 reveals an excellent fit of calculated to measured values for tritium as it depletes during the course of the experiment. The calculated humidity was optimized to produce this fit. The same humidity values were then utilized to calculate the enrichment of deuterium and oxygen-18 then compared to measured values (Figures 22, 23, 25, and 29). A comparison of the calculated rate of enrichment for deuterium to the measured values reveals that the model produces a reasonably good fit, indicating the calculated humidity was a reasonable estimate of experimental conditions. Direct measures of the humidity of the air stream were not obtained prior to contact with the tritiated water. Examination of the calculated versus measured enrichment of oxygen-18 reveals a poor fit, with measured values becoming enriched at a much slower rate than predicted. The oxygen-18 plots, if taken by themselves, would indicate unreasonable estimates of relative humidity were being used. However, this line of reasoning is unsupported by the deuterium data. A slower than predicted rate of enrichment for oxygen- 18 may be indicative of a sink, for the oxygen-18 isotopes, that is not included in the Craig and Gordon model.

The oxygen-18 isotope is a much less conservative tracer than the deuterium isotope. Oxygen within the water molecule is utilized in a number of low temperature aqueous reactions, such as the precipitation of calcium carbonate, the formation of iron oxide, and the growth of bacteria and algae. These reactions preferentially utilize the heavier oxygen-18 isotope, creating a sink for this isotope. A number of contaminants were observed to increase in the water during both experiments. These include iron oxide and algae. The presence of these contaminants offers a possible explanation of why oxygen-18 does not enrich at the predicted rate.

Overall, the Craig and Gordon model was successful in describing the rate of tritium depletion during the course of the two experiments. This model may be utilized, along with estimates of evaporation, to estimate and/or evaluate the performance of the technique of air sparging for the removal of tritium from tritiated reservoirs. An assessment of the performance of the technique during the course of experiment one and two is given in Table 5 .

TABLE 5. PERFORMANCE OF AIR-SPARGING METHODOLOGY DURING EXPERIMENT ONE AND TWO.

\begin{tabular}{lcc}
\hline & Experiment One & Experiment Two \\
\hline Initial Volume & $36,019 \mathrm{~L}$ & $38,919 \mathrm{~L}$ \\
Initial Tritium Concentration & $156,900 \mathrm{pCi} / \mathrm{L}$ & $219,000 \mathrm{pCi} / \mathrm{L}$ \\
Initial Tritium Mass & $5.65 \times 10^{9} \mathrm{pCi} / \mathrm{L}$ & $8.52 \times 10^{9} \mathrm{pCi} / \mathrm{L}$ \\
Final Volume & $20,926 \mathrm{~L}$ & $21,841 \mathrm{~L}$ \\
Final Tritium Concentration & $105800 \mathrm{pCi} / \mathrm{L}$ & $132,000 \mathrm{pCi} / \mathrm{L}$ \\
Final Tritium Mass & $2.21 \times 10^{9} \mathrm{pCi} / \mathrm{L}$ & $2.88 \times 10^{9} \mathrm{pCi} / \mathrm{L}$ \\
Total Mass of Tritium Removed & $3.44 \times 10^{9} \mathrm{pCi} / \mathrm{L}$ & $5.64 \times 10^{9} \mathrm{pCi} / \mathrm{L}$ \\
Percent Tritium Removed & 60.8 & 66.2 \\
\hline
\end{tabular}




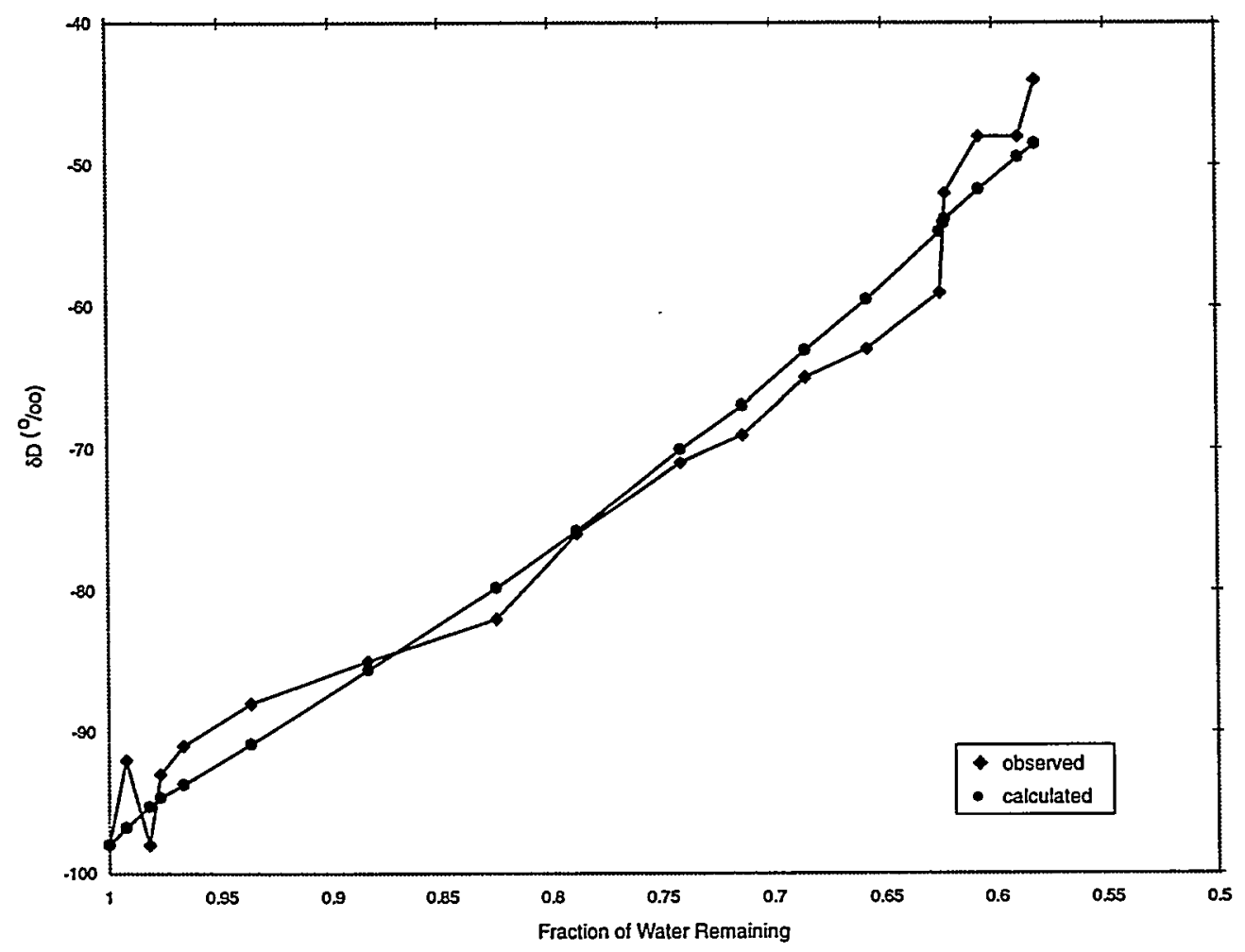

Figure 22. Observed versus modeled results (utilizing Craig and Gordon, 1965) for deuterium enrichment during the course of experiment one.

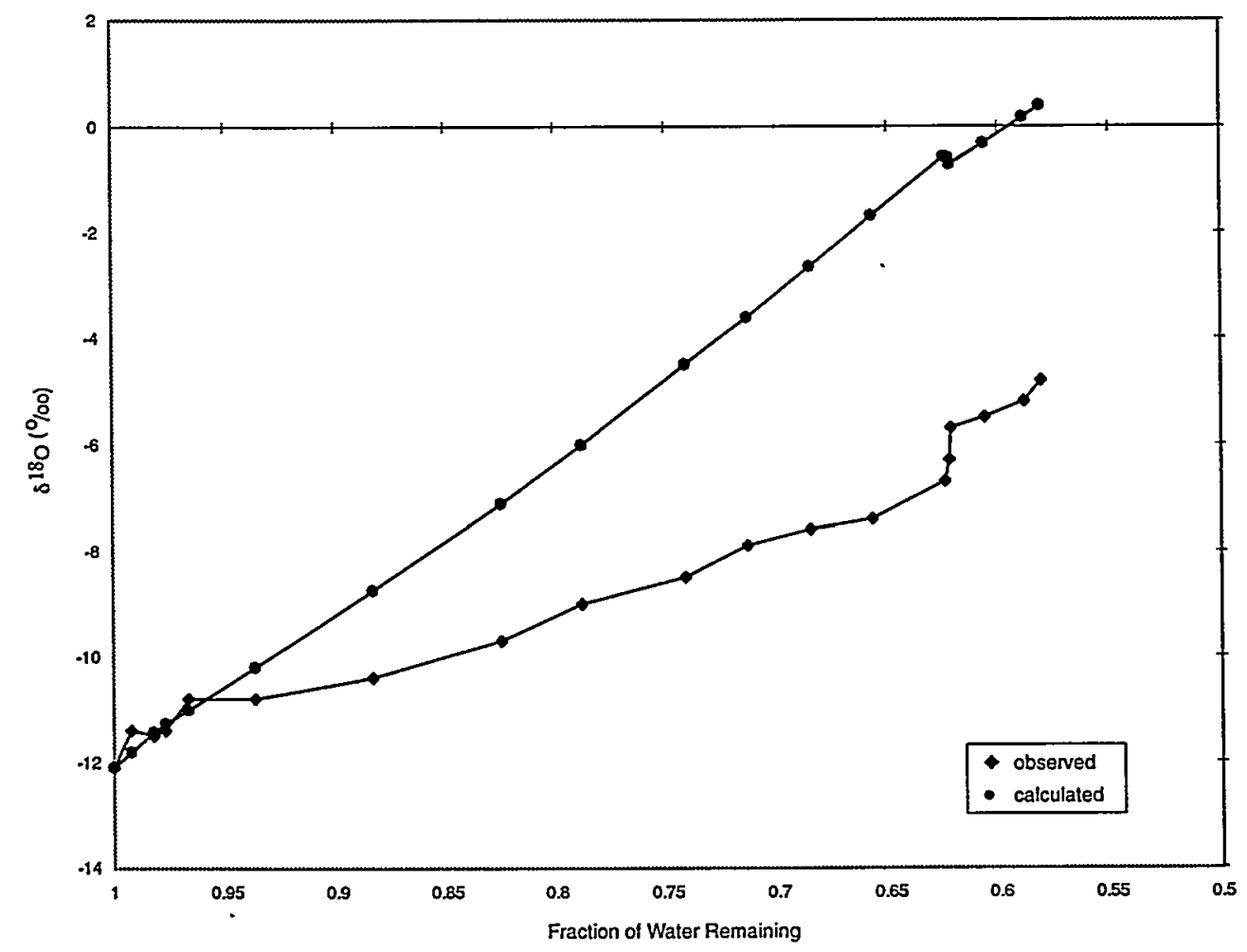

Figure 23. Observed versus modeled results (utilizing Craig and Gordon, 1965) for oxygen-18 enrichment during the course of experiment one. 


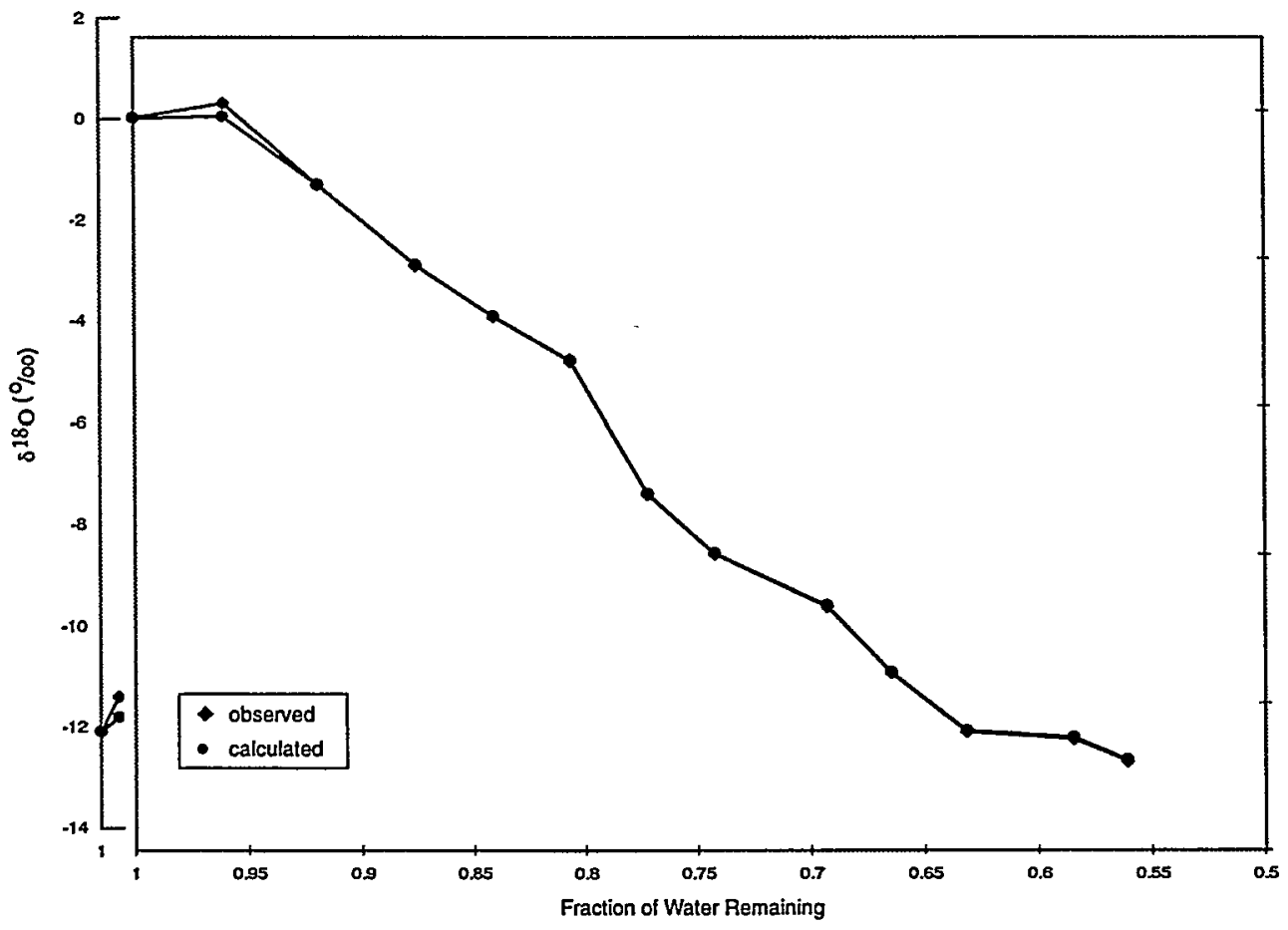

Figure 24. The change in tritium concentration as measured and modeled (utilizing Craig and Gordon, 1965) during the course of experiment two. The two lines coincide for virtually the entire graph.

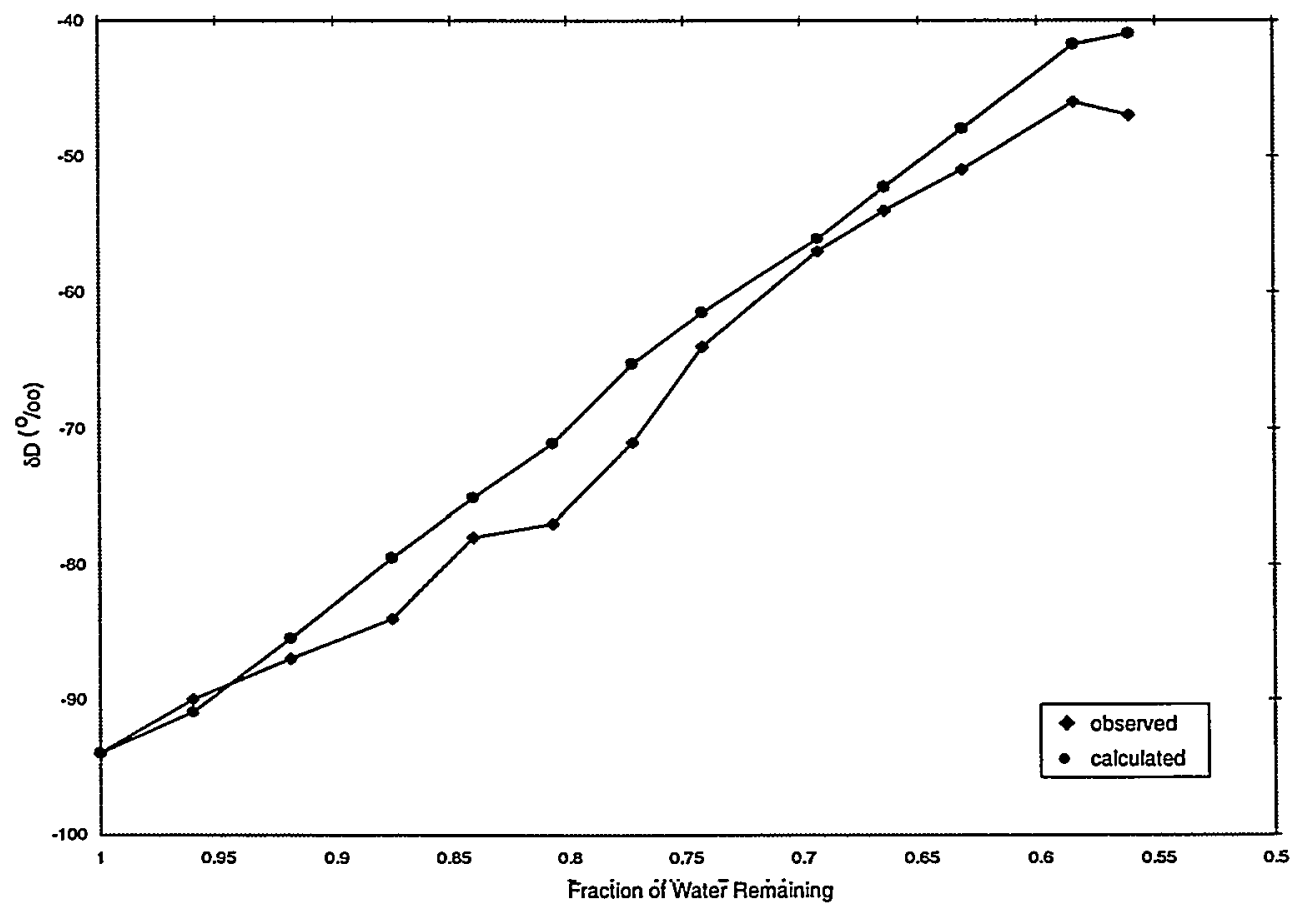

Figure 25. Observed versus modeled results (utilizing Craig and Gordon, 1965) for deuterium enrichment during the course of experiment two. 


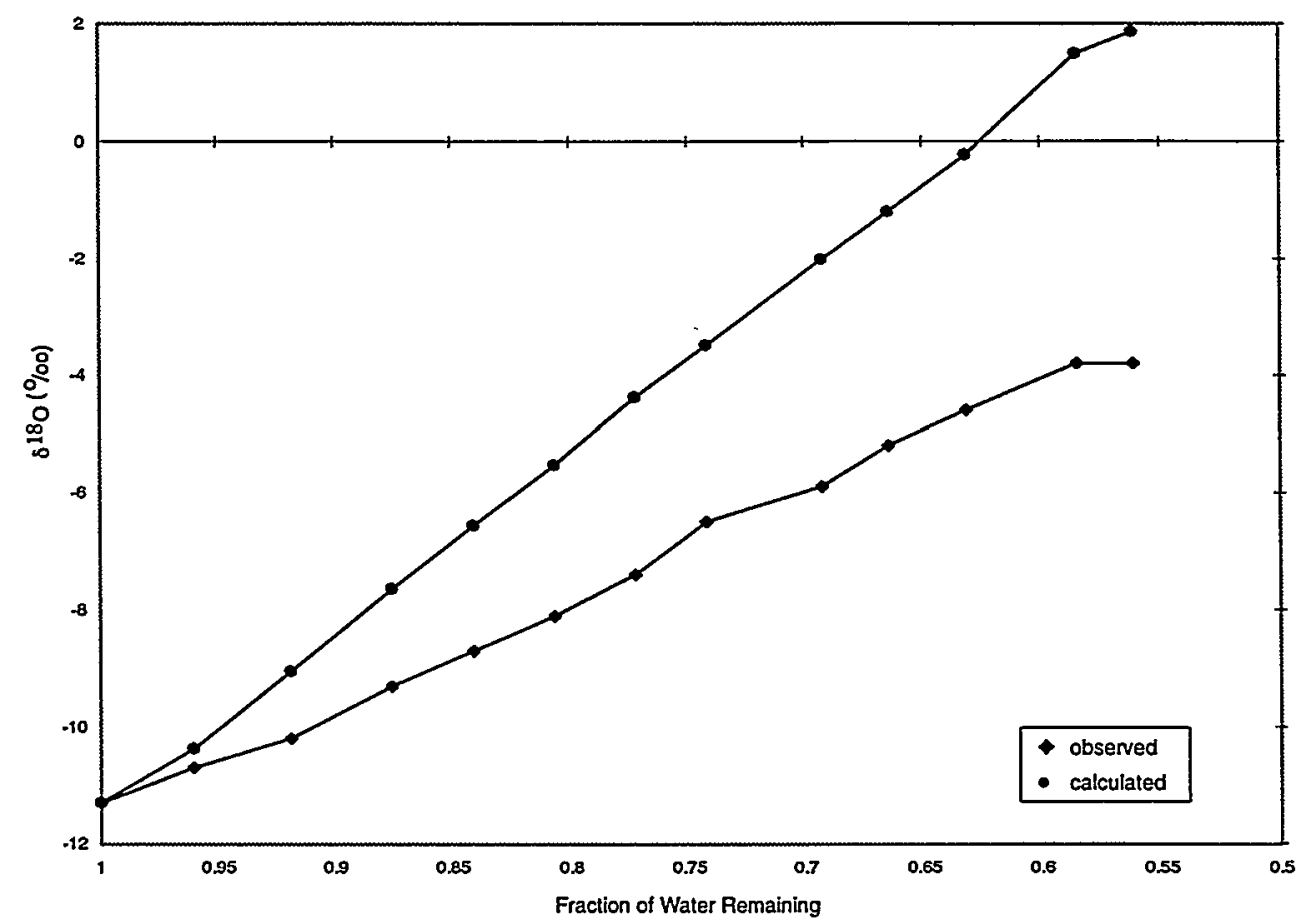

Figure 26. Observed versus modeled results (utilizing Craig and Gordon, 1965) for oxygen-18 enrichment during the course of experiment two.

Evaluation of Table 5 reveals that experiment two was much more effective at removing tritium during the course of its 22.83-day duration relative to experiment one, which was run for 30.89 days. There are several reasons for this. Experiment one had a lower initial concentration, a lower air flow rate, a lower temperature, and was covered by a tarp that inhibited evaporation. Experiment two's higher initial concentration, temperature, air flow rate, and higher rate of evaporation, due to the removal of the tarp, allowed for a greater mass of tritium to be removed per unit time.

Comparison of the results of this study to that of previous laboratory investigations reveals that the field study produced average and not optimal performance. Laboratory studies conducted by Wilson (1995) reported removal rates for experiments conducted in 28-L tanks with initial tritium activities of $400,000 \mathrm{pCi} / \mathrm{L}$ and an aeration rate of $14 \mathrm{~L} / \mathrm{min}$ (utilizing humidified air) of up to 96.7 percent over a period of 38 days. These experiments were conducted in tanks that were uncovered and placed in fume hoods to remove tritiated vapor from the laboratory. Identical experiments, in which the tanks were not aerated, were also conducted. The nonaerated tanks underwent approximately 25 percent reduction in tritium mass over a period of 10 days. This reduction is very likely due to the increase in airflow, created by the fume hood, passing over the surface of the experiment, thereby increasing the rates of evaporation. Identical experiments conducted by Wilson (1995) that were covered (removing the effects of the air flow induced by the fume hood) underwent approximately 60 percent reduction in 30 days, a rate exchange similar to those reported by Slattery and Ingraham (1993) and in this report. 
Wilson (1995) also reported removal rates for experiments conducted in 211-L columns with initial tritium activities of $400,000 \mathrm{pCi} / \mathrm{L}$, an aeration rate of $226 \mathrm{~L} / \mathrm{min}$ (utilizing low humidity air), of up to 87.6 percent for 30 days of operation. This rate exceeds those determined during the course of the experiments reported herein. Slattery and Ingraham (1973) reported a theoretical basis for increasing removal rates by decreasing bubble size (smaller bubbles equilibrate with the tritium activity of the surrounding water at a much faster rate than occurs with larger bubbles). Bubble sizes utilized in Wilson (1995) were $0.007 \mathrm{~cm}$ in diameter, while those produced during the course of the field experiments were 2 to $3 \mathrm{~cm}$ in diameter. In addition, flowpaths for the Wilson (1995) experiments were $2.90 \mathrm{~m}$ versus a maximum bubble path length of $1.25 \mathrm{~m}$ for the field experiments. Improvement in the performance of the field experiment could have been achieved by utilizing diffusers that produce smaller bubbles that travel longer distances through the tritiated fluid.

It has been shown in the previous discussion that the depletion rate of tritium in a reservoir is directly proportionate to the humidity of the injected air and to the rate of evaporation. However, the higher the humidity, the slower evaporation occurs. An assessment of the change in tritium mass with respect to time, as a function of relative humidity needs to be conducted.

Figure 27 is the percent depletion of tritium versus fraction of water remaining for an idealized model of experiment two as operated under various levels of relative humidity. The five lines in Figure 27 correspond to the change in tritium activity as a function of differing levels of relative humidity. Figure 27 demonstrates that tritium in the reservoir is depleted at a much greater rate, per unit quantity of water evaporated under conditions of higher relative humidity. At lower relative humidity, the water remaining in the reservoir is actually enriched. Figure 28 is a graph of the change in tritium mass within the tank under the same conditions as shown in Figure 27. However, the rate of change in tritium activity is now plotted against the duration in days it requires to evaporate the tank to the fraction of water remaining utilized as the $x$-ordinate in Figure 27. The rate of evaporation is a function of relative humidity; this rate was determined by utilizing a modified version of the Lake Mead evaporation equation (Harbeck et al., 1958) to estimate duration of time required to evaporate a given quantity of water, as a function of relative humidity. The modification consists of inclusion of a scaling factor that increases the rate of evaporation per unit time to account for the increased turbulence and evaporation surface due to the aeration process. Examination of Figure 28 reveals that evaporation under 0 percent humidity is the most rapid method for reducing the total tritium inventory, this method also increases the activity of the water that remains. Evaporation at higher levels of humidity requires several times longer to reduce the tank to a similar tritium inventory, however, there is no concurrent enrichment of any water that remains.

\section{Risk Assessment}

Air sparging removes tritium from the aqueous phase and releases it to the atmosphere. The potential receptors of this tritiated vapor include any animal, person, or body of water that is downwind of the experiment, to a distance where the plume has been reduced to background levels by mixing and diffusion. A substantial effort was made during the course of the experiments to evaluate the risk associated with running the experiment to potential human receptors. The activities of the air directly above the experiment are given in Table 6 . 


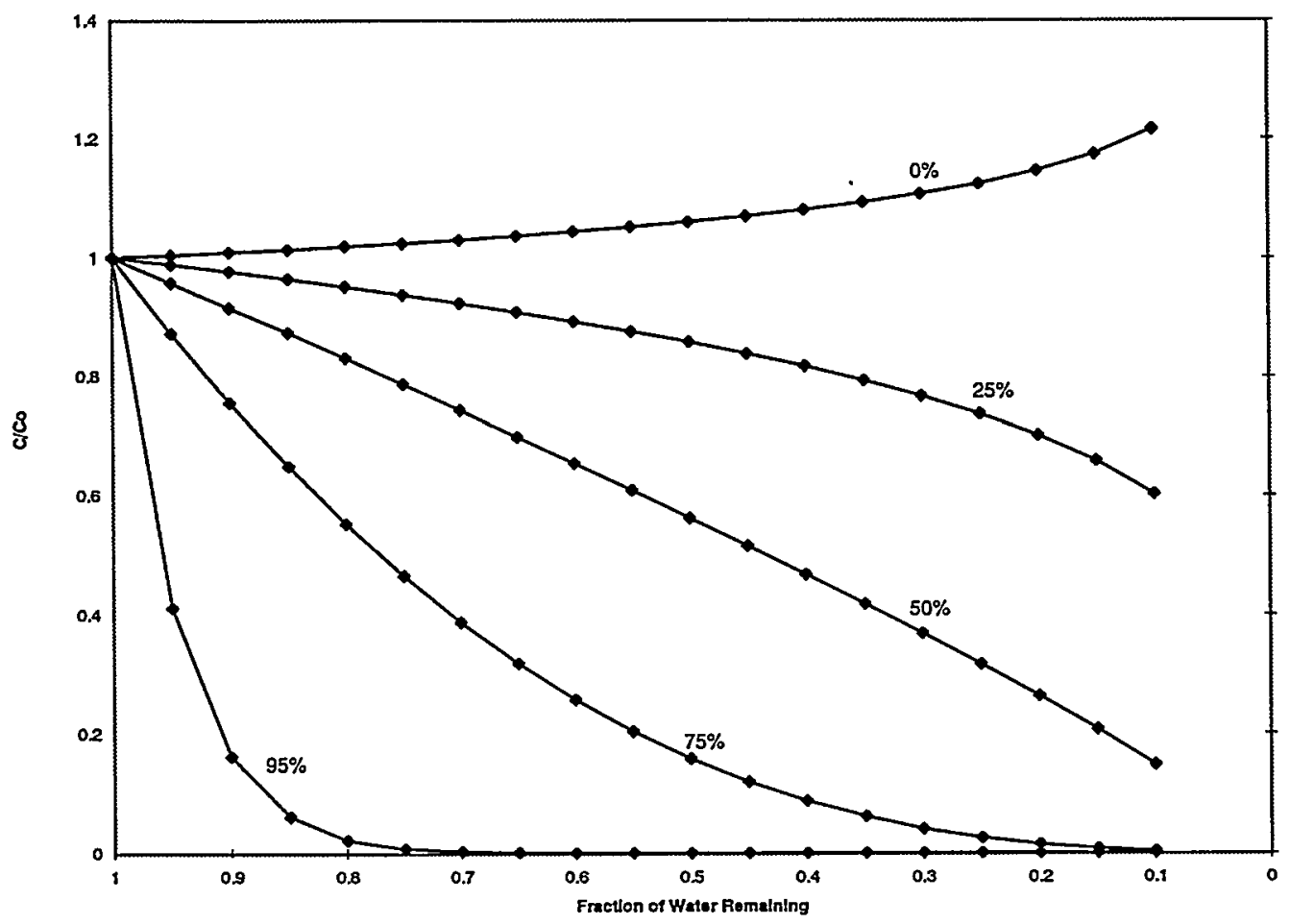

Figure 27. Dimensionless rates of change in tritium activity versus fraction of water remaining for five hypothetical experiments (identical to experiment two) with the sole variation between the experiments being differing levels of relative humidity.

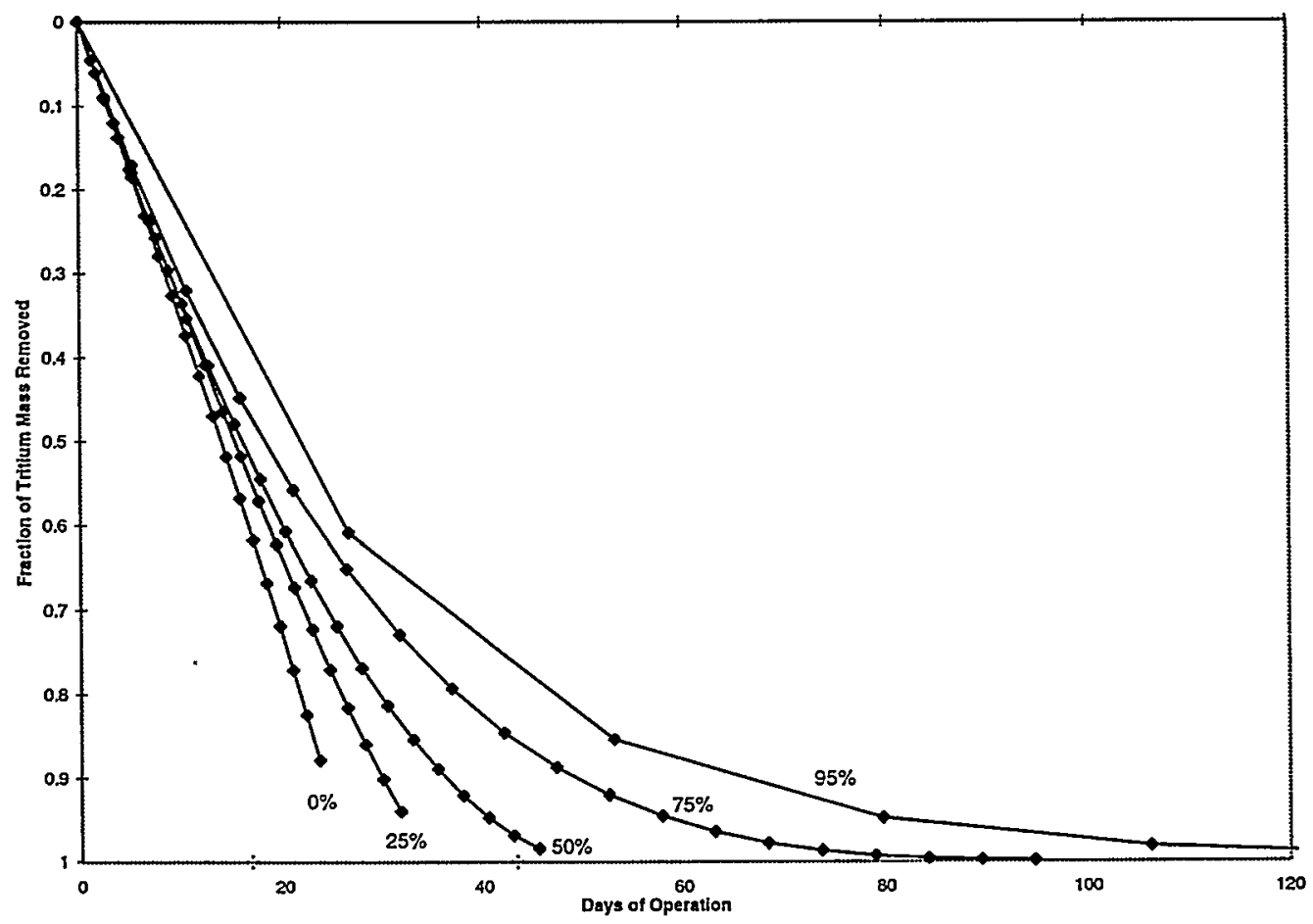

Figure 28. Rates of change in tritium mass within the experimental tank versus time for five hypothetical experiments (identical to experiment two) with the sole variation between the experiments being differing levels of relative humidity. 
TABLE 6. TRITIUM ACTIVITIES IN THE AIR APPROXIMATELY 1 M ABOVE THE SURFACE OF THE TRITIATED FLUID IN THE TANK.

\begin{tabular}{lcc}
\hline & Experiment One & Experiment Two \\
\hline Week 1 (pCi/L) & 82,400 & 78,300 \\
Week 2 (pCi/L) & 124,000 & 36,800 \\
Week 3 (pCi/L) & 133,000 & 24,800 \\
Week 4* $(\mathrm{pCi} / \mathrm{L})$ & 106,000 & 14,800 \\
\hline
\end{tabular}

*Week 4 of Experiment One actually consisted of ten days. Week 4 of Experiment Two consisted of two days.

The experimental results of Slattery and Ingraham (1994) have shown vapor forced through tritiated fluid equilibrates rapidly with the tritium activity of the fluid. Samples taken during the course of experiment one, in which a tarp limited the amount of dilution of the vapor prior to sampling, had activities that were within a factor of two of the tritium activity of the water. Theoretical results indicate that the air directly above the tritiated tank, will have an activity that is approximately 93 percent of that of the tritiated fluid (Slattery and Ingraham, 1994).

The tritiated vapor from the tank emanated as a plume of dense cool tritiated vapor that, under windy conditions, would be thoroughly mixed with the atmosphere and dissipated rapidly and under calm conditions persist for some distance. Figures 8 through 15 presented wind conditions versus tritium activities as a function of azimuth. During the course of the first experiment, the wind was predominantly out of the south to southwest. The highest wind velocities originated from the same direction. Examination of the tritium activities, at $6.1 \mathrm{~m}$, revealed detectable activities in all directions with the majority of the activity being detected generally in the eastern samplers with the highest concentrations ranging between 2,850 to $53,900 \mathrm{pCi} / \mathrm{L}$. At a distance of $30.5 \mathrm{~m}$, the greatest tritium activities were typically sampled towards the east with activities ranging from 1,250 to 4,400 $\mathrm{pCi} / \mathrm{L}$. During the course of the second experiment, the wind most frequently originated from the southwest with the highest velocities occurring from that direction as well. The highest levels of tritium activities, at $30.5 \mathrm{~m}$, were generally detected towards the east and ranged from 15,100 to $3,250 \mathrm{pCi} / \mathrm{L}$. The highest levels of tritium activities, at $6.1 \mathrm{~m}$, were generally detected to the northeast, with activities ranging from 48,900 to $3,690 \mathrm{pCi} / \mathrm{L}$.

A reasonable conclusion is the vapor emanating from the tank was diluted by a factor of 0.5 between the tank and the samplers located at $6.1 \mathrm{~m}$, whereas samples acquired at $30.5 \mathrm{~m}$ were diluted by a minimum factor of 0.1 times the theoretical activity of the vapor exiting the tank. The risk associated with the measured concentrations may be determined utilizing the Lifetime Excess Total Cancer Risk per Unit Uptake or Exposure for a worker breathing 0.833 cubic meters of air per hour for 2000 hours for 40 years. The risk factor is essentially $1 \times 10^{-6}$ for an air vapor tritium activity of $193 \mathrm{pCi}$ per cubic meter of air. Vapor discharging from the initial period of experiment two would have had the highest levels of tritium activity; $4,500 \mathrm{pCi}$ per cubic meter of air. This activity translates to an increase in the Lifetime Excess Total Risk per Unit Uptake of $2.4 \times 10^{-5}$. The maximum observed concentration at $6.1 \mathrm{~m}$, during the course of both experiments, was 53,900 $\mathrm{pCi} / \mathrm{L}$. This observed activity translates to $1,240 \mathrm{pCi}$ per cubic meter of air or an increase in risk of 
$6 \times 10^{-6}$. The maximum observed tritium activity at $30.5 \mathrm{~m}$ was $15,100 \mathrm{pCi} / \mathrm{L}$. This activity is equal to $340 \mathrm{pCi}$ per cubic meter or a risk factor of $1.8 \times 10^{-6}$. The EPA considers a risk of $1 \times 10^{-4}$ to be acceptable, however, their goal for the general public is $1 \times 10^{-6}$.

\section{Extrapolation of Results to Sumps at ER-20-5}

The conditions at the field experiment were designed to allow an evaluation of air sparging as a potential remedial method for the preferential depletion of tritium from the aqueous phase. The experiment at Cambric involved small quantities of fluid with relatively low levels of tritium activity. An assessment of the methodology to a site with realistic volumes of tritiated fluid needs to be conducted.

Well ER-20-5 was drilled in the vicinity of the Tybo underground nuclear detonation. The purpose of the well was to determine the nature and extent of groundwater contamination generated by the detonation. Two wells, ER-20-5\#1 and ER-20-5\#3, were successfully drilled and encountered high levels of tritiated water. Both wells were developed with the water stored in lined pits. A total volume of $3.55 \times 10^{6} \mathrm{~L}$ of fluid with an average activity of $30.4 \times 10^{6} \mathrm{pCi} / \mathrm{L}$ were stored in one of the sumps (sump \#7) adjacent to the well site.

Previous experiments utilized an airflow rate (liters per minute) to water volume (liters) ratio of 1.5. This ratio provides for rapid evaporation of the fluid while minimizing turbulence. If this ratio of air to water were to be preserved, then sump \#7 would require approximately $5.32 \times 10^{6}$ liters of air per minute to be injected into the sump. The source of air at the Cambric experiments was a Gardner Denver cycloblower powered by a Detroit Diesel. This unit, which according to the original invoice, cost $\$ 90,000.00$, was capable of producing 168,000 liters per minute. Approximately 32 of these units would be required to supply the requisite amount of air to remediate sump \#7 at well ER-20-5. If the performance of the blower at the Cambric site was an indicator, then each blower would require approximately 379 L (100 gallons) of diesel every five days.

Figure 29 is a graph of the fraction of tritium removed from sump \#7 at ER-20-5 relative to days of operation required to evaporate that quantity of water as a function of various levels of humidity. It would require approximately 49 days of operation to remove 90 percent of the tritium utilizing 0 percent relative humidity. Injection of air with 0 percent relative humidity would require drying of the air prior to the air being blown into the water. Fifty-six days of operation would be required to remove 90 percent of the tritium at a relative humidity of 25 percent. Sixty-nine days would be required at 50 percent, 93 days at 75 percent, and 125 days of operation at 95 percent humidity. The last three operations would require the use of a humidifier. The most efficient operation would be to operate the system at ambient humidity, which on the NTS, would result in fairly rapid evaporation while still decreasing the concentration of the remaining fluid. An operational period of approximately 65 days, utilizing a relative humidity of 25 percent, would be required to drop the tritium activity of the sump at $\mathrm{ER}-20-5$ to $200,000 \mathrm{pCi} / \mathrm{L}$. This would also result in the evaporation of 98 percent of the fluid. Given enough time, the sumps will naturally evaporate to this quantity of fluid, however, the final tritium activity depends upon the relative humidity of the ambient air. 


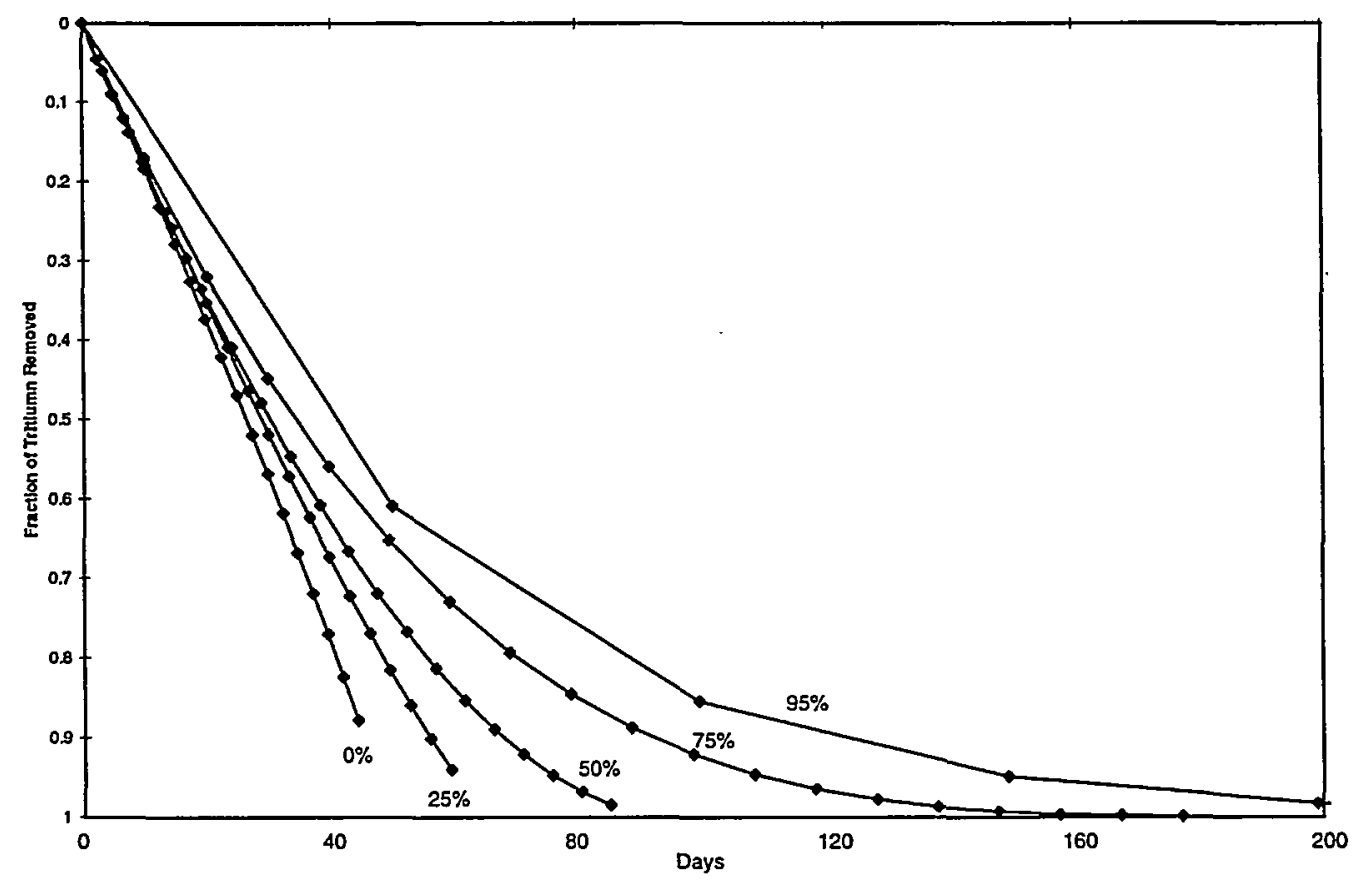

Figure 29. Change in tritium mass versus time for sump \#7 at ER-20-5 as a function of differing levels of relative humidity.

The air sparging of tritium is, due to the large energy requirements to discharge the requisite air into the tritiated fluid, an energy intensive operation. The conduct of this method at one sump at ER-20-5 would require 32 blowers operating for a period of 56 days, utilizing $136,400 \mathrm{~L}$ (36,000 gallons) of diesel to reduce the tritium concentration in that sump by 90 percent. As previously stated, laboratory studies by Wilson (1995) were able to improve efficiencies, as compared to those reported herein, by 30 percent. This was accomplished by utilizing smaller bubbles and longer bubble path lengths over comparable periods of time. Those results, if extrapolated to sumps at ER-20-5, indicate removal of 90 percent of the tritium could be accomplished utilizing 17 blowers operating for only 43 days. Simpler and cheaper methods for moving large quantities of low pressure air may exist. Utilization of these methods would certainly reduce the process to an even more economical one.

A final note is the process is diabatic. The ambient air is compressed and becomes significantly hotter during compression (determined during experiment two to be up to $40^{\circ} \mathrm{C}$ above ambient). Some of this heat is lost as the air travels through the ducts. As the air expands in the tank, it cools to a temperature less than ambient. This cooling was as much as $10^{\circ} \mathrm{C}$ below ambient conditions. The cooling is not desirable, as Slattery and Ingraham (1994) and Wilson (1995) reported an increase in the rate constant as temperature increased. The caution is as the temperature approaches freezing, the tritiated tank would begin to freeze at an ambient temperature greater than $0^{\circ} \mathrm{C}$, halting the exchange process. 


\section{CONCLUSIONS}

Two pilot field-scale studies were conducted during the period of May 24 to July 22, 1996, to evaluate the potential of air sparging to remediate tritiated fluids. Previous analytical solutions to the rate of tritium removal were evaluated and compared to the experimental results. The analytical solution of Craig and Gordon (1965) that describes isotopic fractionation of an evaporating body of water appears to most accurately describe the process, versus the more limited isotopic exchange equation of Slattery and Ingraham (1994) and the mass transfer equation of Wilson (1995) and Fordham (1994) which are accurate only at moderate to high humidities and do not describe the tritium enrichment process that would occur at low humidities.

The results of the two experiments demonstrated that air sparging of tritium is a viable process in the field. Tritium removal rates of 60 percent were reported during the first experiment (duration of 30.89 days) and 66 percent for the second experiment (duration of 22.83 days). Comparison to previous laboratory work revealed that rates could have been improved by starting with higher concentration, utilizing smaller bubbles, and longer bubble path lengths.

Risks associated with the pilot study were greater the closer one worked to the experiment with a maximum increase in the Lifetime Excess Total Risk per Unit Uptake of $2.4 \times 10^{-5}$. Conduct of this experiment to locations with much higher activities of tritium would significantly increase the associated risk.

The air sparging of tritium is, due to the large energy requirements to discharge the requisite air into the tritiated fluid, an energy intensive operation. Simpler and cheaper methods for moving large quantities of low pressure air, other than a blower, may exist. Utilization of these methods may reduce the process to an economical proposition. One such method may be the blowing of ambient air (as long as it is greater than 8 percent relative humidity) across the surface of the ponds containing the tritiated fluid. This cheap alternative would enhance evaporation and reduce the activity of tritium in the aqueous phase, without large expenditures of energy or high maintenance costs.

It is recommended that a full field-scale operation be implemented to evaluate alternative methods of aerating the water. It is also highly recommended that a mechanical and or chemical engineer, preferably one with practical experience in processes involving aeration, be included. The inclusion of an engineer with this experience will allow the optimal aeration process to be developed. This full-scale operation should involve quantities of tritiated water in the millions of liters with activities of millions of $\mathrm{pCi} / \mathrm{L}$. An air monitoring strategy will need to be implemented as the Lifetime Excess Total Cancer Risk per Unit Uptake or Exposure would be $2.9 \times 10^{-3}$ for water with activities of $30.4 \times 10^{6} \mathrm{pCi} / \mathrm{L}$ (sump $\# 7$ at well ER-20-5 contains this activity). Therefore, adequate process and engineering controls will need to be implemented. These would include limiting exposure during operation via minimum safe distances and remote kill switches and adequate buffer areas to allow for safe dilution of the resultant tritiated vapors. 


\section{REFERENCES}

Bolin, B., 1958. On the use of tritium as a tracer for water in nature. Proc. Sec. Intern. Conf. Peaceful Uses of Atomic Energy, Geneva. 18:366.

Craig, H., and L. Gordon, 1965. Deuterium and oxygen-18 in the ocean and marine atmosphere. Spoleto. 165:121.

Dorsey, N. E, 1968. Properties of ordinary water-substance in all its phases: water-vapor, water, and all the ices. Amer. Chem. Soc. Monograph 81.

Dugan, J. P., J. Borthwich, R. S. Harmon, M. A. Gagnier, J. E. Glahn, E. P. Kinsel, S. Macleod, J. A. Viglino and J. W. Hess, 1985. Guanidine hydrochloride method for determination of water oxygen isotopes ratios and the oxygen-18 fractionation between carbon dioxide and water at $25^{\circ}$ C. Anal. Chem. 57:1734-1736.

Environmental Protection Agency, 1975. Handbook of radiochemical analytical methods. U.S. Environmental Protection Agency, National Environmental Research Center, Office of Research and Development, Las Vegas, NV.

Environmental Protection Agency, 1979. Radiochemical analytical procedures for analysis of environmental samples. U.S. Environmental Protection Agency EMSL-LV-0539-17. p. 74-80.

Fordham, S. M., 1994. Removal of tritium from water using tritium free water-saturated air. M.S. Thesis, University of Nevada, Reno.

Friedman, I., L. Machta and R. Soller, 1962. Water-vapor exchange between a water droplet and its environment. Jour. of Geophys. Res. 67:7:2761.

Gonfiantini, R., 1987. Environmental isotopes in lake studies. In Fritz, P., and Fontes, J. Ch. (eds). Handbook of Environmental Isotope Geochemistry. Elsevier Science Publishers. New York, New York.

Harbeck, G.E., M.A. Kohler and G.E. Koberg, 1958. Water-loss investigations, Lake Mead Studies. U.S. Geological Survey Prof. Paper 298. U.S. Geological Survey, Boulder, CO.

Horton, J.H., J.C. Corey and R.M. Wallace, 1971. Tritium loss from water exposed to the atmosphere. Environmental Science and Technology. 5:338-343.

Kendall, C. and T. B. Coplen, 1985. Multisample conversion of water to hydrogen by zinc for stable isotope determination. Anal. Chem. 57:1437-1440.

Kinzer, G. D. and R. Gunn, 1951. The evaporation, temperature, and thermal relaxation time of freely falling water drops. J. Meteorol. 8:71.

Slattery, M.W. and N.L. Ingraham, 1993. Reducing tritium levels in water by low-temperature isotopic exchange of oxygen and hydrogen isotopes between water and water vapor. Desert Research Institute Publication No. 45110. Reno and Las Vegas, NV, 111 p. 
Slattery, M. W. and N. L. Ingraham, 1994. Detritiation of water by isotopic exchange: Experimental results. Environ. Sci. Technol. 28:1417.

Wilson, T.E., 1995. The removal of tritium from contaminated water using aeration. Masters Thesis, University of Nevada, Reno. 69 p. 


\section{DISTRIBUTION}

Bob Bangerter

Environmental Restoration Division

Nevada Operations Office

U.S. Department of Energy

P.O. Box 98518

Las Vegas, NV 89193-8518

Joanne M. Bradbery, Director

Contract Management Division

Nevada Operations Office

U.S. Department of Energy

P.O. Box 98518

Las Vegas, NV 89193-8518

David Bedsun

Defense Special Weapons Agency

Field Command

Nevada Operations Office

P.O. Box 208

Mercury, NV 89023-0208

Mary Lou Brown

International Technology Corporation

4330 S. Valley View

Suite 114

Las Vegas, NV 89103

James Cebe

Energy Technologies Division

Nevada Operations Office

U.S. Department of Energy

P.O. Box 98518

Las Vegas, NV 89193-8518

Frank Di Sanza, Director

Energy Technologies Division

Nevada Operations Office

U.S. Department of Energy

P.O. Box 98518

Las Vegas, NV 89193-8518

Brian Dozier

Bechtel Nevada Corporation

P.O. Box 98521

Las Vegas, NV 89193-8521
Doug Duncan

Hydrology Program Manager

Environmental Protection Division

Nevada Operations Office

U.S. Department of Energy

P.O. Box 98518

Las Vegas, NV 89193-8518

Dennis Farmer

Radiation Sciences Laboratory

Office of Radiation and Indoor Air

U.S. Environmental Protection Agency

P.O. Box 98517 , M/S 513

Las Vegas, NV 89193-8517

Larry Franks

Nevada State Health Department

Radiological Health Section

620 Belrose Avenue

Las Vegas, NV 89158

Joseph M. Ginanni

Waste Management Division

Nevada Operations Office

U.S. Department of Energy

P.O. Box 98518

Las Vegas, NV 89193-8518

Virginia Glanzman

U.S. Geological Survey

Box 2506, MS 913

Denver Federal Center

Denver, CO 80225

Kenneth Hoar, Director

Environmental Protection Division

Nevada Operations Office

U.S. Department of Energy

P.O. Box 98518

Las Vegas, NV 89193-8518

Roger Jacobson

Desert Research Institute

Water Resources Center

P.O. Box 19040

Las Vegas, NV 89132-0040 
Marjory Jones

Desert Research Institute

Water Resources Center

P.O. Box 60220

Reno, NV 89506-0220

Jim Kannard

Bechtel Nevada Corporation

P.O. Box 98521

Las Vegas, NV 89193-8521

Randy Laczniak

U.S. Geological Survey

Water Resources Division

6770 S. Paradise Rd.

Las Vegas, NV 89119

Steve Lawrence

Engineering Division

Nevada Operations Office

U.S. Department of Energy

P.O. Box 98518

Las Vegas, NV 89193-8518

Steve Leedom

Stockpile Stewardship Division

Nevada Operations Office

U.S. Department of Energy

P.O. Box 98518

Las Vegas, NV 89193-8518

Charles E. McWilliam, Director

Defense Projects Division

Nevada Operations Office

U.S. Department of Energy

P.O. Box 98518

Las Vegas, NV 89193-8518

Steve Mellington, Director

Environmental Restoration Division

Nevada Operations Office

U.S. Department of Energy

P.O. Box 98518

Las Vegas, NV 89193-8518
Leslie A. Monroe

Environmental Protection Division

Nevada Operations Office

U.S. Department of Energy

P.O. Box 98518

Las Vegas, NV 89193-8518

Ken Rehfeldt

Geotrans, clo IT

4330 Valley View

Suite 112, MS-439

Las Vegas, NV 89103

Stuart E. Rawlinson

Bechtel Nevada Corporation

P.O. Box 95487, M/S 580

Las Vegas, NV 89193-5487

Monica Salazar-Sanchez

Environmental Restoration Division

Nevada Operations Office

U.S. Department of Energy

P.O. Box 98518

Las Vegas, NV 89193-8518

Ralph Smiecinski

Energy Technologies Division

Nevada Operations Office

U.S. Department of Energy

P.O. Box 98518

Las Vegas, NV 89193-8518

David K. Smith

Isotopes Sciences Division

Lawrence Livermore National Laboratory

P.O. Box 808, M/S L231

Livermore, CA 94550

Michael J. Sully

Bechtel Nevada Corporation

P.O. Box 98521 , M/S 966

Las Vegas, NV 98193-8521

Joe Thompson

Los Alamos National Laboratory

INC-11, MS J514

P.O. Box 1663

Los Alamos, NM 87545 
Doug Trudeau

U.S. Geological Survey

Water Resources Division

6770 S. Paradise Rd.

Las Vegas, NV 89119

Janet Wiley

International Technology Corporation 4330 S. Valley View

Suite 114

Las Vegas, NV 89103

Annie Kelley

State Documents Department

Nevada State Library

Capitol Complex

Carson City, NV 89710

Archives

Getchell Library

University of Nevada, Reno

Beverly Carter

MacKay School of Mines Library

University of Nevada, Reno

Document Section, Library

University of Nevada, Las Vegas

4505 Maryland Parkway

Las Vegas, NV 89154

Library (Stead)

Desert Research Institute

P.O. Box 60220

Reno, Nevada 89506-0220
Library

IT Corporation

4330 S. Valley View

Suite 114

Las Vegas, NV 89103

ATTN: Toni Miller

Library

Southern Nevada Science Center

Desert Research Institute

P.O. Box 19040

Las Vegas, NV 89132-0040

Public Reading Facility

Bechtel Nevada Corporation

P.O. Box 98521

Las Vegas, NV 89193-8521

Technical Information Resource Center

Nevada Operations Office

U.S. Department of Energy

P.O. Box 98518

Las Vegas, NV 89193-8518

Librarian

Water Resources Center Archives

410 O'Brien Hall

University of California

Berkeley, CA 94720-1718

Office of Scientific and Technical Information

U.S. Department of Energy

P.O. Box 62

Oak Ridge, TN 37831-9939 